UNIVERSIDADE DE SÃO PAULO

PROGRAMA DE PÓS-GRADUAÇÃO EM INTERUNIDADES EM ENSINO DE CIÊNCIAS FACULDADE DE EDUCAÇÃO

INSTITUTO DE BIOCIÊNCIAS

INSTITUTO DE FÍSICA

INSTITUTO DE QUÍMICA

THIAGO LUIS SILVA DE OLIVEIRA

Influência dos Propósitos Epistêmicos e das Ações Típicas do professor na promoção da argumentação em aula investigativa de Ciências 


\section{Influência dos Propósitos Epistêmicos e das Ações Típicas do professor na promoção da argumentação em aula investigativa de Ciências}

Dissertação apresentada ao Programa de Pós-Graduação Interunidades em Ensino de Ciências da Universidade de São Paulo para obtenção do Título de Mestre em Ensino de Ciências (modalidade Biologia).

Área de Concentração: Ensino de Ciências e Matemática.

Orientador: Prof. Dr. Marcelo Tadeu Motokane 
Autorizo a reprodução e divulgação total ou parcial deste trabalho, por qualquer meio convencional ou eletrônico, para fins de estudo e pesquisa, desde que citada a fonte.

\section{FICHA CATALOGRÁFICA \\ Preparada pelo Serviço de Biblioteca e Informação do Instituto de Física da Universidade de São Paulo}

Oliveira, Thiago Luis Silva de

Influência dos propósitos epistêmicos e das ações típicas do professor para promoção da argumentação em aula investigativa de ciências. São Paulo, 2016.

Dissertação (Mestrado) - Universidade de São Paulo. Faculdade de Educação, Instituto de Física, Instituto de Química e Instituto de Biociências

Orientador: Prof. Dr. Marcelo Tadeu Motokane

Área de Concentração: Ensino de Biologia

Unitermos: 1. Biologia - Estudo e ensino; 2. Ensino por investigação; 3. Propósitos epistêmicos; 4. Ações típicas; 5. Argumentação.

USP/IF/SBI-056/2016 
Ubiratan e Márcia,

Com Amor 


\section{AGRADECIMENTOS}

Agradeço aos meus pais pela vida e pelas palavras de incentivo durante minha vida acadêmica. Ao meu irmão, obrigado pelas atitudes diplomáticas e palavras gentis. À minha cunhada, pelos minutos de sorrisos. Ao Diego, pelo companheirismo, cuidado e atenção. A sua alegria de viver que me faz feliz.

Ao meu orientador, prof. Dr. Marcelo Tadeu Motokane, por me disponibilizar parte de seu tempo para me acompanhar em minha formação pessoal e profissional. Agradeço-o por me ajudar inúmeras vezes na construção de uma visão de mundo mais comprometida com a honestidade, com a justiça social e com o respeito com os mais desfavorecidos. Agradeço-o também por me encantar com o campo de pesquisa em linguagem e ensino de ciências e por me fazer sorrir nos momentos em que era essencial ser leve.

Aos colaboradores e, acima de tudo, meus grandes amigos: o professor Dr. Marcelo Pereira e o doutorando Caio de Castro Freire pela disponibilização das gravações que formaram os dados e pelas diversas contribuições durante $o$ desenvolvimento de minha pesquisa.

Aos meus companheiros de trabalho do grupo LINCE, hoje amigos: Caio, Rafael, Luziene, Sofia, Teresa, Michele, Brucce, Maurício, Dr. Marcelo Pereira e Dr. Marcelo Tadeu Motokane. Obrigado a todos vocês pelo carinho, atenção, sugestões de alterações no trabalho durante reuniões semanais do LINCE e minutos de café. Meus sinceros agradecimentos.

Às professoras Dra. Daniela Lopes Scarpa e Dra. Mariana Guelero do Valle, pelas preciosas contribuições durante a qualificação.

À USP, pela oportunidade de ingresso e pelo ensino de qualidade compromissada com a melhoria da sociedade.

Ao Programa de Formação de Professores da FEUSP, pela bolsa de monitoreducador durante o meu primeiro ano de pós-graduação, a CAPES pelo financiamento durante o segundo e terceiro ano e, durante o restante do mestrado, ao banco Santander pela bolsa concedida de monitor-educador para realizar atividades no curso de Licenciatura em Ciências no polo de Ribeirão Preto - SP.

Queiram me desculpar os “esquecidos”. Sintam-se também abraçados. 


\section{RESUMO}

\section{OLIVEIRA, T. L. S. Influência dos Propósitos Epistêmicos e das Ações Típicas do}

professor na promoção da argumentação em aula investigativa de Ciências. 2016.

83 f. Dissertação de Mestrado - Universidade de São Paulo, São Paulo, 2016.

A mediação do professor é fundamental para a construção de argumentos em aulas de Ciências. Nesse sentido torna-se importante estudar as interações discursivas entre professor e alunos. O presente trabalho teve por objetivo analisar como os propósitos e as ações do professor estimulam a argumentação dos alunos em uma aula investigativa de ciências. Para caracterizar a mediação do professor foi utilizada a ferramenta analítica "propósitos epistêmicos e ações típicas para promoção da argumentação" de Ferraz e Sasseron (2014) e de Ferraz (2015), enquanto que o layout de Toulmin (TAP) (2006) foi utilizado para identificar os elementos do argumento construídos pelos alunos. Foram identificados dois argumentos contendo os elementos básicos do TAP construídos coletivamente ao longo da aula. Durante a construção dos argumentos, o professor utilizou os propósitos retomar, problematizar, explorar e qualificar. As ações "retoma dado" e "explora ponto de vista" contribuíram para a construção do elemento dado. A construção da garantia deveu-se as ações "retoma conceito", "retoma informações", "explora ponto de vista" e "qualifica variáveis, objetos ou fenômenos". A construção do elemento conclusão foi promovida pela ação "propõe um problema". As ações "qualifica variáveis, objetos ou fenômenos", "qualifica explicações ou pontos de vista", "retoma informações" e "explora ponto de vista" auxiliaram na construção do elemento refutação do TAP. A maior frequência dos propósitos explorar e qualificar deveu-se ao esforço do professor em promover a avaliação de dados e garantias que os alunos estavam utilizando para a construção de suas conclusões sobre a presença ou não de seres vivos na amostra analisada.

Palavras-chave: Biologia - Estudo e ensino; Ensino por investigação; Propósitos epistêmicos; Ações Típicas; Argumentação. 


\section{ABSTRACT}

OLIVEIRA, T. L. S. The influence of epistemic purposes and typical actions of the teacher to promote argumentation in inquiry science class. 2016.83 p. Masters Dissertation - Universidade de São Paulo, São Paulo, 2016.

The mediation of the teacher is fundamental for the construction of arguments in science class. Like this it is important to study the discursive interactions between teacher and students. This study aimed to analyze how the teacher's purposes and actions stimulate the reasoning of students in an inquiry science class. The analytical tool "epistemic purpose and typical actions to promote the argumentation" (FERRAZ; SASSERON, 2014; FERRAZ, 2015) was used to characterize the mediation of the teacher while the Toulmin Argument Pattern (TAP) (2006) was used to identify argument elements built by students. Two arguments containing the basic elements of TAP collectively built along class were identified. During the construction of the arguments, the teacher used the purpose resume, problematize, explore and qualify. The actions "given recovery" and "explores view" contributed to the construction of the data element. The construction of the warrants was due to the actions "recovery concept", "recovery information", "explores points of view" and "qualifies variables, objects or phenomena". The construction element conclusion was promoted by the action "proposes the problem". The actions "qualifies variables, objects or phenomena", "qualifies explanations or points of view", "recovery information" and "explores perspective" helped in the construction of refutation element of TAP. The highest frequency of the purposes explore and qualify was due to the teacher's effort to promote the evaluation of data and warrants that students were using to build its conclusions on the presence or absence of living organisms in the sample.

Key-words: Biology - Study and Teaching; Inquiry-based Science Teaching; Epistemic purposes; Typical Actions; Argumentation. 


\section{SUMÁRIO}

APRESENTAÇÃO

INTRODUÇÃ

CAPÍTULO 1 - O PAPEL DO PROFESSOR NA CONSTRUÇÃo DE INTERAÇÕES DISCURSIVAS EM AULAS INVESTIGATIVAS DE CIÊNCIAS

1.1. O ENSINO DE CIÊNCIAS POR INVESTIGAÇÃO E SEQUÊNCIAS DIDÁTICAS INVESTIGATIVAS (SDI)

1.2. A CONSTRUÇÃO DE INTERAÇÕES DISCURSIVAS EM AULAS DE CIÊNCIAS: UM PANORAMA SOBRE FERRAMENTAS DE ANÁLISE DA MEDIAÇÃO DO PROFESSOR

1.3. O PROFESSOR E A CONSTRUÇÃO DE UM ESPAÇO INTERATIVO DE ARGUMENTAÇÃO COLABORATIVA: PROPÓSITOS EPISTÊMICOS E AÇÕES TÍPICAS 32

CAPÍTULO 2 - ARGUMENTAÇÃo NAS AULAS DE CIÊNCIAS 34

2.1. CONCEITO E IMPORTÂNCIA DA ARGUMENTAÇÃO NAS AULAS DE CIÊNCIAS34 2.2. COMPONENTES DO ARGUMENTO: O LAYOUT DE TOULMIN (TAP), 36

2.3. OS USOS E AS LIMITAÇÕES DO TAP EM PESQUISAS EM ENSINO DE CIÊNCIAS ENVOLVENDO ARGUMENTAÇÃO ORAL DOS ALUNOS 37

CAPÍTULO 3 - METOdOLOGIA 41

3.1. METODOLOGIA DE PESQUISA 41

3.2. CONTEXTO DA PESQUISA 41

3.3. SUJEITOS PARTICIPANTES DA PESQUISA 42

3.4. SEQUÊNCIA DIDÁTICA INVESTIGATIVA (SDI) SOBRE SERES VIVOS . 43

3.5. CONSTRUÇÃO DE DADOS 45

3.6. PROPÓSITOS EPISTÊMICOS E AÇÕES TÍPICAS DO PROFESSOR PARA

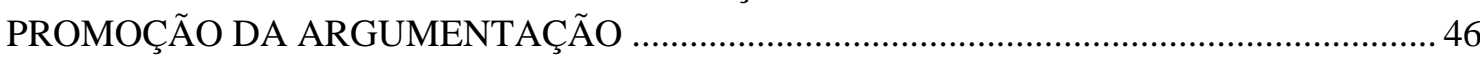

3.7. LAYOUT DE ARGUMENTO DE TOULMIN 47

3.8. TABULAÇÃO: CONSTRUÇÃO E INTERPRETAÇÃO DE TABELAS E GRÁFICOS . 48 CAPÍTULO 4 - RESULTADOS E DISCUSSÃO 50

4.1. PROPÓSITOS EPISTÊMICOS E AÇÕES TÍPICAS PRESENTES NA AULA ..................50 
4.3. RELAÇÕES ENTRE OS PROPÓSITOS EPISTÊMICOS E AÇÕES TÍPICAS DO PROFESSOR COM OS ELEMENTOS DO TAP DOS ALUNOS ............................................ 55

4.4. CONSIDERAÇÕES FINAIS ................................................................................ 58

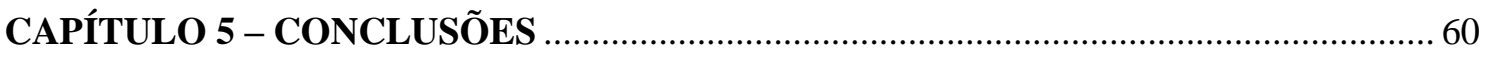

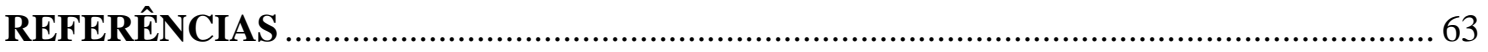

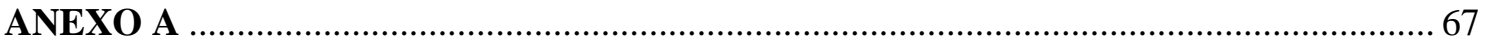

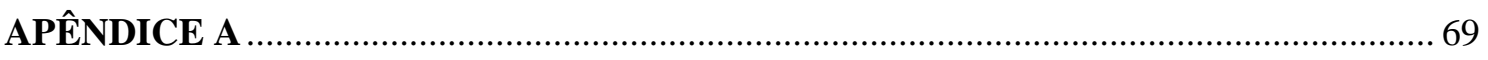

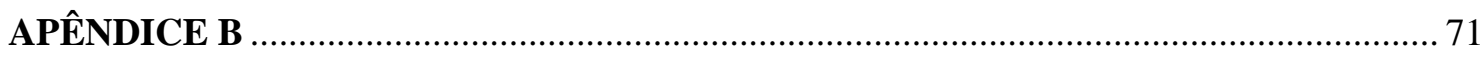

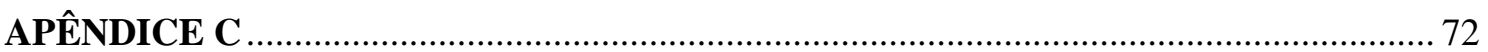




\section{APRESENTAÇÃO}

Iniciei o mestrado no primeiro semestre de 2013. Dediquei o primeiro ano de curso para obter os 42 créditos exigidos pelo Programa de Pós-Graduação Interunidades em Ensino de Ciências da Universidade de São Paulo (PIEC-USP). Além disso, trabalhei como bolsista na Faculdade de Educação (FEUSP) na condição de monitoreducador.

No ano seguinte, comecei a participar das reuniões semanais do grupo LINCE. Tive muitas dificuldades durante essa etapa do mestrado. Descobri que meu estilo de escrita era inadequada para a comunidade acadêmica. Compreender como funcionava a pesquisa em linguagem e ensino de ciências foi o meu segundo desafio. O terceiro grande desafio foi reconhecer a série de ferramentas de análise para atender coerentemente aos dados construídos, a pergunta de pesquisa e aos objetivos do trabalho.

Ao me aproximar dos membros do grupo LINCE (Linguagem e Ensino de Ciências), além da orientação do professor Dr. Marcelo Motokane, tive a disponibilidade de tempo do professor Dr. Marcelo Pereira e de Caio Castro Freire que me auxiliaram tanto na disponibilidade das gravações, e de tempo dedicado por eles à leitura e para correção de meus textos. A eles eu serei eternamente grato. Por isso assumo que a presente dissertação reflete uma produção coletiva, onde houve colaboração do orientador /coordenador do grupo LINCE, dos alunos de graduação e de pós-graduação que, em diversas reuniões, me sugeriram diversas contribuições sobre minhas análises e que permitiu alcançar a entrega do presente trabalho.

A construção dessa pesquisa passou por duas etapas: uma antes e outra depois da qualificação. Tanto o relatório de qualificação quanto a dissertação fez uso de gravações de áudio e vídeo e de textos escritos por alunos participantes do projeto Mais Educação conduzido por Caio Castro Freire e pelo professor Dr. Marcelo Pereira.

A qualificação dedicou-se a discutir se os textos produzidos por alunos do $5^{\circ}$ ano do ensino fundamental I continham argumentos dentro do layout de Toulmin. Um dos critérios para análise foi averiguar qual experimento cada aluno utilizou pra construir seu argumento. Contudo, na qualificação, foram verificadas diversas fragilidades que me fizeram mudar radicalmente o objeto de estudo. 
Após a qualificação, em maio de 2015, eu e o professor Dr. Marcelo Motokane decidimos mudar o foco da investigação. Agora a análise das práticas do professor que auxiliam na argumentação dos alunos. Inicialmente quis fazer uso de uma ferramenta presente no livro da professora Dra. Anna Maria Pessoa de Carvalho, intitulado Ensino de Ciências por Investigação: condições para implementação em sala de aula. A ferramenta produzida pela professora Dra. Lúcia Helena Sasseron era nomeada propósitos e ações epistemológicas do professor para promover a argumentação em sala de aula me despertou interesse porque, dessa forma, poderíamos classificar aquilo que foi falado pelo professor e que estimularia o aluno a argumentar.

Em 01 de Junho de 2015, a professora Dra. Lúcia Helena Sasseron veio a Ribeirão Preto em um evento chamado I Seminário Institucional do PIBID USP Ribeirão Preto. Ela ministrou uma oficina intitulada Alfabetização Científica: percursos teórico-metodológicos de pesquisa. Como tinha lido sobre a ferramenta propósitos e ações epistemológicas do professor para promover argumentação, quis perguntar a ela algo referente sobre esse instrumento. A professora Dra. Lúcia Helena Sasseron me sugeriu olhar outra ferramenta que seu orientando, Arthur Tadeu Ferraz, tinha desenvolvido: propósitos epistêmicos e ações típicas do professor. Além de ser uma ferramenta mais recente, suponho que a sugestão da professora foi também difundir a sua produção acadêmica para que pudesse ser mais explorada e melhorada.

Assim, após contatar Arthur Tadeu Ferraz e ele me disponibilizar sua dissertação e um trabalho onde apresenta sua ferramenta de análise, quis trabalhar com esse instrumento que elucida o propósito (aquilo que é planejado pelo professor) e a ação (aquilo que é executado pelo professor) para estimular argumentação dos alunos. Em seguida, propusemos descrever cada uma das doze ações típicas para formar subcategorias de análise que estariam inclusas em cada um dos seus respectivos propósitos. Em seguida, fizemos uso dos elementos do layout de argumento de Toulmin (TAP) como categorias de análise da fala dos alunos. E por fim, propomos identificar e descrever as possíveis relações entre os propósitos epistêmicos e ações típicas do professor e os elementos do layout de argumentos do Toulmin presentes nas falas dos alunos.

O trabalho foi dividido em seis partes: na introdução apresento as premissas do trabalho, a pergunta e os objetivos da presente investigação. No capítulo 01 discuto o que é e qual a importância do ensino de ciências por investigação e o papel do professor. Consideramos a mediação do professor como algo fundamental para a 
argumentação dos alunos em aulas de Ciências. Assim, apresentamos as ferramentas produzidas para a análise das ações do professor.

No capítulo 02, exploro os conceitos de argumentação e de argumento e como esse processo/produto é fundamental para as aulas de Ciências. Em seguida, apresento o TAP, destacando os limites e possibilidades do uso dessa ferramenta nas pesquisas em ensino de Ciências.

No capítulo 03 me dedico a construir a metodologia para investigação. $\mathrm{O}$ trabalho é uma abordagem qualitativa do tipo estudo de caso. Apresento como foi realizada a transcrição de áudio, a construção de quadros contendo as falas do professor e dos alunos e as ferramentas de análise para classificar respectivas falas. Por fim, foi feita a tabulação de dados em que foi identificada uma interação de um propósito epistêmico e ação típica presente na fala do professor com um elemento do TAP presente na fala do aluno.

No capítulo 04 apresentamos os resultados e análises. Por fim, o capítulo 05 foi dedicado às conclusões e às projeções a partir do presente estudo. 


\title{
INTRODUÇÃO
}

Um dos papéis do ensino de ciências é atuar na formação de cidadãos críticos capazes de opinar em diferentes questões presentes na sociedade. De acordo com Chassot (2000, p. 27):

\begin{abstract}
A nossa responsabilidade maior no ensinar Ciências é procurar que nossos alunos e alunas se transformem, com o ensino que fazemos, em homens e mulheres mais críticos. Sonhamos que, com o nosso fazer Educação, os estudantes possam tornar-se agentes de transformação - para melhor - do mundo em que vivemos (CHASSOT, 2000, p. 27).
\end{abstract}

A formação de cidadãos críticos capazes de resolver problemas é um dos objetivos da alfabetização científica (LAUGKSCH, 2000; AULER, 2003; SASSERON, CARVALHO, 2008, 2011). A alfabetização científica (AC) é definida como um processo pelo qual a cultura científica adquire significados, permitindo aos indivíduos tomar decisões políticas e sociais apoiados em conhecimento científico, assim como reconhecer os fenômenos da ciência e tecnologia como parte de seu mundo (BRANDI; GURGEL, 2002; AULER; DELIZOICOV, 2001; LORENZETTI; DELIZOICOV, 2001).

É preciso que o aluno se aproprie das ferramentas culturais das ciências, entendendo suas formas de produzir, legitimar e divulgar conhecimento por meio de uma linguagem específica, dotada de regras e valores próprios (JIMÉNEZALEIXANDRE; AGRASO, 2006). Não se trata apenas do uso de fórmulas e termos técnicos, mas de práticas sociais que configuram um novo modo de pensar e ver a realidade (LAHORE, 1993).

É importante conhecer os eixos estruturantes da alfabetização científica para idealizar, planejar e analisar propostas de um ensino preocupado com a formação de cidadãos nesta perspectiva. Segundo Sasseron e Carvalho, (2008, p. 335)

$\mathrm{O}$ primeiro dos eixos estruturantes refere-se à compreensão básica de termos, conhecimentos e conceitos científicos fundamentais e a importância deles reside na necessidade exigida em nossa sociedade de se compreender conceitos-chave como forma de poder entender até mesmo pequenas informações e situações do dia-a-dia. O segundo eixo preocupa-se com a compreensão da natureza da ciência e dos fatores éticos e políticos que circundam sua prática, pois, em nosso cotidiano, sempre nos defrontamos com informações e conjunto de novas circunstâncias que nos exigem reflexões e análises considerando-se o contexto antes de proceder. Deste modo, tendo em mente a forma como as investigações científicas são realizadas, podemos encontrar subsídios para o exame de problemas do dia-a- 
dia que envolvam conceitos científicos ou conhecimentos advindos deles. $\mathrm{O}$ terceiro eixo estruturante da alfabetização científica compreende o entendimento das relações existentes entre ciência, tecnologia, sociedade e meio-ambiente e perpassa pelo reconhecimento de que quase todo fato da vida de alguém tem sido influenciado, de alguma maneira, pelas ciências e tecnologias. Neste sentido, mostra-se fundamental de ser trabalhado quando temos em mente o desejo de um futuro saudável e sustentável para a sociedade e o planeta (SASSERON; CARVALHO, 2008, p. 335).

O ensino de Ciências baseado nesses eixos estruturantes pode contribuir para a autonomia e a criticidade dos alunos frente a contextos sociais plurais em constante processo de mudança, impulsionados pela ciência e tecnologia (VIECHENESKI; CARLETTO, 2011). A AC é um objetivo do ensino de Ciências e o ensino por investigação é uma das formas de promovê-la. O ensino por investigação é uma abordagem didática, cujo papel do professor é levar os alunos a discutir sobre fenômenos naturais, a buscar resoluções de um problema de natureza científica, além de exercitar práticas e raciocínios de comparação, de análise e de avaliação, bastante utilizadas no fazer científico (SASSERON, 2015). Durante aulas investigativas esperase que o professor gerencie as atividades e as discussões, incentivando os alunos a construir padrões de raciocínio e padrões de linguagem para tornar possível a compreensão de novas ideias (SUTTON, 2003).

Uma das atividades cognitivas que auxiliam o aprendiz a fazer uso de práticas e de ferramentas culturais é a argumentação. A argumentação, no contexto científico, atua como prática para resolução de problemas, seja por meio de uma avaliação crítica dos dados e fenômenos ou pelos debates entre os cientistas. Enquanto elemento estrutural da linguagem científica, a argumentação é essencial para fazer ciência e comunicar afirmações científicas (JIMENEZ-ALEIXANDRE; BUGALLO-RODRÍGUEZ; DUSCHL, 2000).

Devido a seu papel no espaço acadêmico, a argumentação tem sido analisada no contexto de aulas de ciências com o objetivo de associar a atividade do pensamento dos cientistas ao de crianças comuns, adolescentes e adultos (KUHN, 1993).

A prática da argumentação na sala de aula é consistente com os objetivos gerais da educação que visa formar alunos capazes de raciocinar sobre problemas de ordem prática, pragmática, ou baseadas em fontes de diferentes gêneros textuais (JIMENEZALEIXANDRE; BUGALLO-RODRÍGUEZ; DUSCHL, 2000).

A argumentação também permite desenvolver nos alunos um posicionamento crítico frente às questões problematizadoras que envolvam decisões políticas e sociais 
apoiados em conhecimento científico, assim como os fenômenos da ciência e da tecnologia como parte de seu mundo. Afinal, argumentar representa o ato de justificar a adoção de uma conclusão em detrimento de outra, usando dados que atuam como premissas para essa conclusão; é o ato de oferecer evidências necessárias para estabelecer a validade de uma asserção (KUHN, 1993).

Para que a argumentação seja praticada pelos alunos na sala de aula de Ciências, é necessário que o professor construa um espaço interativo de argumentação colaborativa (FERRAZ, 2015). Segundo o autor, o espaço interativo de argumentação colaborativa é um

ambiente em que a argumentação progride conforme o professor medeia interações de diferentes níveis entre seus alunos e dados teóricos e empíricos disponíveis, tornando a construção de argumentos algo colaborativo, conforme são apresentadas explicações ao objeto investigado (FERRAZ, 2015, p. 43).

Para que o professor possa construir um espaço interativo de argumentação colaborativa uma das formas de realizar seria por meio de aulas investigativas de Ciências. A aula investigativa é uma abordagem didática que encontra respaldo na própria epistemologia das ciências e em aspectos da natureza da ciência (SASSERON, 2015). Para Carvalho (2011), a aula investigativa além de introduzir o aluno no universo das ciências para que seja capaz de construir conhecimento, proporciona

\footnotetext{
aos alunos oportunidades para olharem os problemas do mundo elaborando estratégias e planos de ação. Desta forma o ensino de Ciências [por investigação] se propõe a preparar o aluno desenvolvendo, na sala de aula, habilidades que lhes permitam atuar consciente e racionalmente fora do contexto escolar (CARVALHO, 2011, p. 253).
}

Desse modo, ao planejar e ao executar uma aula investigativa, entende-se que a mediação do professor pode auxiliar na iniciação e no desenvolvimento da argumentação dos alunos na sala de aula de Ciências. Reconhecendo-se que a mediação do professor pode ser analisada pelos propósitos epistêmicos e ações típicas (FERRAZ; SASSERON, 2014; FERRAZ, 2015) e a argumentação dos alunos pode ser analisada por meio do layout de argumentos de Toulmin (2006), pergunta-se: Como os propósitos epistêmicos e as ações típicas do professor contribuem para a argumentação oral dos alunos durante uma aula investigativa de ciências? 
O objetivo geral da investigação é relacionar os elementos do argumento de Toulmin presentes nas falas dos alunos com os propósitos epistêmicos e as ações típicas presentes na fala do professor. Os objetivos específicos da pesquisa são:

a) Identificar os propósitos epistêmicos e as ações típicas nas falas do professor durante a realização da aula investigativa nas situações de resolução da atividade;

b) Identificar os elementos do layout de argumentos de Toulmin (TAP) nas falas dos alunos durante a resolução da atividade;

c) Identificar e descrever as possíveis relações entre os propósitos epistêmicos e as ações típicas presentes na fala do professor e a construção dos elementos do TAP encontrados nas falas dos alunos. 


\section{CAPÍtUlO 1 - O PAPEL DO PROFESSOR NA CONSTRUÇÃO DE INTERAÇÕES DISCURSIVAS EM AULAS INVESTIGATIVAS DE CIÊNCIAS}

Neste capítulo são apresentadas bases teóricas relacionadas ao ensino por investigação e as sequências didáticas investigativas (SDI). Em seguida, discutiremos sobre o papel do professor na construção de um espaço interativo de argumentação colaborativa.

\subsection{O ENSINO DE CIÊNCIAS POR INVESTIGAÇÃO E SEQUÊNCIAS DIDÁTICAS INVESTIGATIVAS (SDI)}

Há mais de duas décadas a educação científica tem sido centralizada para fomentar a alfabetização científica (LAUGKSCH, 2000). A National Science Education Standards define uma pessoa alfabetizada cientificamente como alguém que é capaz de "utilizar processos e princípios competentes na tomada de decisões pessoais" e "envolver de forma inteligente no discurso público e em debates sobre assuntos de interesse científico e tecnológico" (NCR, 1996, p. 13). Desse modo, tais afirmações sugerem que os professores devam estimular seus alunos a uma aquisição de conhecimento por meio de uma participação mais ativa.

A promoção da participação ativa dos alunos é um dos objetivos da comunidade de educação científica. Essa promoção pode ocorrer por meio do ensino por investigação ou ensino por descoberta, entre outras designações (SADLER, 2006).

Cabe ao professor a execução de um ensino por investigação, cuja intenção deve possibilitar o aluno a protagonizar a construção de conhecimentos científicos. Para que isso seja possível, o professor deve estimular nos alunos habilidades que ajudem a resolver problemas a eles apresentados, levando-os a interagir com os seus colegas, com os materiais à disposição e com os conhecimentos já sistematizados e existentes (SASSERON, 2015).

Essa abordagem didática incentiva os alunos a se envolverem em alguns elementos da investigação, como o trabalho com as variáveis, delineamento de experimentos e a confirmação de hipóteses. Contudo, normalmente os alunos não conseguem compreender com precisão a prática social da ciência ou promover as competências necessárias para a avaliação e a defesa de teorias científicas ou descobertas (SADLER, 2006). 
Além disso, um programa de educação científica eficaz propõe o desenvolvimento de práticas discursivas que permitem que os alunos apliquem seus entendimentos da ciência para tomar decisões pessoais. Entre as práticas discursivas incluem-se a avaliação de provas, a avaliação de alternativas, o estabelecimento de validades das afirmações científicas e a argumentação científica (DRIVER; NEWTON; OSBORNE, 2000).

Uma das intenções na prática do ensino por investigação é a promoção de situações argumentativas e explicativas. Jimenez-Aleixandre (2007) afirma que a construção de ambientes de aprendizagem que estimulem a argumentação dos alunos é fundamental para a construção do seu próprio conhecimento, seja por meio da relação entre teoria com dados e conclusões, ou pela avaliação de hipóteses alternativas, todas elas práticas requeridas no discurso científico.

A execução desse ensino pode ser alcançada por meio de sequências de ensino investigativas (SEIs). Carvalho (2013, p. 9) define

[...] as sequências de ensino investigativas (SEIs), isto é, sequência de atividades (aulas) abrangendo um tópico do programa escolar em que cada atividade é planejada, do ponto de vista do material e das interações didáticas, visando proporcionar aos alunos: condições de trazer seus conhecimentos prévios para iniciar os novos, terem ideias próprias e poder discuti-las com seus colegas e com o professor passando do conhecimento espontâneo ao científico e adquirindo condições de entenderem conhecimentos já estruturados por gerações anteriores (CARVALHO, 2013, p. 9).

Concordando com as ideias de Carvalho (2013), Motokane (2015) propôs as sequências didáticas investigativas (SDI), que são compostas por uma série de atividades que

[...] são programadas para que possam ser realizadas em uma ou duas aulas, e seus produtos são claramente definidos. Quanto a estes, há uma atenção especial às produções de textos escritos que estimulem os alunos a emitirem opiniões e expressarem conceitos científicos. Procura-se, nas aulas, promover momentos que sistematizem informações e encaminhamentos de atividades para as aulas seguintes, bem como retomadas importantes para o desenvolvimento de atividades futuras (MOTOKANE, 2015, p. 119).

As características principais das SDI propostas por Motokane (2015, p. 133-134) são: 
1. A participação ativa do aluno surge como um elemento importante, uma vez que os alunos discutem suas ideias e as dos colegas, propondo problemas e suas resoluções e compartilhando suas impressões de forma livre.

2. As atividades são programadas para que possam ter começo, meio e fim em cada aula, possibilitando fechamentos e sistematizações aula a aula.

3. Os conceitos científicos são foco da aprendizagem e estão declarados de modo explícito para alunos e professores. Esses conceitos são parte do conteúdo programático das escolas, a fim de criar uma identidade da SDI com o trabalho que o professor já realiza. Esse é um item de fundamental importância para estimular o professor a utilizar a SDI em suas aulas.

4. Nas atividades, há produção de textos escritos, que devem ser corrigidos e partilhados em sala de aula. As devolutivas das produções são mediadas pelos professores e fundamentais para a aquisição de elementos da linguagem científica.

5. Muitas atividades também envolvem a leitura de textos, que podem complementar as informações das aulas, sistematizar conhecimentos, promover novas perguntas ou trazer os conteúdos para uma realidade mais próxima da vida do aluno. Algumas atividades de leitura podem, ainda, fundamentar debates e estimular o posicionamento perante uma questão científica ou sociocientífica.

6. Há um problema claro e explícito baseado em problemas da ciência. O ponto de partida das atividades é uma situação problematizadora ou um problema autêntico. Além disso, todos os problemas são passíveis de resolução pelos alunos.

7. Há um conjunto de dados claros para embasar as conclusões. Esses dados podem ser provenientes de atividades experimentais ou teóricas. Tais conclusões devem trazer os dados interpretados.

8. Os alunos recorrem a materiais de apoio de diferentes tipos para construir as justificativas no campo do conhecimento científico. Como as atividades de leitura e escrita são de grande importância para o desenvolvimento das SDIs, é necessário que as informações sejam apresentadas em diferentes suportes, tais como: vídeos, páginas da rede mundial, buscadores de informação, textos impressos, imagens impressas produzidas por diferentes equipamentos, entre outros.

9. As atividades permitem que a linguagem seja modulada pelo professor, para que os alunos utilizem terminologias e conceitos adequados e para que essa utilização seja compartilhada entre os alunos. Ele é o mediador de todas essas produções.

10. Todas as SDIs têm a possibilidade de inclusões e adaptações necessárias para o bom andamento das aulas, respeitando a realidade de cada escola e sala de aula (MOTOKANE, 2015, p. 133-134).

Uma característica marcante nas atividades presentes nas SDIs do grupo LINCE (Linguagem e Ensino de Ciências) coordenado pelo professor Dr. Marcelo Tadeu Motokane é a realização de atividades investigativas que exigem manipulação de materiais simples como lápis e papel e de objetos como um texto, uma imagem, um gráfico, uma tabela. Assim, dependendo da mediação do professor, mesmo os problemas de "lápis e papel" podem dar espaço para desenvolver habilidades como cooperação, concentração, organização e interpretação de informações/dados, levantamento de hipóteses, explicação e argumentação sobre fenômenos. 
Propostas como questionários, alternância entre leitura e discussão de textos, dentre outras intervenções dessa natureza, podem auxiliar na formação de cidadãos empoderados, responsáveis e atuantes em suas tomadas de decisões (SASSERON, 2014).

Neste sentido, solucionar uma atividade investigativa exige o aperfeiçoamento das habilidades de pensamento, que permitem a aquisição de novos conhecimentos. Por esse motivo, tem sido mais estimulado que o aluno "aprenda a aprender", bem como, "aprenda a pensar", de modo que tenha disponíveis os instrumentos necessários para alcançar as metas da alfabetização científica.

A realização de atividades investigativas em sala de aula deve estar envolvida com os propósitos (planejamento) e ações (execuções) do professor. No próximo tópico serão discutidas ferramentas desenvolvidas para classificação das falas do professor durante as interações discursivas com os alunos.

\subsection{A CONSTRUÇÃO DE INTERAÇÕES DISCURSIVAS EM AULAS DE CIÊNCIAS: UM PANORAMA SOBRE FERRAMENTAS DE ANÁLISE DA MEDIAÇÃO DO PROFESSOR}

O discurso em sala de aula é muito mais do que uma conversação. É uma complexa interação entre professores e alunos na qual perspectivas únicas construídas por esses indivíduos se manifestam em comunicações verbais (SMART; MARSHALL, 2012). Mortimer e Scott (2002, p. 284) consideram que as interações discursivas são consideradas como constituintes do processo de construção de significados. Já Sasseron (2013) compreende interação discursiva nas aulas de Ciências como debates entre os pares que permite com que os conhecimentos científicos sejam organizados. A autora destaca que o papel do professor é realizar interações discursivas com os alunos por meio de atividades.

Investigações relacionadas com as ações do professor para promover interações discursivas têm sido trazidas à comunidade de pesquisadores em ensino de ciências por diversos trabalhos. Uma das ferramentas de análise de interações discursivas conhecidas é a de Mortimer e Scott (2002, 2003). O objetivo dessa ferramenta é caracterizar as formas como os professores guiam as interações que resultam na produção de significados nas aulas de Ciências. Os aspectos da análise do papel do professor estão inclusos em termos do foco do ensino, abordagem e ações. Os focos do ensino incluem 
as intenções do professor e o conteúdo. A abordagem ocorre na modalidade comunicativa. Por fim, as ações incluem padrões de interação e as intervenções do professor.

As intenções do professor equivalem à etapa de planejamento da atividade. As descrições são apresentadas a seguir:

- Criando um problema: tem o papel de engajar os estudantes, intelectual e emocionalmente, no desenvolvimento inicial da 'estória científica';

- Explorando a visão dos estudantes: elicita e explora as visões e entendimentos dos estudantes sobre ideias e fenômenos específicos;

- Introduzindo e desenvolvendo a 'estória científica': disponibiliza as ideias científicas (incluindo temas conceituais, epistemológicos, tecnológicos e ambientais) no plano social da sala de aula;

- Guiando os estudantes no trabalho com as ideias científicas, e dando suporte ao processo de internalização: dá oportunidade aos estudantes de falar e pensar com as novas ideias científicas, em pequenos grupos e por meio de atividades com toda a classe. Ao mesmo tempo, dar suporte aos estudantes para produzirem significados individuais, internalizando essas ideias;

- Guiando os estudantes na aplicação das ideias científicas e na expansão de seu uso, transferindo progressivamente para eles o controle e responsabilidade por esse uso: dá suporte aos estudantes para aplicar as ideias científicas ensinadas a uma variedade de contextos e transferir aos alunos controle e responsabilidade pelo uso dessas ideias;

- Mantendo a narrativa: sustentando o desenvolvimento da 'estória científica': provêm comentários sobre o desenrolar da 'estória científica', de modo a ajudar os estudantes a seguir seu desenvolvimento e a entender suas relações com o currículo de ciências como um todo.

Outro componente analisado pela ferramenta é o conteúdo, que está associada ao desenvolvimento da estória científica. Esse critério é categorizado em descrição, explicação e generalização. A descrição envolve enunciados que se referem a um sistema, objeto ou fenômeno, em termos de seus constituintes ou dos deslocamentos espaço - temporais desses constituintes. A explicação envolve importar algum modelo teórico ou mecanismo para se referir a um fenômeno ou sistema específico. E a 
generalização en volve elaborar descrições ou explicações que são independentes de um contexto específico.

O terceiro item é a abordagem comunicativa. Esse conceito é central na ferramenta de Mortimer e Scott $(2002,2003)$ porque fornece a perspectiva sobre como o professor trabalha as intenções e o conteúdo de ensino por meio das diferentes intervenções pedagógicas que resultam em diferentes padrões de interação. Há quatro classes de abordagem comunicativa, que são definidas por meio da caracterização do discurso entre professor e alunos ou entre alunos em termos de duas dimensões: discurso dialógico ou de autoridade; discurso interativo ou não interativo. A natureza da interação do professor pode ocorrer em dois extremos: no primeiro, classificada como abordagem comunicativa dialógica, há mais de uma voz presente durante a construção de ideias. No segundo tipo, conhecida como abordagem comunicativa de autoridade, há apenas uma voz, que, em geral é a do professor. Já os discursos podem ser interativo, no qual ocorre a participação de mais de uma pessoa, e o não interativo, que ocorre com a participação de uma pessoa. Combinando-se as dimensões, formam-se quatro classes de abordagem comunicativas (Quadro 1).

\begin{tabular}{|c|c|c|}
\hline & INTERATIVO & NÃO INTERATIVO \\
\hline DIALÓGICO & $\begin{array}{l}\text { Interativo/Dialógico: professor e } \\
\text { estudantes exploram ideias, } \\
\text { formulam perguntas autênticas e } \\
\text { oferecem, consideram e trabalham } \\
\text { diferentes pontos de vista. }\end{array}$ & $\begin{array}{l}\text { Não interativo/Dialógico: } \\
\text { professor reconsidera, na sua } \\
\text { fala, vários pontos de vista, } \\
\text { destacando similaridades e } \\
\text { diferenças. }\end{array}$ \\
\hline DE AUTORIDADE & $\begin{array}{l}\text { Interativo/de Autoridade: professor } \\
\text { geralmente conduz os estudantes por } \\
\text { meio de uma sequência de perguntas } \\
\text { e respostas, com o objetivo de chegar } \\
\text { a um ponto de vista específico. }\end{array}$ & $\begin{array}{l}\text { Não interativo/de Autoridade: } \\
\text { professor apresenta um ponto de } \\
\text { vista específico. }\end{array}$ \\
\hline
\end{tabular}

Quadro 1. Classes de abordagem comunicativa (MORTIMER; SCOTT, 2002, 2003).

O quarto aspecto relaciona-se com os padrões de interação que emergem na medida em que o professor e os alunos alternam os turnos de fala em sala de aula. $\mathrm{O}$ mais comum é a tríade I-R-A (iniciação do professor, resposta do aluno, avaliação do professor). Contudo, podem ocorrer outros padrões de interação de cadeias não tríadicas como, por exemplo, I-R-F-R-P-R, onde P significa uma ação discursiva de permitir o prosseguimento da fala do aluno e $\mathrm{F}$ um feedback para que o aluno elabore um pouco mais sua fala.

Por fim, a etapa de análise das intervenções do professor é feita seguindo orientações descritas no quadro seguinte (Quadro 2). 


\begin{tabular}{|c|c|c|}
\hline $\begin{array}{l}\text { INTERVENÇÃO DO } \\
\text { PROFESSOR }\end{array}$ & FOCO & AÇÃO DO PROFESSOR \\
\hline $\begin{array}{l}\text { 1. Dando forma aos } \\
\text { significados }\end{array}$ & \multirow{3}{*}{$\begin{array}{l}\begin{array}{l}\text { Explorar as ideias dos } \\
\text { estudantes; }\end{array} \\
\begin{array}{l}\text { Trabalhar os significados no } \\
\text { desenvolvimento da estória } \\
\text { científica. }\end{array}\end{array}$} & $\begin{array}{l}\text { Introduzir um termo novo; } \\
\text { parafraseia uma resposta do } \\
\text { estudante; mostra a diferença } \\
\text { entre dois significados. }\end{array}$ \\
\hline $\begin{array}{ll}\text { 2. } & \begin{array}{l}\text { Selecionando } \\
\text { significados }\end{array}\end{array}$ & & $\begin{array}{l}\text { Considera a resposta do } \\
\text { estudante na sua fala; ignora a } \\
\text { resposta de um estudante. }\end{array}$ \\
\hline $\begin{array}{l}\text { 3. Marcando significados } \\
\text { chaves }\end{array}$ & & $\begin{array}{l}\text { Repete um enunciado; pede aos } \\
\text { estudantes que repita um } \\
\text { enunciado; estabelece uma } \\
\text { sequência I-R-A com um } \\
\text { estudante para confirmar uma } \\
\text { ideia; usa um tom de voz } \\
\text { particular para realçar certas } \\
\text { partes do enunciado. }\end{array}$ \\
\hline $\begin{array}{l}\text { 4. Compartilhando } \\
\text { significados }\end{array}$ & $\begin{array}{l}\text { Tornar os } \\
\text { disponíveis para todos os } \\
\text { estudantes da classe. }\end{array}$ & $\begin{array}{l}\text { Repete a ideia de um estudante } \\
\text { para toda a classe; pede a um } \\
\text { estudante que repita um } \\
\text { enunciado para a classe; } \\
\text { compartilha resultados dos } \\
\text { diferentes grupos com toda a } \\
\text { classe; pede aos estudantes que } \\
\text { organizem suas ideias ou dados } \\
\text { de experimentos para relatarem } \\
\text { para toda a classe. }\end{array}$ \\
\hline $\begin{array}{ll}5 . & \text { Checando } \\
\text { entendimento } \\
\text { estudantes }\end{array}$ & $\begin{array}{l}\text { Verificar que significados estão } \\
\text { atribuídos } \mathrm{em} \text { situações } \\
\text { específicas. }\end{array}$ & $\begin{array}{l}\text { Pede a um estudante que } \\
\text { explique melhor sua ideia; } \\
\text { solicita aos estudantes que } \\
\text { escrevam suas explicações; } \\
\text { verifica se há consenso da classe } \\
\text { sobre determinados significados. }\end{array}$ \\
\hline $\begin{array}{l}\text { 6. Revendo o progresso } \\
\text { da estória científica }\end{array}$ & $\begin{array}{l}\text { Recapitular } \\
\text { significados. }\end{array}$ & $\begin{array}{l}\text { Sintetiza os resultados de um } \\
\text { experimento particular; } \\
\text { recapitula as atividades de uma } \\
\text { aula anterior; revê o progresso } \\
\text { no desenvolvimento da estória } \\
\text { científica até então. }\end{array}$ \\
\hline
\end{tabular}

Quadro 2. Formas de intervenção pedagógica, especificando o foco e as ações do professor (MORTIMER; SCOTT, 2002, 2003).

Outra ferramenta de análise da ação do professor são os movimentos epistemológicos (LIDAR; LUNDQVIST; OSTMAN, 2006). Os movimentos epistemológicos indicam a maneira como o professor instrui os alunos quanto à obtenção adequada do conhecimento.

Uma das motivações que levaram à construção dessa ferramenta foi averiguar como, por exemplo, professores e alunos fazem generalizações a partir de um experimento ou como relacionam descobertas empíricas com questões teóricas e com o mundo que os cerca. Essas e outras questões epistemológicas são relacionadas com a natureza e os processos de construção do conhecimento, que estão ligados à questão 
geral sobre a relação entre o próprio conhecimento e o mundo. Tais questões centrais estão no cerne de como os alunos e os professores devem agir em sala de aula de ciências (LIDAR; LUNDQVIST; OSTMAN, 2006).

As categorias se voltam para as ações do professor, relacionando-as com a epistemologia prática dos alunos. Ou seja, à forma como estes, em suas atividades práticas, consideram o que conta como conhecimento relevante e os meios adequados de obtê-lo (SILVA, 2015).

A seguir, descrevemos os movimentos epistemológicos desenvolvidos no estudo realizado pelos pesquisadores supracitados:

- Confirmação: confirma que os estudantes estão reconhecendo o fenômeno correto ou estão fazendo a válida experiência, concordado com o que os estudantes dizem ou fazem;

- Reconstrução: faz com que os estudantes prestem atenção para fatos que eles já observaram, mas não perceberam como válido;

- Instrução: dá aos estudantes uma direta e concreta instrução sobre como eles devem agir;

- Generalização: capacita os alunos a gerar explicações. O professor sumariza o que no experimento é um fato importante a ser dada atenção;

- Reorientação: demanda que os estudantes tomem outra orientação que aquela que eles iniciaram.

Simon, Erduran e Osborne (2006) publicaram o trabalho Learning to Teach Argumentation: Research and Development in the Science Classroom que discute o papel de compreensão conceitual, epistêmico, cognitivo e metassocial dos alunos por meio da prática da argumentação. Os autores analisam as formas que o professor pode se apropriar do discurso argumentativo e, propor em sala de aula, tarefas que requerem discussão e debates para envolver seus alunos na construção de argumentos.

Para que essa análise fosse possível, os autores supracitados criaram uma ferramenta analítica conceituada como Códigos e Categorias para Processos de Argumentação (Quadro 3). 


\begin{tabular}{|c|c|c|}
\hline $\begin{array}{c}\text { CATEGORIAS DE } \\
\text { PROCESSOS } \\
\text { ARGUMENTATIVOS } \\
\text { REFLETIDOS NAS } \\
\text { INTERAÇÕES DO } \\
\text { PROFESSOR }\end{array}$ & DESCRIÇÃO & $\begin{array}{l}\text { CÓDIGOS PARA AS } \\
\text { INTERAÇÕES QUE } \\
\text { REFLETEM OS OBJETIVOS } \\
\text { DA ARGUMENTAÇÃO }\end{array}$ \\
\hline \multirow{2}{*}{ Falar e escutar } & \multirow{2}{*}{$\begin{array}{l}\text { Com finalidade de que a } \\
\text { argumentação ocorra, os alunos } \\
\text { precisam ser capazes de trabalhar em } \\
\text { grupos, ouvir uns aos outros e } \\
\text { articular suas próprias ideias. } \\
\text { Quando este processo não é } \\
\text { familiarizado pelos alunos cabe ao } \\
\text { professor dirigir a estratégia. }\end{array}$} & Encoraja a escutar \\
\hline & & Encoraja a discussão \\
\hline \multirow{2}{*}{$\begin{array}{c}\text { Sabendo o significado de } \\
\text { argumento }\end{array}$} & \multirow{2}{*}{$\begin{array}{l}\text { É a tentativa que o professor faz para } \\
\text { que o aluno saiba o que significa } \\
\text { argumento e exemplifica. Por meio } \\
\text { de uma reflexão sobre o processo de } \\
\text { argumentação os professores } \\
\text { também podem apontar para } \\
\text { desenvolver uma compreensão do } \\
\text { significado de argumento. }\end{array}$} & Define argumento \\
\hline & & Exemplifica argumento \\
\hline \multirow{3}{*}{ Posicionamento } & \multirow{3}{*}{$\begin{array}{l}\text { A fim de que a argumentação possa } \\
\text { prosseguir, é preciso haver o } \\
\text { reconhecimento de que há diferentes } \\
\text { posicionamentos que pode levar } \\
\text { alguém a ter uma conclusão. Os } \\
\text { professores então devem incentivar a } \\
\text { construção de ideias para que os } \\
\text { alunos sejam capazes de se } \\
\text { posicionar. }\end{array}$} & Encoraja ideias \\
\hline & & Encoraja posicionamentos \\
\hline & & $\begin{array}{l}\text { Valoriza diferentes } \\
\text { posicionamentos }\end{array}$ \\
\hline \multirow{6}{*}{ Justificar com evidência } & \multirow{6}{*}{$\begin{array}{l}\text { As tentativas do professor para } \\
\text { melhorar o processo de justificação é } \\
\text { uma das metas que devem estar } \\
\text { inclusa em sua prática. Os } \\
\text { professores podem falar sobre as } \\
\text { fontes pela qual se originou a } \\
\text { evidência, bem como apresentar as } \\
\text { evidências como resposta para os } \\
\text { estudantes. Além disso, os } \\
\text { professores podem estimular mais a } \\
\text { justificação dos alunos para que se } \\
\text { agreguem às suas conclusões. }\end{array}$} & Checa evidência \\
\hline & & Fornece evidência \\
\hline & & Estimula o uso de justificativa \\
\hline & & Enfatiza a justificativa \\
\hline & & $\begin{array}{c}\text { Encoraja aprimoramento de } \\
\text { justificativa }\end{array}$ \\
\hline & & Faz de advogado do diabo \\
\hline \multirow[t]{2}{*}{ Construir argumentos } & \multirow{2}{*}{$\begin{array}{l}\text { Dentre as várias formas de se } \\
\text { construir argumentos os professores } \\
\text { podem incentivar os alunos a } \\
\text { escrever em quadros. }\end{array}$} & $\begin{array}{c}\text { Utiliza ou disponibiliza } \\
\text { exemplos escritos }\end{array}$ \\
\hline & & $\begin{array}{c}\text { Oferece/apresenta posturas a } \\
\text { serem seguidas }\end{array}$ \\
\hline \multirow{4}{*}{ Avaliar argumentos } & \multirow{4}{*}{$\begin{array}{l}\text { Os professores podem ter metas } \\
\text { claras que incidem na avaliação dos } \\
\text { argumentos dos alunos. Assim, o } \\
\text { docente pode pedir que os alunos } \\
\text { julgue os argumentos, enfatizando se } \\
\text { tem ou não evidência ou então focar } \\
\text { na natureza das provas. Assim, } \\
\text { quando se classifica bons } \\
\text { argumentos como argumentos que } \\
\text { usam provas, esse enunciado foi } \\
\text { codificado para avaliar argumento. } \\
\text { Ao avaliar a natureza da prova, pode } \\
\text { se classificar como argumento forte }\end{array}$} & Encoraja avaliação \\
\hline & & Avalia argumentos \\
\hline & & Processo - usa evidências \\
\hline & & $\begin{array}{c}\text { Conteúdo - natureza da } \\
\text { evidência }\end{array}$ \\
\hline
\end{tabular}




\begin{tabular}{|c|c|c|}
\hline & $\begin{array}{l}\text { porque fez uso adequado dos } \\
\text { conteúdos. }\end{array}$ & \\
\hline \multirow{2}{*}{$\begin{array}{c}\text { Contra } \\
\text { argumentar/debater }\end{array}$} & \multirow{2}{*}{$\begin{array}{l}\text { Embora os professores enfatizem e } \\
\text { encorajem o processo de utilização } \\
\text { de provas, nem todos podem fazer o } \\
\text { mesmo. Assim, cabe o professor a } \\
\text { estimular uma posição oposta a fim } \\
\text { de fazer os alunos à contra } \\
\text { argumentar. }\end{array}$} & $\begin{array}{c}\text { Encoraja a antecipação a contra- } \\
\text { argumentos }\end{array}$ \\
\hline & & Encoraja o debate \\
\hline \multirow{2}{*}{$\begin{array}{c}\text { Refletir sobre o processo } \\
\text { argumentativo }\end{array}$} & \multirow{2}{*}{$\begin{array}{l}\text { É importante incentivar os alunos } \\
\text { sobre o processo de argumentação. } \\
\text { Envolve retomar os processos de } \\
\text { posicionamento, de avaliação e de } \\
\text { contra argumentação incorporando a } \\
\text { ideia central de que é legítimo alterar } \\
\text { uma posição e construir um } \\
\text { argumento oposto. }\end{array}$} & Encoraja reflexão \\
\hline & & $\begin{array}{l}\text { Pergunta sobre mudança de } \\
\text { opinião }\end{array}$ \\
\hline
\end{tabular}

Quadro 3. Códigos e categorias para Processos de Argumentação (SIMON; ERDURAN; OSBORNE, 2006).

Leitão (2011) considera que a argumentação favorece a reflexão e a produção de conhecimento. Assim, a autora apontou tipos de ações discursivas que favorecem o surgimento de argumentação ao converterem 'temas curriculares' em 'temas de argumentação'. Essa ferramenta é agrupada em três categorias gerais: as que criam condições para surgimento da argumentação (plano pragmático); as que sustentam e expandem a argumentação (plano argumentativo) e; as que legitimam o conhecimento construído na argumentação (plano epistêmico).

As ações em nível pragmático são ações que dão permissão para os diferentes pontos de vista e criam condições necessárias para que a argumentação ocorra. Comum a essas ações é que cada uma delas pode ser vista como 'convite à argumentação', que pode ser expandida e explorada, em maior ou menor grau, a depender das condições imediatas da sala de aula, as ações propriamente argumentativas poderão ser realizadas, gerando e sustentando a argumentação. Por fim, as ações epistêmicas que são ações discursivas que trazem para o discurso informações, conceitos, definições pertinentes ao tema focalizado e/ou implementam procedimentos e modos de raciocínios típicos do campo do conhecimento em questão. A seguir, ilustramos as ações discursivas que favorecem a construção da argumentação em sala de aula segundo Leitão (2011) (Quadro 4).

\begin{tabular}{|c|ll|}
\hline TIPOS DE AÇÕES DISCURSIVAS & \multicolumn{1}{c|}{ AÇÕES DISCURSIVAS } \\
\hline Pragmático & 1) & Desafiar os alunos a formularem pontos de vista; \\
& 2) & Pedir aos alunos que justifiquem seus pontos de \\
& vista; \\
& 3) & Colocar o aluno na posição de oponente; \\
\hline
\end{tabular}




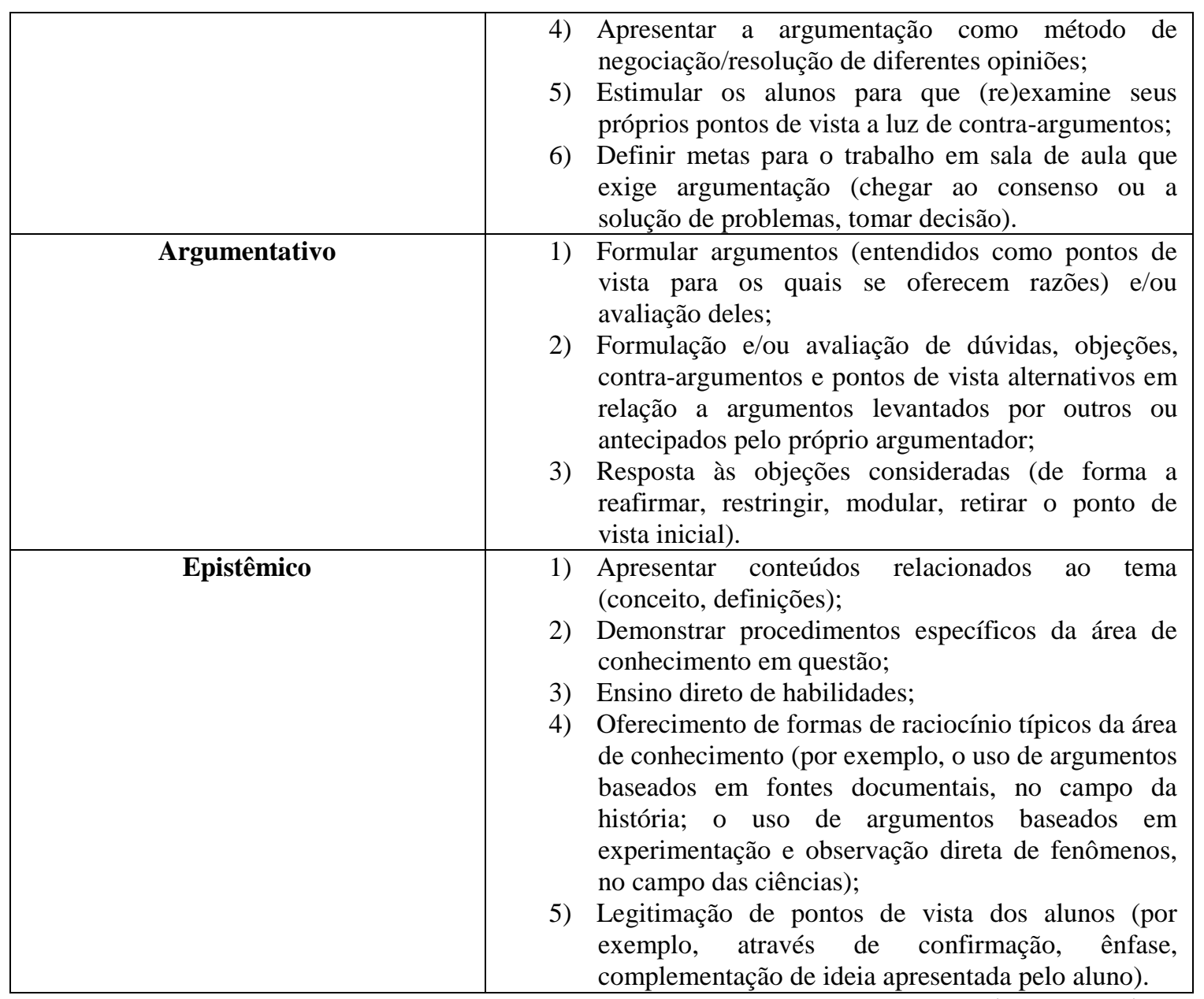

Quadro 4. Ações discursivas que favorecem o surgimento da argumentação nos níveis pragmático, argumentativo e epistêmico (LEITÃO, 2011).

Silva (2015) propôs o conceito de movimentos epistêmicos, cuja definição seria também identificar as ações dos professores ao conduzir aulas investigativas. Os movimentos epistêmicos

referem-se, portanto, às intervenções do professor nas atividades investigativas de um grupo de alunos, que podem ser percebidas como questionamentos, sugestões e orientações significativas para o seu avanço intelectual, favorecendo a adoção de determinadas práticas epistêmicas (SILVA, 2015, p. 73).

As categorias analíticas elaboradas foram as seguintes:

- Elaboração: corresponde às ações do professor que possibilitam aos alunos, em geral por meio de questionamentos, construir um olhar inicial sobre o fenômeno.

São os questionamentos expressos nos roteiros de atividade ou mesmo proferidos oralmente pelo professor, os quais geram espaço para que os alunos 
reflitam segundo determinada perspectiva e exponham seus pontos de vista sobre os objetos e os eventos investigados;

- Reelaboração: corresponde às ações do professor que instigam os alunos, por questionamentos ou breves afirmações, a observarem aspectos desconsiderados ou a trazerem à tona novas ideias, favorecendo uma modificação ou uma problematização do pensamento inicial apresentado;

- Instrução: quando o professor apresenta explicitamente novas informações para os alunos;

- Confirmação: quando o professor concorda com as ideias apresentadas pelos alunos e/ou permite que eles executem determinados procedimentos planejados;

- Correção: quando o professor corrige explicitamente as afirmações e os procedimentos dos alunos;

- Síntese: quando o professor explicita as principais ideias alcançadas pelos alunos;

- Compreensão: quando o professor busca apenas compreender por meio de questionamentos determinados procedimentos e ideias apresentadas pelos alunos.

Um espectro de propósitos e ações do professor fundamentais para promover alguns indicadores de alfabetização científica é apresentado por Sasseron (2013). A proposta apresenta alguns passos metodológicos da investigação científica, como o trabalho com os dados, levantamento e teste de hipóteses, reconhecimento e explicação de variáveis relevantes para o problema em foco, proposição de justificativas e argumentação para resolução do problema; debate de ideias (SASSERON, 2013).

O quadro a seguir (Quadro 5), apresenta de modo sintético os propósitos e ações epistemológicos do professor para promover argumentação em aulas investigativas no ensino de Ciências.

\begin{tabular}{|c|c|}
\hline \multicolumn{2}{|c|}{$\begin{array}{l}\text { PROPÓSITOS E AÇÕES EPISTEMOLÓGICAS DO PROFESSOR PARA PROMOVER } \\
\text { ARGUMENTAÇÃO }\end{array}$} \\
\hline $\begin{array}{c}\text { PROPÓSITOS EPISTEMOLÓGICOS DO } \\
\text { PROFESSOR }\end{array}$ & $\begin{array}{c}\text { AÇÕES EPISTEMOLÓGICAS DO } \\
\text { PROFESSOR } \\
\end{array}$ \\
\hline Retomada de ideias & $\begin{array}{l}\text { Referência a ideias previamente trabalhadas e/ou } \\
\text { experiências prévias dos alunos. }\end{array}$ \\
\hline Proposição de problema & Problematização de uma situação. \\
\hline Teste de ideias & Reconhecimento e teste de hipóteses. \\
\hline Delimitação de condições & $\begin{array}{l}\text { Descrição, nomeação e caracterização } \\
\text { fenômeno e/ou objeto. }\end{array}$ \\
\hline Recor & Delimitação e explicitação de variáveis. \\
\hline Correlação de variáveis & Construção de relações entre variáveis, construção \\
\hline
\end{tabular}


Quadro 5. Propósitos e ações epistemológicas do professor para aulas investigativas no ensino de Ciências. Extraído de Sasseron (2013, p. 50).

As relações entre propósitos e ações epistemológicas (SASSERON, 2013, p. 50-

51) são discutidas a seguir:

1) Retomada de ideias: é uma estratégia para o levantamento de informações que funcionarão como alicerce para as discussões que vão ocorrer e nisso reside sua importância. É uma maneira de o professor iniciar o trabalho de organização de informações e tomada de consciência sobre dados à disposição.

2) Proposição de um problema: uma vez que materiais, dados ou informações já fazem parte do conhecimento dos alunos, a proposição de um problema atua como propulsor da investigação. É interessante salientar que, em muitos casos, para que a investigação possa trazer resultados mais consolidados do ponto de vista do argumento em construção, outras perguntas precisam ser feitas associadas ao problema central. Essas perguntas atuam como mediadoras para focar a atividade investigativa.

3) Teste de ideias: o teste pode ocorrer de maneira empírica ou hipotética. Ele está associado ao problema proposto pelo professor, mas vai além dele: é um estímulo para que os alunos coloquem em prova ideias que apresentam para a solução do problema. Muitas vezes aparece como uma condição do tipo $e$ se...

4) Delimitação de condições: trata-se da descrição e nomeação de ações realizadas na atividade e o reconhecimento dos efeitos obtidos. Sua importância sustenta-se na necessidade de que as ações sejam construídas ou reconstruídas mentalmente, o que possibilita a tomada de consciência sobre as condições em torno do fenômeno em investigação.

5) Reconhecimento de variáveis: é um passo posterior ao reconhecimento das ações realizadas. Agora o que está sendo reconhecido são as variáveis que atuam no fenômeno, considerando o grau de relevância para a sua compreensão.

6) Correlação de variáveis: uma vez que as variáveis foram explicitadas, inicia-se a construção de relações entre elas: de que modo a alteração em uma afeta a outra? Essa etapa pode favorecer a avaliação das variáveis anteriormente delimitadas, auxiliando a definir quais são as variáveis, de fato, relevantes. Aqui começam as ser construídas as explicações para o fenômeno.

7) Avaliação de ideias: construídas as relações entre as variáveis, à análise das condições limites em que certas reações ocorreriam em decorrências de certas ações permite avaliar o que foi proposto. Este movimento de encontrar os limites por meio da avaliação contribui para o estabelecimento de justificativas e de refutações para a explicação dada (SASSERON, 2013, p. 50-51).

Além dos propósitos e ações epistemológicos, Sasseron (2013) também descreve os propósitos e ações pedagógicos do professor. O papel dessas ações contribui para o procedimento e o desenvolvimento da argumentação durante a aula investigativa (Quadro 6). 


\begin{tabular}{|c|c|}
\hline \multicolumn{2}{|c|}{$\begin{array}{c}\text { PROPÓSITOS E AÇÕES PEDAGÓGICAS DO PROFESSOR PARA PROMOVER A } \\
\text { ARGUMENTAÇÃO }\end{array}$} \\
\hline $\begin{array}{l}\text { PROPÓSITOS PEDAGÓGICOS DO } \\
\text { PROFESSOR }\end{array}$ & AÇÕES PEDAGÓGICAS DO PROFESSOR \\
\hline Planejamento da atividade & $\begin{array}{l}\text { Definição dos objetivos, organização de materiais } \\
\text { necessários e preparação do cronograma. }\end{array}$ \\
\hline Organização para a atividade & $\begin{array}{l}\text { Divisão de grupos e/ou tarefas, organização do } \\
\text { espaço, distribuição de materiais, limite de tempo. }\end{array}$ \\
\hline Ações disciplinares & $\begin{array}{l}\text { Proposição clara das atividades e das ações a } \\
\text { serem realizada, atenção ao trabalho dos alunos, } \\
\text { ações disciplinares. }\end{array}$ \\
\hline Motivação & $\begin{array}{l}\text { Estímulo à participação, acolhida das ideias dos } \\
\text { alunos. }\end{array}$ \\
\hline
\end{tabular}

Quadro 6. Propósitos e ações epistemológicas do professor para aulas investigativas no ensino de Ciências. Extraído de Sasseron (2013, p. 49).

As relações entre propósitos e ações pedagógicas (SASSERON, 2013, p. 48-49) são descritas a seguir:

1) Planejamento da aula: este propósito é levantado antes da aula ocorrer. A definição dos objetivos da aula pautará todo o trabalho futuro. Os materiais precisam ser organizados e, a depender da especificidade da atividade, verificar se estão em condição de uso e se são em número suficiente para a turma. Além disso, outra ação que deve ser realizada aqui é a preparação do cronograma da aula: ainda que a aula seja dinâmica e ganhe vida a partir das interações com a turma, os objetivos definidos apontam resultados que precisam ser alcançados com uma aula ou atividade.

2) Organização para a atividade: as atividades de sala de aula podem prever ações individuais ou conjuntas. Ao iniciar a atividade o professor precisa deixar claro aos alunos como ela deve ocorrer e, em sendo o caso, agrupar os alunos para o trabalho coletivo. Para tanto, cuidados também terão de ser tomados com o gerenciamento do espaço escolar: a disposição das mesas e carteiras e dos materiais para a aula não tem papel apenas de organização dos grupos, mas também, e sobretudo, na organização do trabalho do grupo. Além disso, uma atividade deve ter tempo para iniciar e acabar: enquanto os alunos e/ou grupos estiverem verdadeiramente envolvidos com a investigação, o tempo pode ser estendido, mas é preciso estar atento para que encerrar uma etapa e iniciar outra quando o trabalho estiver satisfatório para todos.

3) Ações disciplinares: bastante relacionado ao item anterior, as ações disciplinares estão ligadas à execução das atividades, mas pautam-se em relações interpessoais. Pedir a atenção de todos para uma determinada discussão, informar qual a atividade que será feita, repreender comportamentos inadequados de alunos fazem parte das ações disciplinares da aula. No mesmo sentido, ser claro quanto ao que se pede e se espera dos alunos também é uma estratégia vinculada às ações disciplinares: muitas vezes os alunos não realizam uma atividade da maneira como se esperava apenas porque não compreenderam o que o professor solicitava. Isso pode ocorrer porque o vocabulário utilizado é desconhecido daquele público ou porque o conhecimento que possuem sobre os materiais à disposição (e o que eles podem fazer) ainda não é suficiente para a investigação.

4) Motivação: o estímulo para o trabalho com uma atividade pode ser diferente para cada aluno e o professor deve estar ciente disso. Perguntas intrigantes e possíveis de responder com a ajuda dos materiais (experimentais ou bibliográficos) são um elemento de motivação para a investigação. Estas perguntas podem ser o gatilho para a análise, mas também podem ocorrer ao longo dela, como maneira de assegurar o estudo de dados, informações e conhecimentos já existentes. Outra forma de motivação à participação dos 
alunos ocorre quando as respostas dadas por eles recebem avaliação do professor e são utilizadas na discussão com toda a turma: isso não quer dizer que apenas as respostas "corretas" devam ser esperadas; muitas vezes, um exemplo ainda não tão bem examinado trazido por um aluno pode gerar uma análise mais profunda do fenômeno em questão. No mesmo sentido, a motivação pode ocorrer quando o professor oferece oportunidades para que todos os alunos participem (SASSERON, 2013, p. 48-49).

No artigo intitulado Ações e indicadores da construção do argumento em aula de Ciências, Sasseron e Carvalho (2013) focaram na análise tanto das respostas dos alunos quanto nas ações do professor para fomentar as discussões ocorridas em sala de aula. Para analisar as ações do professor, propuseram outra ferramenta de análise: propósitos e ações do professor na promoção da construção de entendimento de ideias científicas (Quadro 7). As autoras afirmam que ações precisam ser realizadas pelo professor de modo a possibilitar que os estudantes trabalhem na construção de entendimento sobre temas debatidos em sala de aula.

\begin{tabular}{|c|c|c|}
\hline $\begin{array}{l}\text { PROPÓSITOS DO } \\
\text { PROFESSOR }\end{array}$ & AÇÕES DO PROFESSOR & $\begin{array}{c}\text { INDICADORES DE AC } \\
\text { EXPRESSOS PELOS } \\
\text { ALUNOS }\end{array}$ \\
\hline Retomada de ideias já discutidas & $\begin{array}{c}\text { Referência a ideias previamente } \\
\text { trabalhadas e/ou experiências } \\
\text { prévias dos alunos }\end{array}$ & $\begin{array}{c}\text { Organização, seriação e } \\
\text { classificação das organizações. }\end{array}$ \\
\hline Proposição de um problema & $\begin{array}{c}\text { Problematização de uma } \\
\text { situação }\end{array}$ & $\begin{array}{c}\text { Levantamento de hipóteses; teste } \\
\text { de hipóteses. }\end{array}$ \\
\hline Delimitação de variáveis & $\begin{array}{l}\text { Descrição e caracterização do } \\
\text { fenômeno e/ou de objetos }\end{array}$ & $\begin{array}{c}\text { Organização e seriação de } \\
\text { informações. }\end{array}$ \\
\hline Reconhecimento de variáveis & $\begin{array}{c}\text { Nomeação de categorias } \\
\text { advindas da caracterização }\end{array}$ & Classificação de informações. \\
\hline $\begin{array}{c}\text { Construção de relação entre } \\
\text { variáveis }\end{array}$ & Entrecruzamento de informações & $\begin{array}{l}\text { Levantamento de hipóteses; } \\
\text { explicação; previsão; } \\
\text { justificativa. }\end{array}$ \\
\hline
\end{tabular}

Quadro 7. Propósitos e ações do professor na promoção da construção de entendimento de ideias científicas (SASSERON; CARVALHO, 2013, p. 176).

O quadro anterior apresentou os propósitos e ações do professor e os indicadores de $\mathrm{AC}$ esperados para serem expressos pelos alunos. Esses indicadores estão associados à construção dos elementos constitutivos do argumento (SASSERON; CARVALHO, 2013).

No próximo item, discutiremos a ferramenta produzida por Ferraz e Sasseron (2014) e Ferraz (2015) intitulada propósitos epistêmicos e ações típicas para promoção da argumentação em aulas de Ciências. Em seguida, destacaremos as motivações que nos levam a adotar o uso dessa ferramenta. 
1.3. O PROFESSOR E A CONSTRUÇÃO DE UM ESPAÇO INTERATIVO DE ARGUMENTAÇÃO COLABORATIVA: PROPÓSITOS EPISTÊMICOS E AÇÕES TÍPICAS

Leitão (2011) relaciona argumentação e construção de conhecimento como processos indissociavelmente interligados, sendo a argumentação uma atividade privilegiada em relação ao processo de construção de conhecimento.

Sasseron e Carvalho (2013) consideram o processo de argumentação como dependente de uma rede de pequenos propósitos delimitados que emergem da interação professor-aluno-conhecimento. As autoras destacam que algumas ações precisam ser realizadas pelo professor de modo a possibilitar aos alunos trabalharem com a construção de entendimentos sobre temas debatidos em sala de aula utilizando a linguagem argumentativa.

Os propósitos do professor devem envolver um planejamento associado à estruturação dos argumentos a serem desenvolvidos nas aulas - são as intenções que o professor privilegia durante a realização das atividades. Associadas aos propósitos do professor estão suas ações, que se referem ao que de fato ele executa visando garantir suas intenções (propósitos) (SASSERON; CARVALHO, 2013).

Ferraz e Sasseron (2014) e Ferraz (2015) consideram que em situações de interação argumentativa é o professor quem assume a posição de autoridade central na dinâmica de aulas investigativas. É o professor quem propõe os problemas e conduz seus alunos a discutir e a compreender os fenômenos e conceitos que estão sendo desenvolvidos. Assim, espera-se também que o professor medeie o conhecimento juntamente com seus alunos, permitindo-os desenvolver habilidades típicas da cultura científica para resolução de problemas. Ferraz (2015) considera o efeito da mediação do professor um incentivo aos estudantes à prática da cultura científica. Afinal,

os estudantes, quando imersos em um ambiente interativo de argumentação colaborativa, fornecem hipóteses que são testadas e investigadas com o intuito de se construir entendimento sobre a situação problema que se almeja explicar. Para que o conhecimento seja construído, as hipóteses devem adquirir o status de conclusões, sendo assim, emerge a necessidade de o que o professor, mediador, tenha total conhecimento sobre o argumento que está em debate durante a investigação que está conduzindo. A clareza do conteúdo científico e, por consequência, do argumento e da explicação a serem estruturados durante o processo investigativo, é o que deve orientar o professor nas ações a serem desempenhadas e perguntas a serem proferidas em busca da evidenciação dos dados relevantes a resolução do problema pelos seus alunos, na elaboração de condições de contorno e das refutações 
que sustentarão o entendimento sobre o fenômeno investigado (FERRAZ, 2015, p. 50).

A ferramenta com objetivos de detalhar os planos e as execuções adotadas pelo professor para a construção de um espaço interativo de argumentação colaborativa são os propósitos epistêmicos e ações típicas do professor voltados para a promoção de argumentação em aulas investigativas (FERRAZ; SASSERON, 2014; FERRAZ, 2015) (ver Quadro 12 presente no Capítulo 03 - Metodologia).

A preferência em utilizar essa ferramenta deveu-se à correspondência existente entre as categorias de análise dos propósitos epistêmicos e ações típicas e as etapas da aula investigativa proposta por Carvalho (2013). Assim, na etapa de aula definida como problematização, espera-se identificar o propósito epistêmico problematizar; na etapa de resolução do problema, espera-se identificar os propósitos retomar, explorar e qualificar; na etapa de sistematização, espera-se identificar os propósitos retomar, qualificar e sintetizar; na etapa de contextualização, espera-se identificar os propósitos retomar, problematizar e explorar; e, por fim, na etapa de avaliação, espera-se identificar os propósitos retomar, qualificar e sintetizar.

Além dessa correspondência, a utilização dessa ferramenta permite evidenciar os planos e as execuções feitas pelo professor por meio da mediação com os alunos quando um dos objetivos é construir um espaço interativo de argumentação colaborativa. 


\title{
CAPÍTULO 2 - ARGUMENTAÇÃO NAS AULAS DE CIÊNCIAS
}

O presente capítulo discute o conceito e a importância da argumentação no contexto das aulas de Ciências. Apresentamos o layout de argumento de Toulmin (TAP) como uma das ferramentas de análise mais utilizadas nas investigações sobre processos de ensino e de aprendizagem em Ciências. Por fim, discutimos os limites e possibilidades de trabalho com o TAP durante argumentação oral em sala de aula.

\subsection{CONCEITO E IMPORTÂNCIA DA ARGUMENTAÇÃO NAS AULAS DE CIÊNCIAS}

No contexto do ensino de Ciências, a argumentação é definida por JimenezAleixandre e Díaz-de-Bustamante (2003) como

a capacidade de relacionar dados e conclusões, de avaliar enunciados teóricos sob luz de dados empíricos ou procedentes de outras fontes (JIMENEZALEIXANDRE, DIAZ-DE-BUSTAMANTE, 2003, p. 361, tradução nossa).

Bricker e Bell (2012, p. 119) definem a argumentação como o processo de construção de argumentos. Toulmin (2006, p. 135) considera

\begin{abstract}
$\mathrm{O}$ argumento é como um organismo: tem uma estrutura bruta, anatômica, e outra mais fina e, por assim dizer, fisiológica. Quando explicitamente exposto em todos os seus detalhes, um só argumento pode precisar de muitas páginas impressas ou talvez um quarto de hora para ser narrado; e, naquele tempo ou espaço, podem-se distinguir as fases principais que marcam o progresso do argumento a partir da afirmação principal de um problema não resolvido, até a apresentação final de uma conclusão. Cada uma dessas fases principais ocupará alguns minutos ou parágrafos, e representa as principais unidades anatômicas do argumento - seus "órgãos", por assim dizer. E podese reconhecer uma estrutura mais fina, dentro de cada parágrafo, quando se desce ao nível das sentenças individuais; com esta estrutura mais fina é que os lógicos têm-se principalmente ocupado. Neste nível fisiológico introduziuse a ideia de forma lógica e, afinal de contas, é ali que a validade de nossos argumentos tem de ser estabelecida ou refutada (TOULMIN, 2006, p. 135).
\end{abstract}

No campo dos processos de ensino e de aprendizagem de ciências, o argumento pode ter lugar como atividade individual, por meio do pensamento e da escrita, ou como uma atividade social que tem lugar dentro de um grupo - um ato social negociado dentro de uma comunidade específica (DRIVER; NEWTON; OSBORNE, 2000). 
García-de-Cajén, Domínguez-Castiñeiras e García-Rodeja Fernandez (2002, p. 220) apontam as habilidades desenvolvidas por meio da argumentação em aulas de ciências conforme o Quadro 13.

\section{HABILIDADES DESENVOLVIDAS POR MEIO DA ARGUMENTAÇ̃̃O}

1. Identificar provas e dados

2. Diferenciar atos e explicações teóricas

3. Comparar modelos teóricos e situação física real

4. Identificar razões

5. Elaborar razões

6. Formular explicações

7. Formular conclusões

8. Avaliar uma hipótese ou enunciado

9. Justificar respostas

10. Analisar criticamente

11. Realizar crítica

12. Elaborar, modificar e justificar hipóteses sobre fenômenos naturais

13. Dar argumentos e contra-argumentos

14. Avaliar consistência e coesão da argumentação

15. Usar a linguagem da ciência

16. Resolver um conflito mediante negociação social

17. Avaliar alternativas

18. Refletir acerca da evidência

19. Avaliar a viabilidade de conclusões científicas

20. Buscar coerência e globalidade

Quadro 8. Habilidades desenvolvidas por meio da argumentação nas aulas de ciências (GARCÍA DE CAJÉN; DOMÍNGUEZ-CASTIÑEIRAS; GARCÍA-RODEJA FERNANDEZ, 2002, p. 220).

As habilidades argumentativas acima destacadas também permitem elucidar a aprendizagem dos alunos. Motokane (2015, p. 128-129) considera que:

o desenvolvimento de habilidades argumentativas também promove a exteriorização da aprendizagem de um conteúdo ensinado quando os argumentos têm a chance de ser produzidos com base em elementos científicos aprendidos em aula. Ao apresentarem seus argumentos, os alunos podem expressar como utilizam um determinado conceito científico para justificar uma opinião. Dessa forma, temos um indicador claro da aprendizagem do aluno (MOTOKANE, 2015, p. 128-129).

Leitão (2011) acrescenta que ao engajar-se na argumentação, o indivíduo é levado a formular claramente seus pontos de vista e fundamentá-los mediante a apresentação de razões que sejam aceitáveis a interlocutores críticos.

Por fim, é de interesse de a educação científica formar alunos críticos e capazes de optar os diferentes argumentos que lhe são apresentados, de modo que possa tomar decisões em sua vida como cidadãos (SARDÀ JORGE; SANMARTÍ PUIG, 2000). 


\subsection{COMPONENTES DO ARGUMENTO: O LAYOUT DE TOULMIN (TAP)}

As investigações relacionadas à argumentação em aulas de ciências geralmente estão apoiadas no layout de argumento de Toulmin (TAP) (2006). Discutir este modelo exige introduzir as noções de argumento e de argumentação dentro do contexto das aulas investigativas.

A estrutura básica do argumento de Toulmin (2006) obedece ao seguinte encadeamento lógico: "a partir de um dado [D], desde que garantia [G], então conclusão $[\mathrm{C}] ”$.

Toulmin (2006) conceitua dado (D) como fatos que apoiam uma alegação e também são os fundamentos com os quais se constrói o suporte à conclusão (C). Como somente os dados não são suficientes para validar a conclusão, são necessárias informações adicionais a fim de relacionar D e C. Essas informações adicionais são garantias (G), e que permitem entender como se vincula e se constrói a relação que vai dos dados à conclusão (Figura 1).

ESTRUTURA DO LAYOUT DE ARGUMENTO DE TOLMIN (2006)

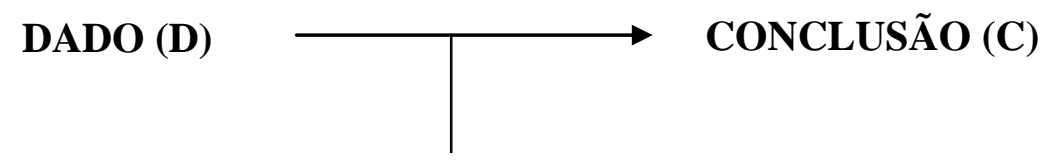

GARANTIA (G)

Figura 1. Layout de argumento de Toulmin (2006) constituído pelos elementos dado, garantia e conclusão.

Contudo, Toulmin (2006) define outros componentes do TAP: apoio (A), qualificador modal (Q) e refutador (R). O TAP incorpora explicitamente o grau de certeza (ou incerteza) do argumento mediante o qualificador modal (Q). As principais expressões que auxiliam na construção de qualificadores modais são expressões como sempre, às vezes, provavelmente, depende, necessariamente, obrigatoriamente. Em suma, o qualificador modal é uma referência explicita ao grau de força que os dados (D) conferem à conclusão (C) em virtude da garantia (G).

$\mathrm{O}$ apoio (A) são avais que conferem autoridade ou vigência às garantias (G). $\mathrm{O}$ apoio (A) se refere às circunstâncias gerais, podendo ser encontrado na forma de citações de teorias, princípios e leis científicas. O refutador (R) indica circunstâncias 
que reduz a autoridade geral da garantia (G). Por fim, conforme a Figura 2 é apresentada o layout de argumento de Toulmin (2006) contendo todos os seus componentes.

ESTRUTURA DO LAYOUT DE ARGUMENTO DE TOLMIN (2006)

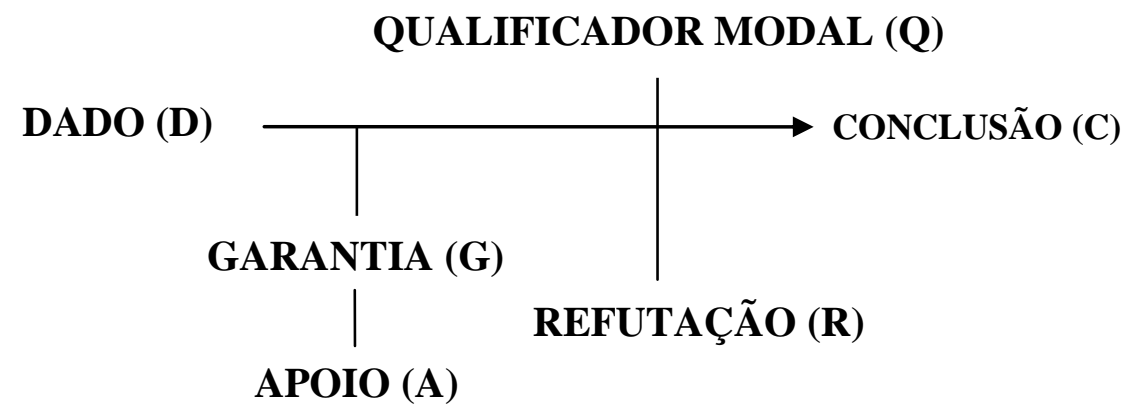

Figura 2. Layout de argumento de Toulmin (2006).

O próximo item discute os usos do TAP nas pesquisas em aulas de Ciências. Será priorizada a aplicação do TAP na argumentação oral dos alunos.

\subsection{OS USOS E AS LIMITAÇÕES DO TAP EM PESQUISAS EM ENSINO DE CIÊNCIAS ENVOLVENDO ARGUMENTAÇÃO ORAL DOS ALUNOS}

A maior parte dos estudos ligados à argumentação em situações de ensino e de aprendizagem em Ciências utilizam as ideias propostas por Toulmin (2006). Primeiramente, seu uso auxilia na classificação entre o que é o que não é um argumento (RATZ; MOTOKANE, 2014). Essa distinção entre o que é e o que não é um argumento ocorre por meio da identificação de elementos constituintes de afirmações causais coerentemente consistentes do ponto de vista das ciências (SASSERON; CARVALHO, 2013).

O TAP é utilizado tanto para análise da argumentação oral nas aulas de ciências (JIMENEZ-ALEIXANDRE, 1998; VILLANI; NASCIMENTO, 2003; ERDURAN; SIMON; OSBORNE, 2004; SASSERON; CARVALHO, 2008, 2011) quanto na análise de argumentos escritos produzidos pelos estudantes. 
O enfoque de nossa investigação é a argumentação oral nas aulas de ciências. Sasseron e Carvalho (2011) definem a argumentação oral

\footnotetext{
como todo e qualquer discurso em que aluno e professor apresentam suas opiniões em aula, descrevendo ideias, apresentando hipóteses e evidências, justificando ações ou conclusões a que tenham chegado, explicando resultados alcançados (SASSERON; CARVALHO, 2011, p. 100).
}

Quanto o uso do TAP nas investigações envolvendo argumentação oral em aulas de ciências, foi constatado algumas limitações. A primeira delas é que o TAP apenas permite identificar argumentos, mas não a qualidade deles. Outro exemplo é visto em Kelly, Druker e Chen (1998) que consideraram que há problemas de adaptação do TAP no ensino de ciências relacionados à sua aplicabilidade aos argumentos relativamente curtos e ambiguidades que surgem dos elementos lógicos do TAP quando utilizados para categorizar os enunciados que circulam no discurso argumentativo em sala de aula.

Driver, Newton e Osborne (2000) destacam que alguns elementos do TAP não são explícitos durante o processo de argumentação nas aulas de ciências. Os autores consideram também que o fluxo natural dos diálogos entre os alunos e professor não obedecem necessariamente à ordem do encadeamento lógico proposto por Toulmin. Então, as falas dos alunos e de professores podem acabar sendo classificadas com mais de um elemento do TAP. Além dessas limitações, o registro de gestos semióticos, como por exemplo, apontar objetos ou acenar com a cabeça, ou fazer uso de ilustrações e gráficos também dificultam a possibilidade de classificar cada um desses modos linguísticos como um elemento do TAP.

Outra dificuldade encontrada por muitos pesquisadores que utilizam o TAP refere-se à distinção entre os elementos garantia (G) e apoio (A). Nesse sentido, foi definida a justificativa (J) como sendo um elemento derivado da intersecção dos elementos garantia (G) e apoio (A) (ERDURAN; SIMON; OSBORNE, 2004). Todavia, é necessário destacar que os trabalhos que necessitaram o uso de justificativas para tornar o argumento passível de aceitação focam em discussões sociocientíficas.

Jiménez-Aleixandre (1998) no seu trabalho intitulado Diseño Curricular: indagación y razonamiento con el lenguaje de las ciencias propõe caracterizar o elemento dado do TAP. Quando o dado chega para os alunos por meio do professor, do livro-texto, de roteiros de experimento, classificam-no como dado fornecido (DF). Já o dado obtido (DO), a autora refere-se àquele advindo de situações experimentais. Os DO 
podem ser subclassificados em dado empírico (DE), quando os dados procedem de uma experiência em laboratório ou dado hipotético $(\mathrm{DH})$, quando os dados derivam de construções mentais para ser utilizada em uma aula investigativa.

Villani e Nascimento (2003) acrescentam uma classificação para o elemento dado: o dado resgatado (DR) que procede de impressões sobre o mundo.

Jiménez-Aleixandre (1998) apresenta outras terminologias que definem, de forma análoga, os elementos do TAP. Por exemplo, o enunciado pode ser caracterizado como uma hipótese ou como uma conclusão quando suas ideias forem válidas em uma situação. Contudo, o enunciado pode atuar como uma oposição quando questiona a validade de outro enunciado. A justificação é definida como um enunciado geral que justifica a conexão entre dado e conclusão. E o conhecimento básico que possui caráter teórico que exerce como respaldo para a justificação.

Erduran, Simon e Osborne (2004) em seu trabalho intitulado TAPping into Argumentation: Developments in the Application of Toulmin's Argument Pattern for Studying Science Discourse discutiram sobre os usos do TAP para a análise do discurso argumentativo em aulas de ciências. O objetivo desse artigo foi de se concentrar no desenvolvimento e no uso do TAP como ferramenta para rastrear a quantidade e a qualidade da argumentação no discurso científico. Como o TAP ilustra a natureza do argumento em termos de dado, garantia, apoio, refutação, qualificador modal e conclusão, o layout foi usado para investigar argumentação nas discussões entre professores e estudantes e nas discussões em pequenos grupos entre os alunos.

Os autores supracitados então sugeriram combinações duplas, triplas, quádruplas, quíntuplas e sêxtuplas de componentes, como indicativas de ordem crescente de complexidade do argumento: CDJ (conclusão - dado - justificativa); CDJB (conclusão - dado - justificativa - apoio); CDJR (conclusão - dado - justificativa refutação); CDJQ (conclusão - dado - justificativa - qualificador); CDJBQ (conclusão - dado - justificativa - apoio - qualificador); CDJBQR (conclusão - dado - justificativa - apoio - qualificador - refutação).

Sasseron e Carvalho (2011) no trabalho Construindo argumentação na sala de aula: a presença do ciclo argumentativo, os indicadores de alfabetização científica e o Padrão de Toulmin, analisaram discursos argumentativos com o TAP e com os indicadores de alfabetização científica (AC). Essa análise permitiu que as pesquisadoras concluíssem que há relações entre o TAP e os indicadores de AC: (1) o trabalho com as informações (por meio da organização, seriação ou classificação) tem o papel de 
evidenciar o conhecimento básico (ou apoio) que alicerçará as argumentações dos alunos; (2) o trabalho com as informações possibilita a percepção e a compreensão de variáveis presentes na situação problema. $\mathrm{O}$ uso de variáveis durante a construção de dados permite os alunos a utilizarem indicadores relacionados ao estabelecimento de hipóteses como forma de apresentar a ideia construída ou a se construir; (3) há uma analogia entre a conclusão sendo diretamente relacionada com o dado apresentado, assim como, uma explicação é ligada à hipótese apresentada. Os elementos que aparecem associados a uma e a outra, à conclusão e à explicação, têm como função principal, dentro do argumento, assegurar maior validade e autenticidade à proposição; (4) o uso do indicador justificativa pode ser entendida como o uso de garantias dentro do padrão de Toulmin, quando a justificativa corrobora positivamente a ideia apresentada, ou pode ser visto como a apresentação de uma condição de refutação, caso ela conteste a alegação inicial e; (5) Toulmin elenca os qualificadores modais como mais um elemento de seu padrão de argumento. Eles são termos que dão aval à conclusão obtida. Pensando nos indicadores, percebe-se que este papel cabe às previsões que se estabelecem com referência à hipótese trazida para a discussão.

Apesar das restrições do TAP, assim como das adaptações feitas a partir dessa ferramenta, destacamos que nos motivamos a utilizar o padrão como ferramenta de análise para a presente pesquisa. Primeiro porque o layout permite apresentar durante a aula a construção do raciocínio dos estudantes a uma dada situação de ensino. Como defendemos uma abordagem didática de ensino de ciências por investigação, a aula é conduzida por meio de SDI que objetivam, em linhas gerais, a alfabetização científica dos estudantes. E um dos objetivos da alfabetização científica envolve o desenvolvimento do raciocínio lógico dos estudantes. Então, por meio do TAP é favorável elucidar o entendimento, as hipóteses, as explicações e a argumentação dos alunos.

A segunda justificativa refere-se a compreender como a ação do professor atua na construção coletiva dos elementos de um argumento de Toulmin com os alunos. Afinal, a ferramenta de Ferraz e Sasseron (2014) Ferraz (2015) sugere que o professor deva promover um espaço interativo de argumentação colaborativa. Em suma, objetivamos validar a ferramenta de Ferraz e Sasseron (2014) e Ferraz (2015) para um contexto de ensino por investigação que pretende construir um espaço interativo de argumentação colaborativa, averiguada pelo TAP. 


\section{CAPÍTULO 3 - METODOLOGIA}

O presente capítulo apresenta as ferramentas metodológicas que foram utilizadas para a construção e análise de dados.

\subsection{METODOLOGIA DE PESQUISA}

O presente trabalho objetiva compreender, por meio de uma abordagem qualitativa, os aspectos que circundam os processos de ensino e de aprendizagem em aulas de Ciências.

A execução da pesquisa qualitativa na educação anseia: (a) a captação do significado subjetivo das questões a partir da perspectiva dos participantes; (b) os significados latentes de uma situação que estão em foco e; (c) a descrição das práticas sociais, do modo de vida e do ambiente em que vivem os participantes (FLICK, 2009).

Em síntese, os agentes que realizam pesquisa qualitativa, isto é, os investigadores qualitativos, se interessam mais nos significados que são construídos pelos sujeitos participantes da pesquisa.

A presente pesquisa é um estudo de caso já que incide naquilo que o caso tem de único, de particular, mesmo que posteriormente venham a evidenciar certas semelhanças com outros casos ou situações (LUDKE; ANDRE, 1986).

A pesquisa também é classificada como relacional. Como um dos objetivos específicos do presente trabalho foi a identificação e a descrição das possíveis relações entre os propósitos epistêmicos e ações típicas nas falas do professor e os elementos do TAP presentes nas falas dos alunos, consideramos relevante destacar esse ponto.

\subsection{CONTEXTO DA PESQUISA}

A produção da sequência de ensino investigativo (SDI) assim como a aplicação dos materiais produzidos ocorreu durante os meses de maio a dezembro de $2014 \mathrm{em}$ uma escola pública municipal do interior do Estado de São Paulo. O trabalho foi realizado por dois pesquisadores vinculados ao grupo de pesquisa LINCE - Linguagem e Ensino de Ciências, coordenado pelo professor Dr. Marcelo Tadeu Motokane. Esses pesquisadores atuaram na produção e aplicação da SDI e coletaram produções orais e escritas dos alunos. 
O projeto desses pesquisadores estava incluso no Programa Mais Educação, instituído pela Portaria Interministerial n ${ }^{\circ}$ 17/2007 e regulamentado pelo Decreto 7.083/10. Os objetivos principais deste programa federal são estimular a ampliação da jornada escolar e promover a organização de um currículo na perspectiva da Educação Integral.

Incluso no macrocampo de investigação no campo das ciências da natureza, o projeto previa a realização de aulas investigativas de ciências naturais e de biologia para os alunos do ensino fundamental, desde o $5^{\circ}$ ano até o $9^{\circ}$ ano. Todavia, salientamos que o interesse inicial pela realização dessas aulas investigativas não eram propriamente de pesquisa, apesar das atividades estarem rigorosamente estruturadas com o objetivo de construção de argumentos dentro do layout de argumento de Toulmin (2003) e amparadas nos pressupostos do ensino baseado na investigação (CARVALHO, 2013) com fins da alfabetização científica (SASSERON; CARVALHO, 2008, 2011) dos alunos da educação básica.

\subsection{SUJEITOS PARTICIPANTES DA PESQUISA}

Os sujeitos participantes da pesquisa foram 18 alunos do $5^{\circ}$ ano do ensino fundamental de uma escola pública municipal do interior do Estado de São Paulo e dois pesquisadores da Universidade de São Paulo, responsáveis tanto pela elaboração das atividades da SDI como também da aplicação e registro em áudio, vídeo e escrito das aulas investigativas de ciências e de biologia ocorrida com essa turma.

Sobre os pesquisadores, apresentamos as suas respectivas formações. $\mathrm{O}$ pesquisador nomeado como Dc1 é formado em Bacharelado em Biologia e mestre em Ensino de Ciências. Atualmente é doutorando em Biologia Comparada e estudante de graduação em Licenciatura em Ciências, ambas realizadas na Universidade de São Paulo. O pesquisador nomeado como Dc2 é formado em Bacharelado e Licenciatura em Biologia, mestre e doutor em Genética pela Universidade de São Paulo. O pesquisador Dc2 atua como docente da Faculdade de Filosofia, Letras e Ciências de Ribeirão Preto da Universidade de São Paulo e foi responsável tanto pela gravação das aulas como também interveio em alguns momentos para registrar pontualmente as indagações dos alunos após a visualização dos fenômenos. Ambos os pesquisadores atuaram como professores durante a aplicação da SDI, sendo identificados com a sigla 'P' nas transcrições. 


\subsection{SEQUÊNCIA DIDÁTICA INVESTIGATIVA (SDI) SOBRE SERES VIVOS}

Para a presente investigação, os pesquisadores criaram uma SDI contendo o total de 27 atividades. Cada uma dessas atividades segue as orientações propostas por Motokane (2015) que apoia tanto a abordagem didática de ensino por investigação (CARVALHO, 2013) e da alfabetização científica (SASSERON; CARVALHO, 2011) e a promoção de argumentação na sala de aula.

Devido à grande extensão da SDI, selecionamos um conjunto de quatro atividades que trabalharam com o conteúdo conceitual "características dos seres vivos". As atividades tinham como conteúdos procedimentais observar objetos e fenômenos naturais; reconhecer problemas; formular hipóteses; identificar e controlar variáveis durante montagem de experimento; planejar experimentos; escolher materiais e métodos adequados para resolução do problema proposto; trabalhar em equipe para discutirem sobre os resultados obtidos e das informações e conceitos relacionados à atividade; identificar e diferenciar dado, garantia e conclusão; elaboração de previsões, explicações e justificativas; seriar, organizar e classificar informações. Dentre os conteúdos atitudinais esperados para ser desenvolvidos, esperava-se que o aluno: valorize suas próprias ideias; respeite as opiniões dos outros; respeite as regras de organização da turma na hora da discussão; aceite as decisões do grupo; colabore com os colegas em trabalhos de grupo; desenvolva iniciativa na busca de soluções de problemas.

As atividades foram planejadas com base em dois dos três eixos estruturantes da alfabetização científica: (1) Compreensão básica de termos, conhecimentos e conceitos científicos fundamentais - $\mathrm{O}$ principal conceito abordado é o de ser vivo. Além de ser um conceito fundamental em Biologia, é também um dos mais complexos. Ao enfocar as características dos seres vivos, as atividades também trabalham com outros conceitos básicos da biologia, como célula e; (2) Compreensão da natureza da ciência e dos fatores éticos e políticos que circundam sua prática - As atividades permitem os alunos a resolver um problema por meio do pensamento científico. Ao realizar procedimentos e a desenvolver raciocínios, habilidades e competências semelhantes aos adotados pelos cientistas, os alunos podem ser estimulados a refletir sobre a forma como as investigações científicas são realizadas.

Todavia, para construção de nossos dados utilizamos apenas trechos da aula 01 para análise. A atividade que orientou a condução da aula está disponível no Anexo 01. 
A escolha dessa aula para nossa análise deve-se às seguintes justificativas. Primeiramente, porque uma das práticas sugeridas pelos parâmetros curriculares nacionais (PCN) é promover o estudo especial dos seres vivos habitantes de diferentes ambientes, buscando descrever e compreender diferentes formas de vida (BRASIL, 1998). A observação, a descrição e o registro de um objeto de estudo (no caso da aula 01, a levedura) são fundamentais para comparar a natureza biológica dos diferentes seres vivos, a fim de reconhecer diferentes padrões de estrutura e funcionamento. E por meio da intervenção do professor, a observação, a descrição e o registro dos alunos ganham rigor e precisão. E a aula 01 prevê a execução dessas práticas.

Outra justificativa que ampara a seleção dessa aula é devido à possibilidade de o professor estimular os alunos a produzir um argumento potencial oral. A aula 01 teve como objetivo estimular os alunos a produzir o argumento potencial baseado na observação e identificação das leveduras por meio do microscópio e que os alunos reconheçam que as leveduras são células e, portanto, seres vivos. Em suma, a intenção do professor é que os alunos compreendam que a presença de células é apenas uma evidência que caracteriza a presença de seres vivos na amostra.

A sala de aula foi organizada da seguinte forma: um total de dezoito alunos foram distribuídos em três mesas, sendo seis para cada mesa. A atividade ocorreu nesses pequenos grupos, sendo que os alunos interagiam entre si, com a mediação do professor.

A seguir, o quadro 9 apresenta a descrição resumida das atividades que trabalharam com evidências sobre seres vivos.

\begin{tabular}{|c|c|c|}
\hline AULA & $\begin{array}{l}\text { ATIVIDADE } \\
\text { PROPOSTA }\end{array}$ & DESCRIÇÃO DE ATIVIDADES \\
\hline 01 & $\begin{array}{l}\text { Testando a presença de seres } \\
\text { vivos. }\end{array}$ & $\begin{array}{l}\text { Leitura de texto introdutório; } \\
\text { Trabalho em grupo: Resolução do problema: “Como identificar a } \\
\text { presença de micro-organismos em amostras desconhecidas?"; } \\
\text { Utilização de microscópio para observação das amostras. }\end{array}$ \\
\hline 02 & $\begin{array}{l}\text { Testando a presença de seres } \\
\text { vivos. }\end{array}$ & $\begin{array}{l}\text { Elaboração de conclusões sobre a observação microscópica; } \\
\text { Leitura de texto introdutório: retomada do problema e introdução } \\
\text { de novas variáveis; } \\
\text { Leitura de tabela sobre características do metabolismo de micro- } \\
\text { organismos; } \\
\text { Proposição de testes experimentais utilizando informações da } \\
\text { tabela. }\end{array}$ \\
\hline 03 & $\begin{array}{l}\text { Testando a presença de seres } \\
\text { vivos. }\end{array}$ & $\begin{array}{l}\begin{array}{l}\text { Realização de experimento controlado com as amostras } \\
\text { desconhecidas. }\end{array} \\
\end{array}$ \\
\hline 04 & $\begin{array}{l}\text { Testando a presença de seres } \\
\text { vivos. }\end{array}$ & $\begin{array}{l}\text { Elaboração de painéis estabelecendo relações entre dados e } \\
\text { explicações produzidos nas aulas anteriores para a construção de } \\
\text { uma conclusão final. }\end{array}$ \\
\hline
\end{tabular}

Quadro 9. Síntese das aulas da SDI utilizada como recurso para origem dos dados. 


\subsection{CONSTRUÇÃO DE DADOS}

Os dados para a presente investigação foram obtidos por meio da aplicação de uma SDI. A aplicação foi registrada por uma câmera de áudio e vídeo. Após assistir a aula 01, identificamos os momentos em que ocorreu a mediação do professor para estimular os alunos a construir argumentos orais e, posteriormente, transcrevemos as falas de professores e dos alunos.

A transcrição ocorreu somente no momento de resolução da atividade ocorreu devido à grande extensão do período de gravação bem como à intenção de agregar esta decisão ao tipo de problema que está sendo estudado e ao propósito do estudo. Afinal, para apresentação dos resultados, o que nos interessou para o estudo é identificar os processos argumentativos mediados pelas ações do professor.

A transcrição do áudio obedeceu à sequência cronológica dos eventos.

A aula tinha como problema: "Como identificar a presença de micro-organismos em amostras desconhecidas?". Para a realização da aula, fez-se a leitura de um texto introdutório e utilizou-se microscópio para observação de algumas amostras contendo leveduras. Em seguida, o professor fez as seguintes perguntas:

a) O que foi observado na amostra?

b) Baseado nessa observação, essa amostra contém seres vivos ou não?

c) Por que você (o aluno) acha que a amostra contém (ou não contém) seres vivos?

A apresentação dos diálogos dos alunos e do professor da atividade analisada foi baseada na ferramenta proposta por Preti (1999) (Quadro 10).

\begin{tabular}{|c|c|}
\hline SIMBOLOS & OCORRÊNCIAS \\
\hline() & Incompreensão de palavras ou segmentos \\
\hline (hipótese) & Hipótese do que se ouviu \\
\hline I & Truncamento \\
\hline $\begin{array}{c}:: \\
\text { para }:::: \text { ou mais }\end{array}$ & Prolongamento de vogal ou consoante \\
\hline$-{ }_{-}^{-}-$ & Silabação \\
\hline$?$ & Interrogação \\
\hline$\ldots$ & Qualquer pausa \\
\hline$(())$ & Intervalos descritivos do transcritor \\
\hline-- & Comentários que quebram a sequência temática da exposição \\
\hline\{ & $\begin{array}{l}\text { Superposição, simultaneidade de falas (a fala que se sobrepõe corresponde ao turno } \\
\text { seguinte) }\end{array}$ \\
\hline$(\ldots)$ & Indicação de que a fala foi interrompida em determinado momento \\
\hline " " & Citações literais de leituras do texto \\
\hline
\end{tabular}


Para apresentar as falas dos sujeitos e classificá-las, compomos um quadro (Quadro 11) contendo as seguintes informações: turno, sujeito, fala, propósito epistêmico e ação típica (para o professor) e os elementos do TAP (para o aluno). Para identificar os sujeitos, adotamos as siglas ' $\mathrm{P}$ ' indicando falas proferidas pelo professor e 'A1' até 'A18' indicando falas proferidas pelos alunos. Adotamos a sigla 'An' em situações onde ocorre a exteriorização de falas proferidas por mais de um aluno.

\begin{tabular}{|c|c|c|c|c|c|}
\hline \multirow[t]{2}{*}{ TURNO } & \multirow[t]{2}{*}{ SUJEITO } & \multirow[t]{2}{*}{ FALA } & \multicolumn{2}{|c|}{ PROFESSOR } & ALUNO \\
\hline & & & $\begin{array}{l}\text { PROPÓSITO } \\
\text { EPISTÊMICO }\end{array}$ & $\begin{array}{r}\text { AÇÃ̃O } \\
\text { TÍPICA }\end{array}$ & $\begin{array}{c}\text { ELEMENTOS } \\
\text { DO TAP }\end{array}$ \\
\hline $\begin{array}{l}\text { [Indicado por } \\
\text { número que } \\
\text { apresenta a } \\
\text { ordem } \\
\text { cronológica } \\
\text { das falas]. }\end{array}$ & $\begin{array}{l}\text { [Refere-se ao } \\
\text { autor da fala]. }\end{array}$ & $\begin{array}{l}\text { [Apresenta } \\
\text { aquilo que foi } \\
\text { falado pelos } \\
\text { professores e } \\
\text { alunos. Será } \\
\text { organizada a } \\
\text { partir da } \\
\text { sugestão feita } \\
\text { por } \\
(1999)] .\end{array}$ & $\begin{array}{c}\text { [Classificação } \\
\text { utilizada para } \\
\text { verificar que } \\
\text { tipo de } \\
\text { propósito } \\
\text { epistêmico o } \\
\text { professor } \\
\text { utilizou]. }\end{array}$ & $\begin{array}{c}\text { [Ação por } \\
\text { meio da qual o } \\
\text { professor tenta } \\
\text { alcançar o } \\
\text { propósito } \\
\text { epistêmico]. }\end{array}$ & $\begin{array}{l}\text { [Dispõe sobre } \\
\text { os elementos do } \\
\text { argumento de } \\
\text { Toulmin na fala } \\
\text { do aluno]. }\end{array}$ \\
\hline
\end{tabular}

Quadro 11. Organização do quadro contendo as falas dos sujeitos durante a aula e a classificação da fala do professor e dos alunos.

A classificação das falas do professor foi feita pela ferramenta proposta por Ferraz e Sasseron (2014) e Ferraz (2015) intitulada propósitos epistêmicos e ações típicas para argumentação em aulas investigativas de ciências. As falas dos alunos foram analisadas por meio do layout de argumento de Toulmin (2006). Após a classificação das falas, foi possível converter aquilo que é qualitativo em numérico, permitindo, por fim, a tabulação dos dados por meio de tabelas e gráficos, facilitando assim a compreensão do pesquisador para uma consequente análise e interpretação.

\subsection{PROPÓSITOS EPISTÊMICOS E AÇÕES TÍPICAS DO PROFESSOR PARA PROMOÇÃO DA ARGUMENTAÇÃO}

No Capítulo 1, item 1.3, foi definido os propósitos e ações típicas do professor. A seguir apresentamos o quadro 12 que sumariza cada uma das ações típicas associadas a cada propósito epistêmico específico.

Assim, um dos objetivos específicos do presente trabalho foi de caracterizar os propósitos epistêmicos e as ações típicas dos professores participantes da aula. 


\begin{tabular}{|c|c|c|}
\hline $\begin{array}{l}\text { PROPÓSITO } \\
\text { EPISTÊMICO }\end{array}$ & AÇÃO TÍPICA & DEFINIÇÃO \\
\hline \multirow[t]{3}{*}{ Retomar } & Retoma conceitos & $\begin{array}{l}\text { É a ação por meio da qual o professor faz um recrutamento } \\
\text { de conceitos estudados em outros momentos. }\end{array}$ \\
\hline & Retoma dados & $\begin{array}{l}\text { Trata-se de um levantamento de dados já trabalhadas em } \\
\text { outros momentos, sejam em uma mesma aula, em outras } \\
\text { aulas, ou então em outros anos escolares. }\end{array}$ \\
\hline & $\begin{array}{c}\text { Retoma } \\
\text { informações }\end{array}$ & $\begin{array}{l}\text { É a ação que traz para a discussão com os alunos } \\
\text { informações já conhecidas e necessárias para compreensão e } \\
\text { construção de explicações sobre a situação, o fenômeno ou } \\
\text { objeto que está sendo investigado. }\end{array}$ \\
\hline \multirow[t]{2}{*}{ Problematizar } & $\begin{array}{l}\text { Problematiza uma } \\
\text { situação }\end{array}$ & $\begin{array}{l}\text { Ação na qual o professor orienta uma nova discussão a partir } \\
\text { de um novo problema. Esse problema pode ser originado por } \\
\text { meio de explicações e conclusões anteriores dos alunos e que } \\
\text { exigem maior aprofundamento. }\end{array}$ \\
\hline & $\begin{array}{l}\text { Propõe um } \\
\text { problema }\end{array}$ & $\begin{array}{l}\text { Ação na qual o professor, por meio da proposição de um } \\
\text { problema, tem como objetivo tornar o objeto de estudo } \\
\text { passível de investigação pelos alunos. }\end{array}$ \\
\hline \multirow[t]{2}{*}{ Explorar } & $\begin{array}{l}\text { Explora condições } \\
\text { de investigação }\end{array}$ & $\begin{array}{l}\text { Por meio dessa ação o professor almeja um melhor } \\
\text { entendimento dos alunos sobre o trabalho com variáveis, } \\
\text { materiais e métodos durante a investigação. }\end{array}$ \\
\hline & $\begin{array}{l}\text { Explora ponto de } \\
\text { vista }\end{array}$ & $\begin{array}{l}\text { É o viés relacionado às asserções proferidas pelos alunos ao } \\
\text { longo da investigação sobre a situação que está sendo } \\
\text { investigada ou sobre o próprio objeto de estudo. Essa ação } \\
\text { tem como objetivo levar o aluno a desenvolver suas } \\
\text { asserções, explicitando hipóteses, raciocínios e conclusões } \\
\text { além de garantir que os demais alunos que estão participando } \\
\text { da discussão também compreendam o que está sendo } \\
\text { exposto. }\end{array}$ \\
\hline \multirow[t]{3}{*}{ Qualificar } & $\begin{array}{l}\text { Qualifica contexto } \\
\text { de investigação }\end{array}$ & $\begin{array}{l}\text { Ação que objetiva delimitar o contexto de investigação a } \\
\text { partir da diminuição do número de elementos que devem ser } \\
\text { levados em conta durante o processo de construção de } \\
\text { explicações e entendimentos pelos alunos. }\end{array}$ \\
\hline & $\begin{array}{c}\text { Qualifica } \\
\text { explicações ou } \\
\text { pontos de vista }\end{array}$ & $\begin{array}{l}\text { Ação do professor de caracterizar hipóteses e explicações } \\
\text { apresentadas pelos alunos, de forma que sejam incorporadas } \\
\text { ao processo investigativo ou descartadas por serem } \\
\text { incoerentes ou estarem fora do contexto da investigação. } \\
\text { Essa ação pode vir acompanhada de breves avaliações. }\end{array}$ \\
\hline & $\begin{array}{l}\text { Qualifica } \\
\text { variáveis, objetos } \\
\text { ou fenômenos }\end{array}$ & $\begin{array}{l}\text { Ação do professor de caracterizar informações trazidas à } \\
\text { discussão, tais como dados, variáveis, objetos ou fenômenos, } \\
\text { de forma que sejam incorporadas ao processo investigativo } \\
\text { ou descartadas por serem incoerentes ou estarem fora do } \\
\text { contexto da investigação. Essa ação pode vir acompanhada } \\
\text { de breves avaliações. }\end{array}$ \\
\hline \multirow[t]{2}{*}{ Sintetizar } & $\begin{array}{c}\text { Sintetiza } \\
\text { explicações }\end{array}$ & $\begin{array}{l}\text { Ação do professor que tem como objetivo organizar } \\
\text { explicações proferidas de forma fragmentada pelos alunos. }\end{array}$ \\
\hline & $\begin{array}{c}\text { Sintetiza } \\
\text { informações }\end{array}$ & $\begin{array}{l}\text { Ação do professor que tem como objetivo organizar } \\
\text { informações proferidas de forma fragmentada pelos alunos. }\end{array}$ \\
\hline
\end{tabular}

Quadro 12. Propósitos epistêmicos e ações típicas do professor para promoção da argumentação dos alunos em aulas investigativas (FERRAZ; SASSERON, 2014; FERRAZ, 2015).

\subsection{LAYOUT DE ARGUMENTO DE TOULMIN}

O padrão de argumento do Toulmin (TAP) (2006) foi à ferramenta utilizada para identificação dos elementos presentes nas falas dos alunos. Assim, as falas foram 
classificadas em dado (D), garantia (G), apoio (A), qualificador modal (Q), refutação (R) e conclusão (C).

A apresentação do argumento construído coletivamente durante a aula também será apresentada por meio do TAP (ver Figuras 1 e 2 no Capítulo 02).

O layout de Toulmin é uma ferramenta útil para a compreensão do papel da argumentação no pensamento científico. O layout permite visualizar como os alunos relacionam dados e conclusões por meio de garantias de caráter teórico/hipotético, e, por exemplo, se ele compreende o papel dos dados na defesa de um posicionamento e se reconhece as limitações de uma dada garantia em detrimento de outra.

O quadro 13 apresenta as definições de cada um dos elementos do TAP.

\begin{tabular}{|c|c|}
\hline $\begin{array}{c}\text { ELEMENTO DO } \\
\text { LAYOUT DE } \\
\text { TOULMIN }\end{array}$ & DESCRIÇÃO \\
\hline Dado $(\mathrm{D})$ & Fatos apresentados para a defesa de uma alegação. \\
\hline Conclusão (C) & Alegação que buscamos defender. \\
\hline Garantia $(G)$ & $\begin{array}{l}\text { Afirmações (gerais ou hipotéticas) que autorizam a passagem do dado para a } \\
\text { conclusão. }\end{array}$ \\
\hline Apoio (A) & $\begin{array}{l}\text { São avais campo-dependente que conferem autoridade ou vigência às } \\
\text { garantias. }\end{array}$ \\
\hline $\begin{array}{l}\text { Qualificador Modal } \\
\text { (Q) }\end{array}$ & $\begin{array}{l}\text { "[...] referência explícita ao grau de força que nossos dados conferem à nossa } \\
\text { alegação em virtude de nossa garantia." (TOULMIN, 2006, p. 145). }\end{array}$ \\
\hline Refutador $(\mathbf{R})$ & $\begin{array}{c}\text { "[...] indicam circunstâncias nas quais se tem de deixar de lado a autoridade } \\
\text { geral da garantia" (TOULMIN, 2006, p. 145). }\end{array}$ \\
\hline
\end{tabular}

\subsection{TABULAÇÃO: CONSTRUÇÃO E INTERPRETAÇÃO DE TABELAS E GRÁFICOS}

A tabulação dos dados é o processo de agrupar e contar os casos que estão nas várias categorias de análise. A tabulação pode ser simples e cruzada, assim como manual e eletrônica (BARTH-TEIXEIRA, 2003, p. 196).

O método tabular permite a construção de gráficos que representam a distribuição de frequência, que atua como um sumário tabular de dados e mostra o número (frequência) de itens em cada uma das diversas classes não sobrepostas. Em nossa investigação, adotamos esse procedimento com finalidade de apresentar os dados numéricos encontrados na aula 01. Neste sentido, foram construídas tabelas que apresentam a frequência em porcentagem de propósitos epistêmicos e de ações típicas do professor relacionadas com cada um dos elementos do TAP encontrados. 
Em nossa pesquisa, de cunho relacional, pretendeu-se evidenciar como os propósitos epistêmicos e ações típicas atuam na promoção da argumentação oral dos alunos durante as aulas investigativas. Por meio da representação gráfica dos dados relativos ao objetivo de nosso trabalho, é esperada a construção de relações entre os dados obtidos e os fenômenos estudados, enquanto que a interpretação é uma atividade que leva o pesquisador a dar um significado mais amplo às respostas (BARTHTEIXEIRA, 2003).

Adicionamos ainda que a análise e a interpretação são dois processos da pesquisa que estão estreitamente relacionados, o que dificulta precisar onde termina a etapa da análise e começa a da interpretação. A interpretação dos dados na pesquisa social refere-se à relação entre os dados empíricos e a teoria. É recomendável que haja um equilíbrio entre o arcabouço teórico e os dados empiricamente obtidos, a fim de que os resultados da pesquisa sejam reais e significativos (BARTH-TEIXEIRA, 2003, p. 197). 


\section{CAPÍTULO 4 - RESULTADOS E DISCUSSÃO}

No presente capítulo apresentamos os resultados e as análises provenientes dos dados. Primeiramente, apresentamos as classificações feitas nas falas dos professores e dos alunos. Em seguida, apresentamos os argumentos orais presentes na aula e identificamos as relações entre os propósitos epistêmicos e as ações típicas do professor e os elementos do TAP.

\subsection{PROPÓSITOS EPISTÊMICOS E AÇÕES TÍPICAS PRESENTES NA AULA}

A aula analisada teve como objetivo fazer os alunos discutirem se uma amostra desconhecida continha ou não seres vivos, elencando as razões que garantiriam as devidas conclusões.

A transcrição e as classificações feitas na aula estão disponíveis no Apêndice $\mathrm{C}$ do trabalho.

A aula é iniciada com o professor P perguntando ao aluno A16 sobre a amostra observada no microscópio óptico. Os propósitos retomar no turno 01 e explorar no turno 11 contribuíram para ajudar o aluno a elencar os dados do argumento 01. Esses dados (turnos 02, 12 e 14) referiram-se ao tamanho e à ausência de motilidade das estruturas observadas no microscópio.

O professor utilizou o propósito problematizar para que o aluno verbalizasse sua conclusão destacando se a amostra continha ou não seres vivos (turnos 05 e 06). Em seguida, por meio do propósito explorar (turno 07) o professor P tenta estimular o aluno a externalizar as razões que o levaram a concluir que não havia seres vivos na amostra. O aluno A16 retoma o dado sobre a ausência de motilidade (turno 08) para justificar sua conclusão de que a amostra não contém seres vivos. Esse dado portanto expressa uma garantia implícita no pensamento do aluno - a premissa de que só podemos considerar vivos seres dotados de movimento ("seres que se mexem").

Justamente para fazer o aluno reavaliar essa garantia/premissa implícita, o professor $\mathrm{P}$ utiliza uma série de ações relacionadas aos propósitos explorar e qualificar. Por meio desses propósitos, o aluno A16 pôde começar a pensar em refutações do seu argumento.

No turno 32 a ação do professor, por meio do propósito explorar, é estimular o aluno a denominar o que poderiam ser as estruturas (as "bolinhas") observadas ao 
microscópio. O aluno A14 denomina as bolinhas como bactérias, o que pode ser entendido como uma garantia do argumento. Seria como se o aluno A14 dissesse que “dado que eu vejo essas estruturas, eu concluo que há seres vivos, já que essas estruturas parecem bactérias e todos sabemos que bactérias são seres vivos".

No turno 62 o professor novamente fez uso do propósito explorar com o objetivo de verificar se os alunos conseguiam associar as características das estruturas observadas ao microscópio com outros conhecimento biológicos. Nesse momento, o aluno A14 consegue trazer para a discussão o conceito de célula, embora não saiba explicá-lo/desenvolvê-lo (é como se o aluno A14 reforçasse sua garantia dizendo: “essas estruturas também parecem células e células são estruturas vivas - turnos 61, 77, então por isso é possível concluir que se trata de uma amostra de seres vivos”).

A partir do turno 64, o professor realiza uma série de falas com o propósito retomar, para tentar verificar se o aluno já possui uma definição para o conceito de célula. Essa definição acaba não sendo desenvolvida nem pelos alunos e nem pelo professor. Apesar dessas garantias, mais associadas à morfologia das estruturas visualizadas (e à premissa de que essa é uma morfologia típica de estruturas vivas como células e bactérias), é interessante observar que a premissa associada à "obrigatoriedade do movimento" continua sendo utilizada pelo aluno (turno 82), o que exige do professor repetir ações ligadas com o propósito qualificar voltado à construção de refutações.

A partir do turno 93, os sujeitos continuam investindo um bom tempo discutindo a "força" da garantia referente à motilidade das estruturas microscópicas observadas. Isso continua exigindo do professor ações insistentes relacionadas ao propósito qualificar, de modo a redirecionar os alunos para as garantias que ele considera mais válidas para construir o argumento durante essa aula - garantias relacionadas ao conceito de "célula".

No turno 138 o professor então tenta encerrar a discussão sobre "motilidade" e do turno 144 em diante, toda a mediação almeja desenvolver com os alunos a compreensão do por que as estruturas visualizadas podem ser consideradas células e consequentemente, eles podem concluir que há seres vivos na amostra. Trata-se então de um grande esforço do professor para conseguir o que não foi realizado anteriormente - que é o desenvolvimento das garantias do argumento. O professor almeja que os alunos tenham condições de defender que a presença de células é uma evidência da presença de "vida" mais robusta do que a presença de motilidade. O propósito mais utilizado pelo professor durante a sistematização da aula foi o qualificar, 
comprometido justamente com fazer essa série de ponderações que levassem o aluno a melhorar a qualidade das garantias que vão sendo construídas em turnos como o 157 , 159, 161, 162, 166, 178, 180, 183, 191 e 193.

Em síntese, as frequências de propósitos epistêmicos apresentados pelo docente foram: $37,8 \%$ qualificar, $27,6 \%$ explorar, $22,8 \%$ retomar, $8,7 \%$ sintetizar e $3,1 \%$ problematizar. Associados a esses propósitos o professor fez uso das ações típicas na proporção apresentada na figura 3 para mediar à construção dos argumentos durante a aula.

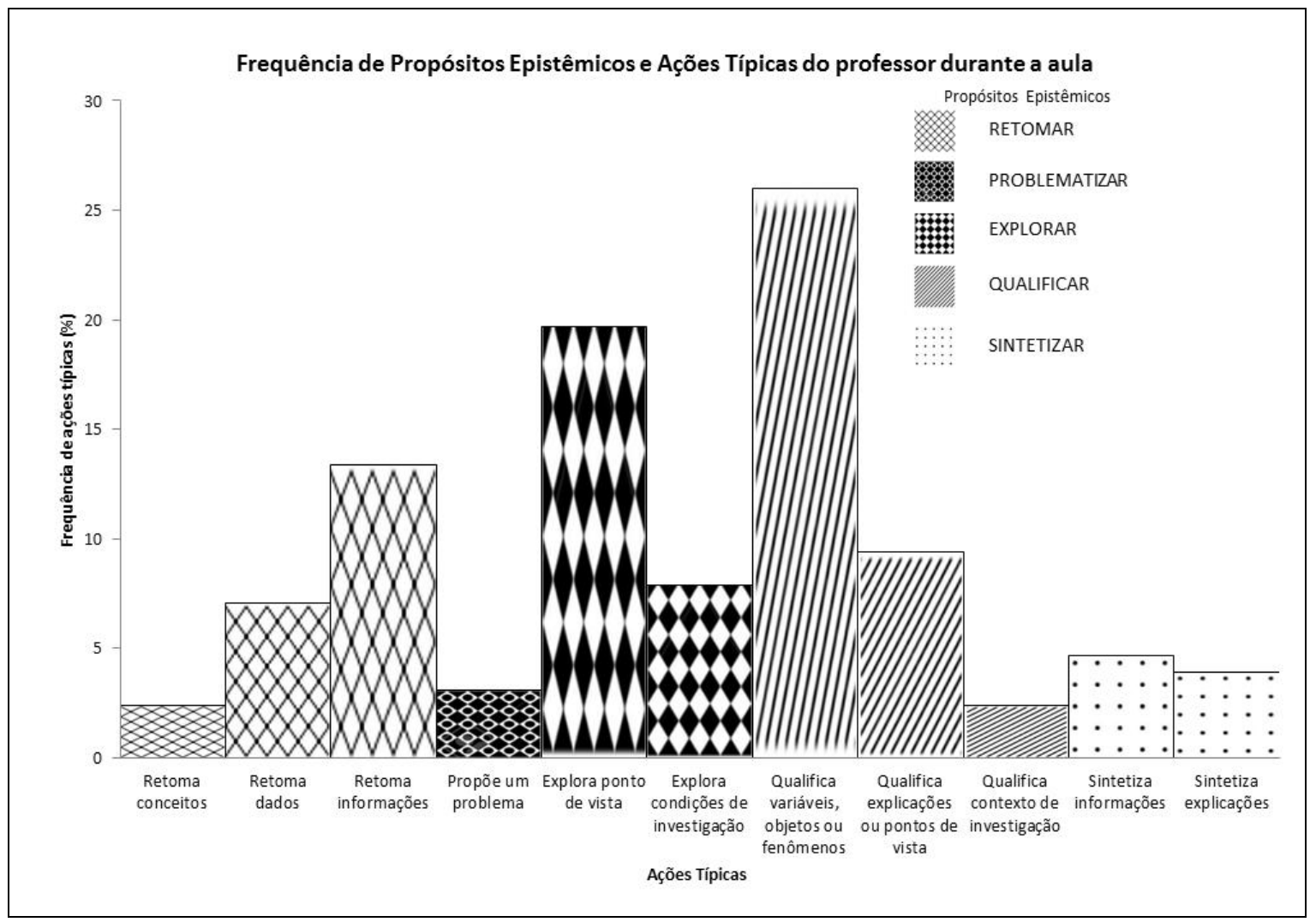

Figura 3. Frequência de propósitos epistêmicos e as ações típicas registrados durante a aula.

Observou-se que as ações típicas mais frequentes foram o explora ponto de vista $(19,7 \%)$ e o qualifica variáveis, objetos ou fenômenos (26\%). Outras porcentagens podem ser consultadas na tabela 5 presente no item Apêndice B.

\subsection{ARGUMENTAÇÃO OCORRIDA NA AULA}

A frequência de elementos do TAP classificados nas falas dos alunos durante a aula é apresentada na figura 4. 


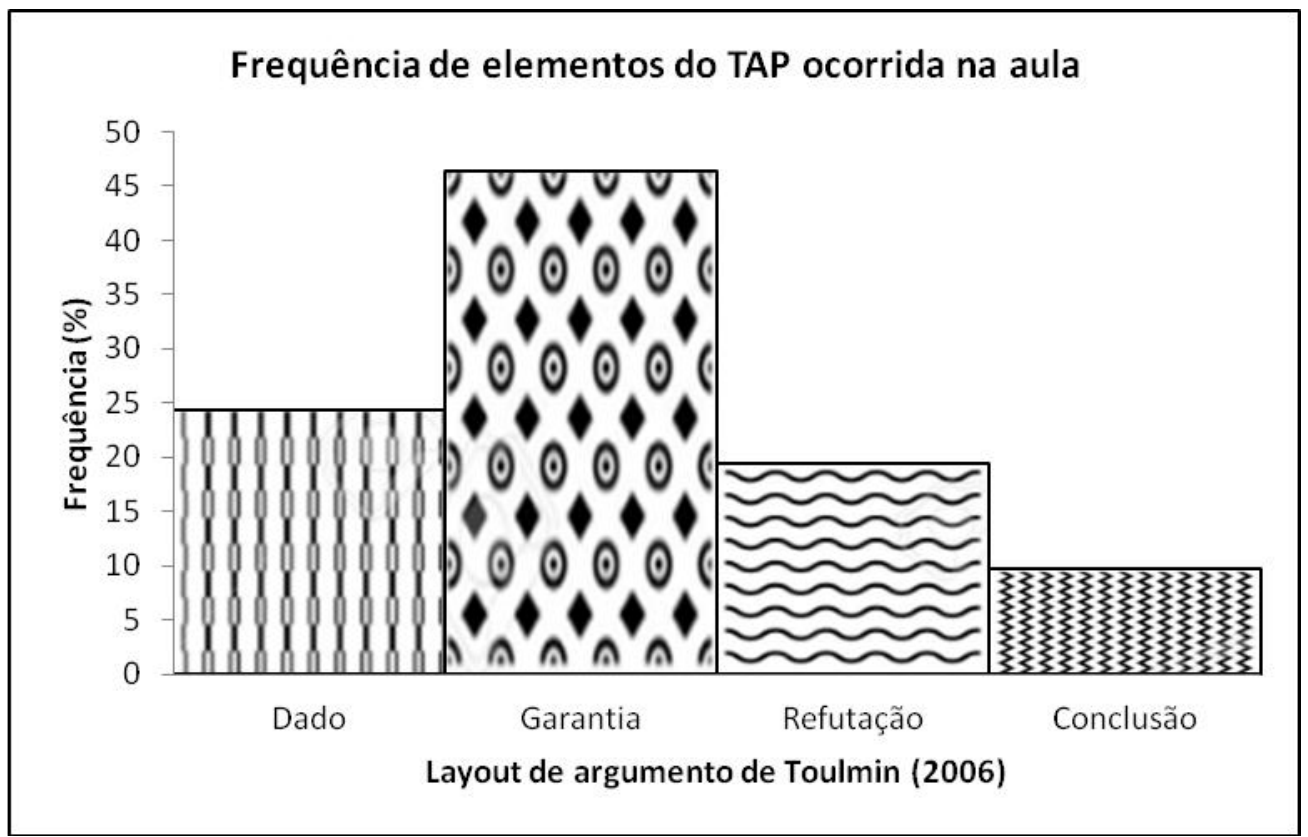

Figura 4. Frequência de elementos do TAP registrados durante a aula.

A maior ocorrência de garantias $(46,3 \%)$ demonstra o efeito produzido pela mediação do professor. A frequência absoluta e em porcentagem pode ser consultada no Apêndice B (Tabela 6). No item 4.3 discutiremos a relação entre os propósitos epistêmicos e ações típicas e os elementos do TAP.

A identificação dos argumentos deveu-se à classificação das falas com o TAP e por meio da interpretação de todo o contexto da aula. Foram encontrados dois argumentos: o argumento 01 que contém a combinação CDJR (conclusão - dado justificativa - refutação) e, o argumento 02 que possui a estrutura CDJ (conclusão dado - justificativa) (ERDURAN; SIMON; OSBORNE, 2004).

Os dois argumentos são apresentados nas figuras 5 e 6.

Os argumentos apresentaram a mesma conclusão: há seres vivos na amostra. Contudo, o argumento 01, que utiliza como dado a presença de movimento das estruturas circulares visualizadas no microscópio e considera como garantia que a motilidade é indício de vida. Esse argumento vai sendo questionado pelo professor que tenta "desequilibrar" os alunos conduzindo o raciocínio para construção de uma refutação com a finalidade de diminuir a força desse primeiro argumento. 


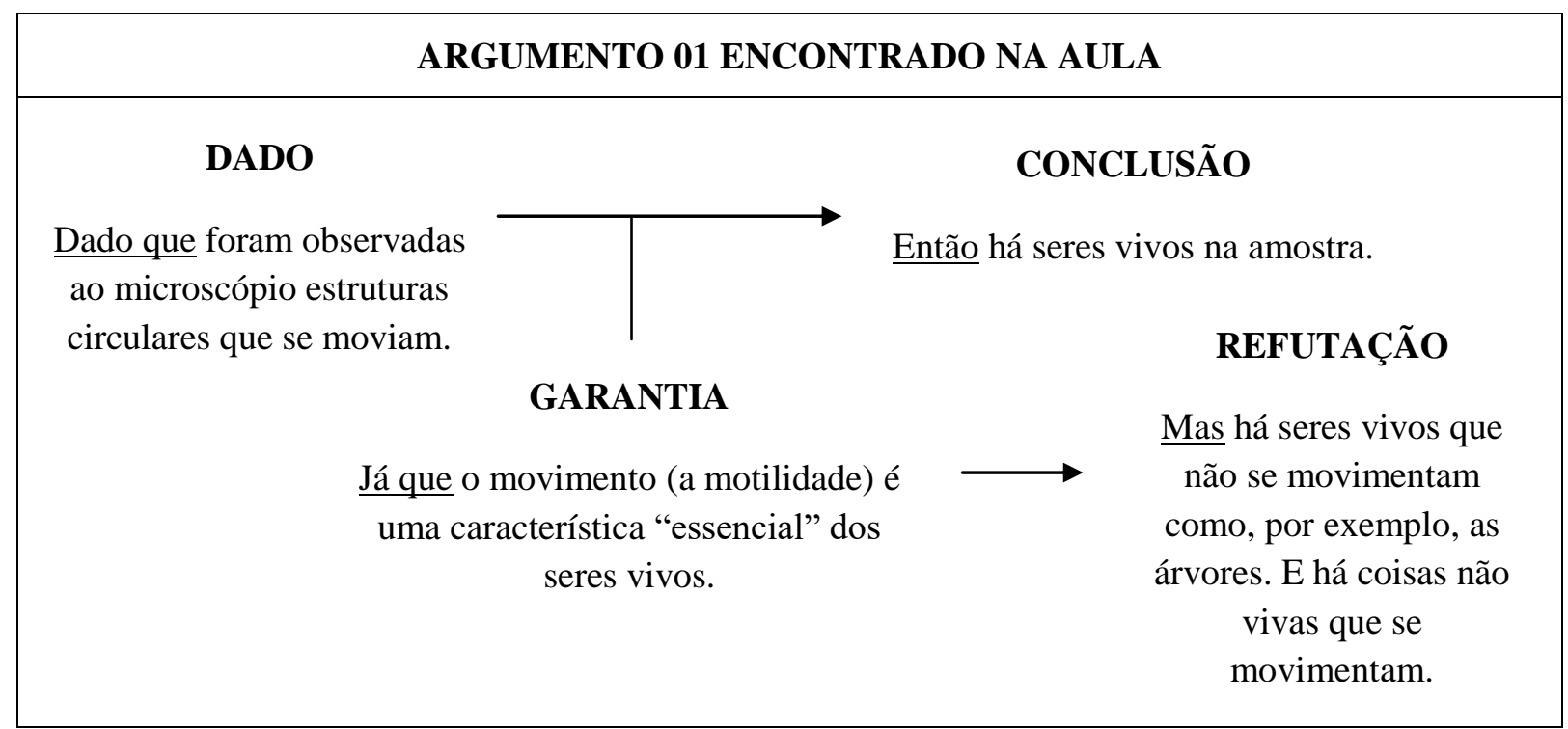

Figura 5. Estrutura do argumento oral desenvolvidos na aula analisada. A estrutura do argumento é apresentada por meio do layout de argumento de Toulmin (2006), com auxílio de elementos de coesão: "dado que", "já que", "então" e "mas".

O segundo argumento, que considera apenas a morfologia do objeto observado e, privilegia como garantias, apenas premissas relacionadas à teoria celular, aparece de forma fragmentada na fala dos alunos e do professor a partir do turno 93, principalmente na fala do professor quando ele está sistematizando a aula (quando está utilizando simultaneamente vários propósitos, como o retomar, qualificar e sintetizar).

\section{ARGUMENTO 02 ENCONTRADO NA AULA}

\section{DADO}

Dado que foram observadas ao microscópio estruturas circulares.

\begin{abstract}
GARANTIA
Já que as estruturas circulares parecem ser células. As células são as menores unidades morfofisiológicas que caracterizam os seres vivos.
\end{abstract}

Figura 6. Estrutura do argumento oral desenvolvidos na aula analisada. A estrutura do argumento é apresentada por meio do layout de argumento de Toulmin (2006), com auxílio de elementos de coesão: "dado que", "já que" e "então".

No próximo item, discutiremos as relações encontradas entre os propósitos epistêmicos e ações típicas com os elementos do TAP. 


\subsection{RELAÇÕES ENTRE OS PROPÓSITOS EPISTÊMICOS E AÇÕES TÍPICAS DO PROFESSOR COM OS ELEMENTOS DO TAP DOS ALUNOS}

Para auxiliar na identificação e na descrição das relações entre os propósitos epistêmicos e ações típicas do professor com os elementos do TAP dos alunos, elaboramos tabelas para identificar os turnos em que há relação direta entre um propósito epistêmico e ação típica e um elemento do TAP. O modelo de tabela é apresentado a seguir, com suas respectivas descrições (Tabela 1).

Tabela 1. Descrição dos constituintes dos resultados que identificam a localização das relações entre propósito epistêmico e ação típica com o elemento do TAP específico.

\begin{tabular}{|c|c|c|c|c|}
\hline \multicolumn{5}{|c|}{$\begin{array}{c}\text { PROPÓSITOS EPISTÊMICOS E AÇÕES TÍPICAS RELACIONADOS } \\
\text { À CONSTRUÇÃA DOS ELEMENTOS DO TAP }\end{array}$} \\
\hline $\begin{array}{l}\text { PROPÓSITO } \\
\text { EPISTÊMICO }\end{array}$ & $\begin{array}{c}\text { AÇÕES } \\
\text { TÍPICAS }\end{array}$ & INTERVALOS DE TURNOS & $\mathbf{N}$ & $\mathrm{F}(\%)$ \\
\hline $\begin{array}{l}\text { [Classificação } \\
\text { utilizada para } \\
\text { verificar que tipo } \\
\text { de propósito } \\
\text { epistêmico o } \\
\text { professor } \\
\text { utilizou]. }\end{array}$ & $\begin{array}{l}\text { [Ação por meio } \\
\text { da qual o } \\
\text { professor tenta } \\
\text { alcançar o } \\
\text { propósito } \\
\text { epistêmico]. }\end{array}$ & $\begin{array}{l}\text { [Apresentam dois turnos. O } \\
\text { primeiro turno representa a posição } \\
\text { onde foi classificada a fala do } \\
\text { professor. O segundo turno } \\
\text { representa a posição onde se } \\
\text { localiza a classificação atribuída na } \\
\text { fala do aluno]. }\end{array}$ & $\begin{array}{c}\text { [Indica } \\
\text { o } \\
\text { número } \\
\text { absoluto } \\
\text { de cada } \\
\text { intervalo } \\
\text { de } \\
\text { turno]. }\end{array}$ & $\begin{array}{l}\text { [Indica o } \\
\text { percentual } \\
\text { correspondente } \\
\text { para cada } \\
\text { intervalo de } \\
\text { turno]. }\end{array}$ \\
\hline
\end{tabular}

$\mathrm{Na}$ aula analisada, os propósitos epistêmicos retomar e explorar do professor mostraram-se associados com a construção do elemento "dado" pelo aluno. O propósito retomar foi encontrado na forma de ação típica retoma dado, enquanto que o propósito explorar foi encontrado na forma de ação típica explora ponto de vista, conforme apresentada na Tabela 2.

Tabela 2. Frequência de relações encontradas entre propósitos epistêmicos e ações típicas do professor com a construção dos dados dos argumentos.

\begin{tabular}{ccccc}
\multicolumn{5}{c}{ PROPOSITOS EPISTÉMICOS E AÇÕ ES TÍPICAS RELACIONADOS } \\
\multicolumn{5}{c}{ À CONSTRUÇÃO DO DADO } \\
\hline PROPÓSITO & AÇÕES & INTERVALOS DE TURNOS & N & F(\%) \\
EPISTÊMICO & TÍPICAS & & 02 & $20 \%$ \\
\hline Retomar & Retoma dado & $1-2 ; 106-107$ & $80 \%$ \\
Explorar & Explora ponto de & $7-8 ; 11-12 ; 34-35 ; 95-97 ; 165-166 ; 176-178 ;$ & 08 & $80 \%$ \\
& vista & $176-180 ; 183-184$ & \\
\hline
\end{tabular}

O professor utilizou a ação típica retoma dado quando teve por objetivo estimular os alunos a trazerem para a discussão dados já trabalhados em outros momentos. Por meio do propósito retomar o professor garantiu a tomada de consciência, das informações que poderiam construir dados dos seus argumentos. 
O professor utilizou a ação típica explora ponto de vista quando teve o objetivo de estimular os alunos a detalharem os dados observados. Uma forma de detalhar o dado referiu-se, por exemplo, à descrição do tamanho e da disposição das estruturas visualizadas no microscópio.

Para que os alunos pudessem construir "garantias" o professor fez uso principalmente dos propósitos epistêmicos retomar, explorar e qualificar. A tabela 3 apresenta a frequência de propósitos e ações associados à construção de garantias para os argumentos.

Tabela 3. Frequência de relações encontradas entre propósitos epistêmicos e ações típicas do professor com a construção das garantias dos argumentos.

\begin{tabular}{|c|c|c|c|c|}
\hline \multicolumn{5}{|c|}{$\begin{array}{l}\text { PROPÓSITOS EPISTÊMICOS E AÇÕES TÍPICAS RELACIONADOS } \\
\text { À CONSTRUÇÃO DA GARANTIA }\end{array}$} \\
\hline $\begin{array}{l}\text { PROPÓSITO } \\
\text { EPISTÊMICO }\end{array}$ & $\begin{array}{c}\text { AÇÕES } \\
\text { TÍPICAS }\end{array}$ & INTERVALOS DE TURNOS & $\mathbf{N}$ & $\mathbf{F}(\%)$ \\
\hline & Retoma conceito & $60-61 ; 156-157 ; 158-159 ; 227-228$ & 04 & 25 \\
\hline Retomar & $\begin{array}{l}\text { Retoma } \\
\text { informação }\end{array}$ & $144-145 ; 146-147$ & 02 & 12,5 \\
\hline Explorar & $\begin{array}{l}\text { Explora ponto de } \\
\text { vista }\end{array}$ & $\begin{array}{c}32-33 ; 76-77 ; 79-81 ; 158-159 ; 160-161 ; 160- \\
162\end{array}$ & 06 & 37,5 \\
\hline Qualificar & $\begin{array}{c}\text { Qualifica } \\
\text { variáveis, objetos } \\
\text { ou fenômenos }\end{array}$ & $56-57 ; 190-191 ; 192-193 ; 225-226$ & 04 & 25 \\
\hline
\end{tabular}

A retomada de informações feita pelo docente contribuiu para a construção das garantias dos ao trazer para a discussão com os alunos diferentes informações já trabalhadas anteriormente e necessárias para o estabelecimento de relações entre os dados e a conclusão.

A retomada de conceitos também foi essencial para auxiliar nesse sentido, especialmente porque a intenção do professor era construir juntamente com os alunos garantias pautadas nas características dos seres vivos.

O professor fez uso do propósito explorar, na forma de ação típica explora ponto de vista, o que auxiliou na construção daquelas garantias mais relacionadas a melhor observação do objeto de estudo e descrição dos dados (quando os alunos observaram melhor as características visualizadas no microscópio e a partir disso começam a inferir que tipo de estruturas são essas).

A ação típica qualifica variáveis, objetos ou fenômenos ligada ao propósito qualificar, auxiliou na seleção de elementos que deveriam ser privilegiados pelos alunos durante o processo de construção das garantias. O professor além de auxiliar os 
alunos a classificarem e caracterizarem os objetos, por meio de breves avaliações, também estimulou o uso de termos científicos adequados.

Durante a aula, a "conclusão" dos alunos foi favorecida graças ao propósito epistêmico problematizar isso em $100 \%$ dos casos observados (ver intervalos de turno 05-06, 78-79, 78-81 e 110-115). O propósito epistêmico problematizar foi encontrado na forma de ação típica propõe um problema.

Ao problematizar, o professor teve como objetivo tornar o objeto de estudo passível de investigação. As perguntas que conduziram a aula foram: A amostra contém seres vivos? Por quê? Explique. O objetivo da aula investigativa era a construção do argumento potencial: Dado que foram observados ao microscópio estruturas circulares (ou bolinhas). Já que essas bolinhas parecem ser células. E as células são as menores unidades morfofisiológicas que identificam seres vivos. Então, há seres vivos na amostra.

Também foi encontrado o elemento "refutação" na argumentação dos alunos. A refutação esteve mais relacionada aos propósitos epistêmicos retomar, explorar e qualificar. A tabela 4 apresenta a frequência de ações típicas associadas aos propósitos que promoveram a externalização de trechos classificadas como refutações.

Tabela 4. Frequência de relações encontradas entre propósitos epistêmicos e ações típicas do professor com a construção da refutação do argumento 01.

\begin{tabular}{|c|c|c|c|c|}
\hline \multicolumn{5}{|c|}{$\begin{array}{c}\text { PROPÓSITOS EPISTÊMICOS E AÇÕES TÍPICAS RELACIONADOS } \\
\text { À CONSTRUÇÃO DA REFUTAÇÃO }\end{array}$} \\
\hline $\begin{array}{c}\text { PROPÓSITO } \\
\text { EPISTÊMICO }\end{array}$ & $\begin{array}{c}\text { AÇÕOES } \\
\text { TÍPICAS }\end{array}$ & INTERVALOS DE TURNOS & $\mathbf{N}$ & $\mathbf{F}(\%)$ \\
\hline Retomar & $\begin{array}{c}\text { Retoma } \\
\text { informação }\end{array}$ & $36-37 ; 38-39$ & 02 & 28,6 \\
\hline Explorar & $\begin{array}{l}\text { Explora ponto de } \\
\text { vista }\end{array}$ & $17-18 ; 116-117$ & 02 & 28,6 \\
\hline \multirow[b]{2}{*}{ Qualificar } & $\begin{array}{l}\text { Qualifica } \\
\text { variáveis, objetos }\end{array}$ & $120-121$ & 01 & 14,2 \\
\hline & $\begin{array}{c}\text { ou fenômenos } \\
\text { Qualifica } \\
\text { explicações ou } \\
\text { pontos de vista }\end{array}$ & $19-20 ; 130-131$ & 02 & 28,6 \\
\hline
\end{tabular}

Durante a aula houve a construção de garantias errôneas e foi necessário que o docente causasse uma "desequilibração" de modo que os alunos abandonassem a premissa da motilidade e priorizassem a morfologia da amostra observada.

Assim, por exemplo, ao realizar a ação de retomada de informações e exploração do ponto de vista fazendo os alunos se lembrarem de exemplos de seres 
vivos que não se movimenta, o professor auxiliou a construção de refutadores para as garantias associadas à motilidade.

Por fim, o professor também fez uso do propósito qualificar para auxiliar os alunos a construírem o elemento refutação. O professor executou breves avaliações justamente com a finalidade de que os alunos descartassem dados e garantias que faziam referência a essa questão da motilidade.

Embora não tenham sido encontradas relações entre o propósito sintetizar e suas ações com os elementos do TAP, ressaltamos a importância desse propósito quanto o papel de organizar os conceitos trazidos ao longo de toda a aula. Como já afirmado anteriormente, os propósitos epistêmicos qualificar e sintetizar além de avaliar as falas dos alunos, atuaram na finalização da aula com a sistematização do argumento 02 da aula.

\subsection{CONSIDERAÇÕES FINAIS}

Após a discussão acima, sintetizamos que:

1) Existe uma relação entre o propósito epistêmico problematizar, ligado à ação típica propõe um problema, com a construção de conclusões em atividades argumentativas. O objetivo do professor em apresentar o problema "se havia seres vivos na amostra desconhecida" foi de estimular a defesa de posicionamentos pelos alunos.

2) Há relação entre a ação típica retomada de dados com a construção de dados. Os dados foram levantados após observação no microscópio da amostra e dos materiais utilizados. Contudo, o professor também fez uso da ação típica explora ponto de vista para averiguar a compreensão dos alunos sobre as características do objeto de estudo observadas, como, por exemplo, o formato de uma célula.

3) Há relação entre a ação típica retomada de conceitos e a construção de garantias. A retomada de conceitos foi necessária quando o professor quis que os alunos construíssem o conceito de célula, que se adequaria para estabelecer a relação entre dado e conclusão. Vale salientar que a construção das garantias também foi favorecida pelas ações típicas qualifica variáveis, objetos ou fenômenos e explora ponto de vista e pelo propósito epistêmico sintetizar. 
4) A última relação destacada é entre a ação típica qualifica explicações ou pontos de vista e a construção de refutações. 


\section{CAPÍTULO 5 - CONCLUSÕES}

Este trabalho partiu da seguinte questão de pesquisa: Como os propósitos epistêmicos e as ações típicas do professor contribuem para a argumentação oral dos alunos durante uma aula investigativa de ciências? Apresentamos a seguir

algumas conclusões e implicações para o ensino e para a pesquisa em ensino de Ciências.

$\mathrm{Na}$ Introdução defendemos que o ensino de Ciências tem o objetivo central de promover a alfabetização cientifica dos alunos e que um dos papéis do professor que favorece esse processo é criar um ambiente interativo de argumentação colaborativa dentro da sala de aula.

No capítulo 01 apresentamos a abordagem do ensino por investigação e as características de sequências didáticas investigativas, defendendo que estas contribuem para estimular os alunos a argumentarem. Em seguida, discutimos algumas ferramentas que analisam a mediação do professor em aulas investigativas e justificamos a adoção do instrumento propósitos epistêmicos e ações típicas do professor.

No capítulo 02 a discussão sobre argumentação e sua importância para o ensino de Ciências é ampliada e justificamos a adoção de outra ferramenta analítica - o layout de Toulmin, voltado para a identificação de argumentos.

No capítulo 03 apresentamos detalhes da metodologia utilizada e no capítulo 04 discutimos os principais resultados encontrados. Os dados foram obtidos por meio da análise de uma atividade educativa realizada no programa Mais Educação em uma escola pública do interior do Estado de São Paulo. Analisamos a mediação do professor por meio dos propósitos epistêmicos e ações típicas e os associamos com a construção dos elementos do layout de argumento de Toulmin.

Os propósitos epistêmicos explorar e qualificar foram os mais frequentes. A maior frequência desses propósitos deveu-se ao esforço do professor em levar os alunos a avaliarem as garantias que estavam utilizando para a construção de suas conclusões sobre a presença de seres vivos na amostra analisada.

Os propósitos epistêmicos explorar e qualificar foram importantes para estimular os alunos a reavaliarem a presença de movimento como uma característica obrigatória dos seres vivos, levando-os a discutir um critério mais abrangente (que envolve a teoria celular). 
A ferramenta de Ferraz e Sasseron (2014) e Ferraz (2015), assim como, a de Sasseron e Carvalho (2013) não foram criadas com a intenção de averiguar um par de ação e de reação entre professor e aluno, mas sim de compreender como as interações permitem com que as falas desses sujeitos sejam construídas concatenadamente.

Contudo, em nossa pesquisa foram observadas relações entre: I) propósito epistêmico retomar ligado à ação de retomada de dado e o elemento dado do TAP; II) propósito problematizar ligado à ação de propor um problema e a conclusão do TAP; III) propósito epistêmico qualificar ligado à ação qualifica explicações ou pontos de vista e o elemento refutação do TAP e; IV) propósito epistêmico retomar ligado à ação retomada de conceito e o elemento garantia do TAP.

O propósito sintetizar foi registrado predominante no final da aula e teve o papel de organizar as informações trazidas pelos alunos que estariam coerentes com o objetivo da aula. Diferente dos outros, esse propósito não mostrou uma associação clara com nenhum elemento do TAP. Mas devemos destacar que a maioria das falas do professor que foram classificadas como possuindo o propósito sintetizar também foram classificadas como qualificar. Isso significaria que o professor, além de avaliar/classificar aquilo que foi falado pelos alunos, organiza as informações que considera coerentes com a proposta da atividade para socializar a produção coletiva (socializar o argumento produzido de maneira colaborativa ao longo da aula).

Reconhecemos que a frequência de propósitos epistêmicos e de ações típicas foram maiores que a frequência de elementos do TAP. Esse fato nos faz pensar que não é um determinado propósito epistêmico ligado a uma ação típica que culmina com a construção de um elemento do TAP, mas sim um conjunto de propósitos e ações.

$\mathrm{O}$ presente trabalho permitiu repensar sobre o papel da pesquisa em argumentação nas salas de aula de Ciências para a formação de professores.

Tradicionalmente o preparo dos professores se dá por transmissão de conteúdos específicos, acrescidos de uma instrumentação pedagógica e uma prática de ensino ao final do curso (OLIVEIRA; LUDKE, 2011). É notório a presença de um modelo de formação inspirada em racionalidade técnica, na qual disciplinas específicas e pedagógicas não dialogam. Afinal, geralmente as disciplinas pedagógicas são ministradas por profissionais ligados a departamentos ou centros de educação, classificados como aqueles que "preparam" o professor, e as disciplinas específicas são aquelas que "preparam” pesquisadores (ARAÚJO; FRANÇA, 2010). 
Em oposição à formação descrita anteriormente, há um movimento para formação de professores que sejam consumidores críticos de pesquisa no campo do ensino de Ciências, bem como tornar possível que esses professores em formação sejam participantes de projetos de pesquisa, seja como sujeito de investigação ou como pesquisador. Vale salientar que a pesquisa a ser desenvolvida no contexto de formação de professores depende dos objetivos da pesquisa e dos modos como a pesquisa é conduzida pelos educandos ao longo do curso de graduação ou de pós-graduação (ARAÚJO; FRANÇA, 2010).

O professor investigado em nosso trabalho corresponde com os aspectos indicados acima. O professor pesquisado é pós-graduando na área de ensino de Ciências e participa do grupo de pesquisa LINCE, que é interessada em desenvolver estratégias que privilegiem a $\mathrm{AC}$ dos alunos, principalmente por meio da promoção da argumentação na sala de aula. Em suma, a prática docente do sujeito investigado se alinha aos seus próprios interesses de pesquisa.

Neste sentido, consideramos importante o papel da pesquisa na formação de professores de Ciências. Além de permitir melhorias na prática docente, permite o professor a participar de pesquisas que os aproximem da prática de produção do conhecimento científico e, assim, desenvolver algumas atitudes e habilidades de um pesquisador, como a curiosidade, a observação, o senso crítico e outras - atividades estas necessárias também para o professor (ARAÚJO; FRANÇA, 2010). 


\section{REFERÊNCIAS}

ARAÚJO, M. L. F.; FRANÇA, T. L. A pesquisa na formação inicial de professores de Biologia. Polyphonía, v. 21, n. 1, 201-215, 2010.

AULER, D. Alfabetização científico-tecnológica: um novo "paradigma"? Ensaio Pesquisa em Educação em Ciências, v. 5, n. 1, p. 68-83, 2003.

AULER, D.; DELIZOICOV, D. Alfabetização Científico-Tecnológica Para Quê? Ensaio - Pesquisa em Educação em Ciências, v.3, n.1, p. 1-13, 2001.

BARTH-TEIXEIRA, E. A análise dos dados na pesquisa científica: importância e desafios em estudos organizacionais. Desenvolvimento em Questão, v.1, n. 2, p. 177201, 2003.

BRANDI, A.; GURGEL, C. A. Alfabetização Científica e o processo de ler e escrever em séries iniciais: emergências de um estudo de investigação. Ciência \&Educação, v.8, n.1, p. 113-12, 2002.

BRASIL. Parâmetros Curriculares Nacionais: Ciências Naturais/Secretaria de Educação Fundamental. Brasília: MEC/SEF, 1998.

BRICKER, L. A.; BELL, P. Argumentation and reasoning in life and in school: implications for the design of school science learning environments. In: KHINE, M. S. (Ed.). Perspectives on scientific argumentation: Theory, practice, and research. Dordrecht, The Netherlands: Springer, 2012. 117-133 p.

CARVALHO, A. M. P. Ensino e aprendizagem de ciências: referenciais teóricos e dados empíricos das sequências de ensino investigativo (SEI). In: LONGHINI, M. D. (Org.). O uno e o diverso na educação. Uberlândia, MG: EDUFU, 2011. 253-266 p.

CARVALHO, A. M. P. O ensino de Ciências e a proposição de sequências de ensino investigativas. In: CARVALHO, A. M. P. (Org.) Ensino de Ciências por Investigação - Condições para implementação em sala de aula. São Paulo: Cengage Learning, 2013. $1-20 \mathrm{p}$.

CHASSOT, A. Alfabetização científica e cidadania. In: CHASSOT, A. Alfabetização científica: questões e desafios para a educação. Ijuí: Editora Unijuí, 2000. 27-48 p.

DRIVER, R.; NEWTON, P.; OSBORNE, J. Establishing the norms of scientific argumentation in classrooms. Science Education, v. 84, n. 3, p. 287-312, 2000.

ERDURAN, S.; SIMON, S.; OSBORNE, J. TAPping into argumentation: developments in the application of Toulmin's Argument Pattern for studying science discourse. Science Education, v. 88, n. 6, p. 915-933, 2004.

FERRAZ, A. T.; SASSERON, L. H. Propósitos epistêmicos para promoção da argumentação em aulas investigativas de física. In: XV Encontro de Pesquisa em Ensino de Física, Maresias, 2014. 8 p. 
FERRAZ, A. T. Propósitos epistêmicos para a promoção da argumentação em aulas investigativas de física. Dissertação (Mestrado) - Universidade de São Paulo. Faculdade de Educação, Instituto de Física, Instituto de Química e Instituto de Biociências. 175 p. 2015.

FLICK, U. Introdução à Pesquisa Qualitativa. Trad. Joice Elias Costa. $3^{\text {a }}$ Edição. Porto Alegre: Artmed, 2009.

GARCÍA-DE-CAJÉN, S.; DOMÍNGUEZ-CASTIÑEIRAS, J. M.; GARCÍA-RODEJA FERNÁNDEZ, E. Razonamiento y argumentación em ciencias. Diferentes puntos de vista en el currículo oficial. Enseñanza de las Ciencias, v. 20, n. 2, p. 217-228, 2002.

JIMÉNEZ-ALEIXANDRE, M. P. Diseño Curricular: Indagación y Racionamiento con el lenguaje de las Ciencias. Enseñanza de las Ciencias, v. 16, n. 2, p. 203-216, 1998.

JIMÉNEZ-ALEIXANDRE, M. P.; BUGALLO-RODRÍGUEZ, A.; DUSCHL, R. A. "Doing the Lesson" or "Doing Science": Argument in High School Genetics. Science Education, v.84, n. 6, p. 757-792, 2000.

JIMÉNEZ-ALEIXANDRE, M. P.; DÍAZ DE BUSTAMANTE, J. Discurso de Aula y Argumentación en la Clase de Ciências: Cuestiones Teóricas y Metodológicas. Enseñanza de las Ciencias, v. 21, n.3, p. 359-370, 2003.

JIMÉNEZ-ALEIXANDRE, M. P.; AGRASO, M. F. A argumentação sobre questões sóciocientíficas: processos de construção e justificação do conhecimento em sala de aula. Educação em Revista, v. 43, p. 13-33, 2006.

KELLY, G. J.; DRUKER, S.; CHEN, C. Students reasoning about eletricity: combining performance assessments with argumentation analysis. International Journal of Science Education, v. 20, n. 7, p. 849-871, 1998.

KUHN, D. Science as argument: Implications for teaching and learning scientific thinking. Science Education, v. 77, n. 3, p. 319-337, 1993.

LAHORE, A. Lenguaje literal y connotado en la ensenãnza de las ciencias. Ensenãnza de las Ciencias, v.11, n. 1, p. 59-62, 1993.

LAUGKSCH, R. C. Scientific Literacy: A conceptual Overview. Science Education, v. 84, p. 71-94, 2000.

LEITÃO, S. O lugar da argumentação na construção do conhecimento em sala de aula. In: LEITÃO, S.; DAMIANOVIC, M. C. (Orgs.). Argumentação na Escola: o conhecimento em construção. Campinas: Pontes Editores, 2011. 13-46 p.

LIDAR, M.; LUNDQVIST, E.; OSTMAN, L. Teaching and learning in the science classroom: the interplay between teachers epistemological moves and students practical epistemology. Science Education, v. 90, n. 1, p. 148-163, 2006.

LORENZETTI, L.; DELIZOICOV, D. Alfabetização Científica no contexto das séries iniciais. Ensaio - Pesquisa em Educação em Ciências, v.3, n.1, p. 1-17, 2001. 
LUDKE, M.; ANDRÉ, M. E. D. A. Pesquisa em educação: abordagens qualitativas. São Paulo: EPU, 1986.

MORTIMER, E. F.; SCOTT, P. H. Atividade discursiva nas salas de aula de ciências: uma ferramenta sociocultural para analisar e planejar o ensino. Investigações em Ensino de Ciências, v. 7, n. 3, p. 203-306, 2002.

MORTIMER. E. F.; SCOTT, P. H. Meaning making in secondary science classroom. Maidenhead: Open University Press/ McGraw Hill Education, 2003.

MOTOKANE, M. T. Sequências didáticas investigativas e argumentação no ensino de ecologia. Ensaio, v. 17, n. especial, p. 115-137, 2015.

NASCIMENTO, S. S.; VIEIRA, R. D. Contribuições e limites do padrão de argumento de Toulmin aplicado em situações argumentativas de sala de aula de ciências. Revista Brasileira de Pesquisa em Educação em Ciências, v. 8, n. 2, p. 1-20, 2008.

NRC. Introduction. NRC (National Research Council). National Science Education Standards. Washington: National Academy Press, 1996. 14-17 p.

OLIVEIRA, S. S.; LUDKE, M. Qual o lugar da pesquisa na formação de professores de Ciências? In: VIII ENPEC - Encontro Nacional de Pesquisa em Educação em Ciências, 2011, Campinas. VIII ENPEC, 2011, p. 1-13.

OSBORNE, J.; ERDURAN, S.; SIMON, S. Enhancing the quality of argumentation in school science. Journal of Research in Science Teaching, v. 41, n. 10, p. 994-1020, 2004.

PRETI, D. Apresentação. In: PRETI, D. (Org.). Análise de textos orais. $4^{a}$ Edição. São Paulo: Humanitas Publicações FFLCH/USP, 1999. 7-12 p.

RATZ, S. V. S.; MOTOKANE, M. T. A construção de um argumento em uma sequência didática aplicada a professores de ciências e biologia. Revista da SBenBio, n. 7, p. 6232-6241, 2014.

SADLER, T. D. Promoting discourse and argumentation in science teacher education. Journal of Science Teacher Education, v. 17, n. 4, p. 323-346, 2006.

SARDÀ-JORGE, A.; SANMARTÍ-PUIG, N. Enseñar a argumentar cientificamente: um reto de las clases de ciencias. Enseñanza de las ciencias, v. 18, n. 3, p. 405-422, 2000.

SASSERON, L. H. Alfabetização científica, ensino por investigação e argumentação: relações entre ciências da natureza e escola. Ensaio, v. 17, n. especial, p. 49-67, 2015.

SASSERON, L. H.; CARVALHO, A. M. P. Almejando a alfabetização científica no ensino fundamental: a proposição e a procura de indicadores do processo. Investigações em Ensino de Ciências, Porto Alegre, v. 13, n. 3, p. 333-352, 2008. 
SASSERON, L. H. CARVALHO, A. M. P. Construindo argumentação na sala de aula: a presença do ciclo argumentativo, os indicadores de alfabetização científica e o padrão de Toulmin. Ciência \& Educação, v. 17, n. 1, p. 97-114, 2011.

SASSERON, L. H.; CARVALHO, A. M. P. Alfabetização científica: uma revisão bibliográfica. Investigações em Ensino de Ciências, v. 16, n.1, p. 59-77, 2011.

SASSERON, L. H. Interações discursivas e investigação em sala de aula: o papel do professor. In: CARVALHO, A. M. P. (Org.). Ensino de Ciências por Investigação Condições para implementação em sala de aula. São Paulo: Cengage Learning, 2013, p. 41-61.

SASSERON, L. H.; CARVALHO, A. M. P. Ações e indicadores da construção do argumento em aula de ciências. Revista Ensaio, v. 15, n. 2, p. 169-189, 2013.

SIMON, S.; ERDURAN, S.; OSBORNE, J. Learning to Teach Argumentation: Research and Development in the Science Classroom. International Journal of Science Education, n. 28. p. 235-260, 2006.

SMART, J. B.; MARSHALL, J. C. Interactions between classroom discourse, teacher questioning, and student cognitive engagement in middle school science. Journal of Science Teacher Education, v. 24, n. 2, p. 249-267, 2012.

SILVA, A. C. T. Interações discursivas e práticas epistêmicas em salas de aula de Ciências. Ensaio, v. 17, n. especial, p. 69-96, 2015.

SUTTON, C. Los professores de ciencias como professores de lenguaje. Enseñanza de las Ciencias, v. 21, n. 1, p. 21-25, 2003.

TOULMIN, S. E. O layout de argumento. In: TOULMIN, S. E. Os usos do argumento. $2^{\mathrm{a}}$ Edição. São Paulo: Martins Fontes, 2006. 135-207 p.

VIECHENESKI, J. P.; CARLETTO, M. R. Ensino de Ciências e Alfabetização Científica nos anos iniciais do Ensino Fundamental: um olhar sobre as escolas públicas de Carambeí. In: Anais do VIII Encontro Nacional de Pesquisa em Ensino de Ciências, Campinas, 2011. 12 p.

VILLANI, C. E. P.; NASCIMENTO, S. S. A Argumentação e o Ensino de Ciências: Uma Atividade Experimental no Laboratório Didático de Física do Ensino Médio Investigações em Ensino de Ciências, v. 8, n. 3, p. 187-209, 2003. 


\section{ANEXO A}

\section{Atividade 1 - Observando micro-organismos (Parte 1)}

Bulma é uma cientista brilhante que trabalha na Corporação Capsula, uma grande empresa no desenvolvimento de tecnologias importantes. Recentemente, Bulma estava estudando micro-organismos que ajudam na fabricação de alimentos humanos, mas durante um de seus experimentos, ela acabou misturando o pote que continha esses seres vivos a outros potes contendo outros tipos de materiais. Como todos os potes estão sem rótulos, Bulma não sabe mais qual o conteúdo de cada pote.

Agora, você também poderá trabalhar como cientista e ajudá-la a solucionar o problema:

i) Qual é, provavelmente, o pote que contém os seres vivos? Explique como chegou à sua resposta.

Cientistas tem um jeito particular para solucionar problemas.

A) Primeiramente, é preciso fazer uma lista de materiais (ferramentas ou instrumentos) necessários à investigação, escreva abaixo a sua lista de materiais.

B) Em seguida, é preciso descrever detalhadamente cada passo ou etapa a ser realizada até a resolução final do problema, ou seja, descrever como cada material será utilizado, por exemplo, "qual a quantidade necessária de cada material?", “em qual momento da investigação eles serão usados e de que maneira?".

Descreva abaixo todos os passos da sua investigacão (é como ter que escrever uma receita de bolo e contar passo a passo tudo que é necessário fazer até o bolo ficar pronto): 
C) Finalmente, é preciso executar todos os passos planejados e ir registrando os principais acontecimentos ou resultados observados durante a investigação; comente as suas principais observações:

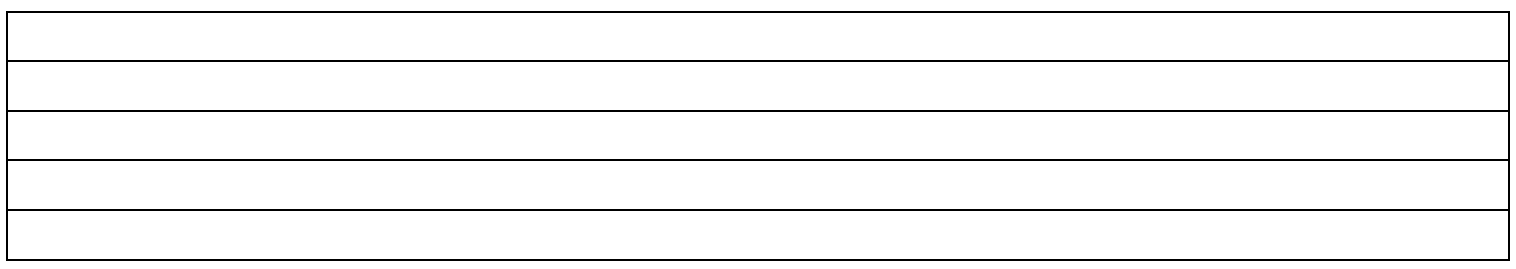

Para agir como um cientista, você deve trabalhar dessa maneira, registrando todos os passos de sua investigação, pois um dia se outros pesquisadores precisarem resolver um problema parecido, eles já terão um roteiro ou plano do que fazer, ou ainda, se a cientista Bulma duvidar dos resultados encontrados, ela mesma poderá repetir a investigação seguindo o mesmo roteiro (ou mesmos passos) para provar se a conclusão que você elaborou é realmente confiável. 


\section{APÊNDICE A}

\section{Lista de Orientações para Aplicação da Atividade Investigativa}

Para realizar a aula investigativa, é necessário conter os seguintes materiais (Quadro 01).

Quadro 01. Lista de Materiais (ferramentas ou instrumentos) necessários para investigação.

3 colheres de chá do material desconhecido proveniente do pote " $\mathrm{x}$ ". (Total: 4 potes); Não se esquecer de fazer teste-controle;

1 frasco maior de, no mínimo, $200 \mathrm{~mL}$ (5 de cada);

Água fria;

1 lâmina e 1 lamínula (5 de cada);

1 microscópio;

1 colher ou 1 bastão de vidro;

1 canudo ("pipeta") (5 de cada);

1 câmera fotográfica digital.

Sugere-se que o professor organize a sala de modo a formar grupos de 4 a 5 alunos. O professor deve iniciar a aula indagando com os alunos se a amostra proveniente no pote é um ser vivo ou não. Em seguida, após apresentação das concepções prévias dos alunos, o professor deve explicar sobre a prática dos cientistas quanto à construção de evidências. Assim, o professor deve realizar a série de procedimentos destacado no Quadro 02.

Quadro 02. Lista de Procedimentos (ferramentas ou instrumentos) necessários para investigação.

1) Preparar a suspensão do material " $x$ ", colocando 1 colher de chá no frasco maior e dissolvendo-o em $200 \mathrm{~mL}$ de água fria, com auxilio da colher ou bastão de vidro;

2) Identificar a lâmina com a letra ou número "x";

3) Usar o canudo como pipeta para colocar uma gota em suspensão na respectiva lâmina e cobri-la com a lamínula;

4) Observar a lâmina ao microscópio e tirar uma foto para comparar com as lâminas contendo outros materiais desconhecidos.

Assim que as lâminas estiverem prontas, apresentar para os alunos para que observem no microscópio. Em seguida, sugere-se que façam as seguintes perguntas:

1. O que foi observado na amostra?

2. Baseado nessa observação, essa amostra contém seres vivos ou não?

3. Por que você (o aluno) acha que a amostra contém (ou não contém) seres vivos? Peça para que o aluno explique. 
O objetivo dessa aula é que os alunos apresentem evidências e conclusões sobre a presença ou não de seres vivos na amostra e que construíssem alguma garantia que justificasse às suas alegações. 


\section{APÊNDICE B}

Tabela 5. Frequência de ações típicas ocorrida na aula.

\begin{tabular}{lcc}
\hline AÇÕES TÍPICAS & N & \% \\
\hline Retoma conceitos & 3 & 2,4 \\
Retoma dados & 9 & 7,1 \\
Retoma informações & 17 & 13,4 \\
Propõe um problema & 4 & 3,1 \\
Explora ponto de vista & 25 & 19,7 \\
Explora condições de investigação & 10 & 7,9 \\
Qualifica variáveis, objetos ou fenômenos & 33 & 26,0 \\
Qualifica explicações ou pontos de vista & 12 & 9,4 \\
Qualifica contexto de investigação & 3 & 2,4 \\
Sintetiza informações & 6 & 4,7 \\
Sintetiza explicações & 5 & 3,9 \\
\hline TOTAL & 127 & 100 \\
\hline
\end{tabular}

Tabela 6. Frequência de elementos do TAP encontradas na aula.

\begin{tabular}{lcc}
\hline ELEMENTO DO TAP & N & \% \\
\hline Dado & 10 & 24,4 \\
Garantia & 19 & 46,3 \\
Refutação & 8 & 19,5 \\
Conclusão & 4 & 9,8 \\
\hline TOTAL & 41 & 100 \\
\hline
\end{tabular}




\section{APÊNDICE C}

Quadro 14. Transcrição de falas da aula e classificações feitas para os propósitos epistêmicos e ações típicas do professor e os elementos do TAP construídos pelos alunos.

\begin{tabular}{|c|c|c|c|c|c|}
\hline TURNO & SUJEITO & FALA & $\begin{array}{l}\text { PROPÓSITO } \\
\text { EPISTÊMICO }\end{array}$ & AÇÃO TÍPICA & TAP \\
\hline 01 & $\mathrm{P}$ & O que é que você viu? O que você viu assim? & Retomar & Retoma dados & \\
\hline 02 & A16 & $\begin{array}{l}\text { Eu vi um negócio assim pequenininho ((com uma das mãos, ele gesticula que } \\
\text { visualizou algo muito pequeno)) Vários assim! ((gesticula as mãos em direções } \\
\text { opostas)). }\end{array}$ & & & Dado \\
\hline 03 & $\mathrm{P}$ & Ah é? Muitos? & Qualificar & $\begin{array}{l}\text { Qualifica variáveis, } \\
\text { objetos ou fenômenos }\end{array}$ & \\
\hline 04 & A16 & É. & & & \\
\hline 05 & $\mathrm{P}$ & E, quê que você acha que ele tá vivo ou não? & Problematizar & Propõe um problema & \\
\hline 06 & A16 & Não! Não tá vivo não! & & & Conclusão \\
\hline 07 & $\mathrm{P}$ & Ce acha que não tá vivo? (...) Por que você acha que não tá vivo? & Explorar & Explora ponto de vista & \\
\hline 08 & A16 & Porque eles não estavam se mexendo. & & & Dado \\
\hline 09 & $\mathrm{P}$ & Eles não estavam se mexendo? & Explorar & Explora ponto de vista & \\
\hline 10 & A16 & Não! & & & \\
\hline 11 & $\mathrm{P}$ & Então, você acha que para estar vivo, o mais importante é ter que ver mexer? & Explorar & Explora ponto de vista & \\
\hline 12 & A16 & $\begin{array}{l}\text { Não! (...) Não! Ele era bem pequenininho... ((com uma das mãos, ele gesticula que } \\
\text { visualizou algo muito pequeno)) E eles não estavam movimentando nada! Estavam } \\
\text { parados ((bate palma seguindo um movimento descendente, isto é, de cima pra } \\
\text { baixo)). }\end{array}$ & & & Dado \\
\hline 13 & $\mathrm{P}$ & Hã? & & & \\
\hline 14 & A16 & $\begin{array}{l}\text { Não tava movendo nada! Tava parado! Pá! ((bate palma seguindo um movimento } \\
\text { descendente, isto é, de cima pra baixo)). }\end{array}$ & & & Dado \\
\hline 15 & $\mathrm{P}$ & Tava parado! Legal! Cê acha que tem alguma forma para saber se tá vivo? & Explorar & $\begin{array}{l}\text { Explora condições de } \\
\text { investigação }\end{array}$ & \\
\hline 16 & A16 & Hum... (...) Tem! & & & \\
\hline 17 & $\mathrm{P}$ & $\begin{array}{l}\text { Eu acho que a próxima coisa que o professor } \mathrm{P} \text { vai tentar fazer. Que dará pra ver se tá } \\
\text { ou não vivo! Porque tem coisa que não mexe, né? Por exemplo, a árvore, a árvore não } \\
\text { se mexe, né? }\end{array}$ & $\begin{array}{l}\text { Qualificar } \\
\text { Explorar }\end{array}$ & $\begin{array}{l}\text { Qualifica explicações } \\
\text { ou pontos de vista } \\
\text { Explora ponto de vista }\end{array}$ & \\
\hline 18 & A16 & Mas é viva! & & & Refutação \\
\hline 19 & $\mathrm{P}$ & Mas tá viva, né? Também tá parada! Então nem tudo que tá parado... & Qualificar & Qualifica explicações & \\
\hline
\end{tabular}




\begin{tabular}{|c|c|c|c|c|c|}
\hline & & & & ou pontos de vista & \\
\hline 20 & A16 & $\begin{array}{l}\text { Aqui na área dá pra ver que as árvores tão se mexendo por causa do vento, mas elas } \\
\text { estão vivas. Não é? Elas não estão vivas? Olha pra lá ((apontando para o jardim)), } \\
\text { filma lá! Tá tudo vivo! }\end{array}$ & & & Refutação \\
\hline 21 & $\mathrm{P}$ & $\begin{array}{l}\text { Eles estão vivos né? A gente pensa assim que tudo que é vivo mexe! Mas, e a árvore? } \\
\text { A árvore é viva e não se mexe. Complicado isso, né? }\end{array}$ & Qualificar & $\begin{array}{l}\text { Qualifica explicações } \\
\text { ou pontos de vista }\end{array}$ & \\
\hline 22 & A16 & [Inaudível] & & & \\
\hline 23 & $\mathrm{P}$ & $\begin{array}{l}\text { Mas há outras coisas que podem dizer que é um ser vivo, né? (...) A gente vai ter que } \\
\text { pensar nisso! Porque eu acho que a próxima pergunta que o professor P vai fazer é: } \\
\text { como a gente vai fazer para saber se está vivo ou não? }\end{array}$ & $\begin{array}{l}\text { Qualificar } \\
\text { Explorar }\end{array}$ & $\begin{array}{l}\text { Qualifica explicações } \\
\text { ou pontos de vista } \\
\text { Explora condições de } \\
\text { investigação }\end{array}$ & \\
\hline 24 & A16 & $\begin{array}{l}\text { Então eu vou esperar, porque bate um nervoso aqui ((toca o próprio peito com as duas } \\
\text { mãos)). }\end{array}$ & & & \\
\hline 25 & $\mathrm{P}$ & Por exemplo, o que tá vivo se alimenta? & Explorar & Explora ponto de vista & \\
\hline 26 & A16 & Hum! Se alimenta! & & & \\
\hline 27 & $\mathrm{P}$ & Se alimenta. Será que vai ter como ver se aquilo ali tá se alimentando? & Explorar & $\begin{array}{l}\text { Explora condições de } \\
\text { investigação }\end{array}$ & \\
\hline 28 & A16 & Vai! [Inaudível] & & & \\
\hline 29 & $\mathrm{P}$ & Então, a gente vai ter que pensar isso depois! & & & \\
\hline 30 & A16 & Eu vou repetir isso de novo ((aluno A4 observa as células no microscópio)). & & & \\
\hline 31 & A13 & Eu vi um negócio assim! & & & \\
\hline 32 & $\mathrm{P}$ & O quê você acha que são essas bolinhas, hein? & Explorar & Explora ponto de vista & \\
\hline 33 & A14 & Acho que são bactérias. & & & Garantia \\
\hline 34 & $\mathrm{P}$ & Você acha que são bactérias? & Explorar & Explora ponto de vista & \\
\hline 35 & A14 & $\begin{array}{l}\text { Elas estavam grudadas assim, mais ou menos ((aluno A14 usam o indicador querendo } \\
\text { representar que as bolinhas estavam enfileiradas)). }\end{array}$ & & & Dado \\
\hline 36 & $\mathrm{P}$ & Tavam grudadas? & Explorar & $\begin{array}{l}\text { Explora condições de } \\
\text { investigação }\end{array}$ & \\
\hline 37 & A14 & $\begin{array}{l}\text { ((aluno A14 gesticula cabeça no sentido de corroborar com a fala e a pergunta } \\
\text { anteriores }))\end{array}$ & & & \\
\hline 38 & $\mathrm{P}$ & Todo mundo já olhou? & & & \\
\hline 39 & A3 & Não! ((aluno A3 movimenta o dedo indicador gesticulando negação)). & & & \\
\hline 40 & $\mathrm{P}$ & Eu quero perguntar o que vocês estão vendo... & Retomar & Retoma dados & \\
\hline 41 & An & [Inaudível] & & & \\
\hline 42 & $\mathrm{P}$ & Eu quero saber o que são essas bolinhas... & Explorar & Explora ponto de vista & \\
\hline
\end{tabular}




\begin{tabular}{|c|c|c|c|c|c|}
\hline 43 & An & [Inaudível] & & & \\
\hline 44 & $\mathrm{P}$ & Psiu::: & & & \\
\hline 45 & A15 & Tá branco! Tô tentando achar! & & & \\
\hline 46 & $\mathrm{P}$ & Então, como é que tá? & & & \\
\hline 47 & An & [Inaudível] & & & \\
\hline 48 & $\mathrm{P}$ & Psiu::: Quem já viu, deixa o colega também ver. & & & \\
\hline 49 & An & [Inaudível] & & & \\
\hline 50 & $\mathrm{P}$ & Deixa quem não viu, agora ver! & & & \\
\hline 51 & A15 & Eu to vendo só coisa branca aqui, não consigo ver nada! & & & \\
\hline 52 & $\mathrm{P}$ & Não, mas tava ótimo! Você me mostrou. & & & \\
\hline 53 & A13 & Tio, eu tava vendo um monte de coisas ali... & & & \\
\hline 54 & $\mathrm{P}$ & O que você acha? Diz aí o que você acha que são aquelas bolinhas. & Qualificar & $\begin{array}{l}\text { Qualifica variáveis, } \\
\text { objetos ou fenômenos }\end{array}$ & \\
\hline 55 & A13 & Ah, nem pode ver! & & & \\
\hline 56 & $\mathrm{P}$ & O que vem à sua imaginação? (...) Várias bolinhas. Na sua cabeça, o que é que é? & Qualificar & $\begin{array}{l}\text { Qualifica variáveis, } \\
\text { objetos ou fenômenos }\end{array}$ & \\
\hline 57 & A14 & Célula. & & & Garantia \\
\hline 58 & $\mathrm{P}$ & Hã?! & & & \\
\hline 59 & A14 & $\begin{array}{l}\text { É:::: ((aluno A14 gesticula com o polegar e o dedo indicador o tamanho da estrutura } \\
\text { observada)) }\end{array}$ & & & \\
\hline 60 & $\mathrm{P}$ & O que você disse? & Retomar & Retoma conceito & \\
\hline 61 & A14 & Célula. & & & Garantia \\
\hline 62 & $\mathrm{P}$ & Células? & Explorar & Explora ponto de vista & \\
\hline 63 & A14 & É. & & & \\
\hline 64 & $\mathrm{P}$ & $\begin{array}{l}\text { Onde você já ouviu essa palavra? Onde você já ouviu essa palavra? Cê ouviu essa } \\
\text { palavra de algum lugar. Foi na escola? }\end{array}$ & Retomar & Retoma informações & \\
\hline 65 & A14 & ((aluno A15 gesticula cabeça no sentido de afirmar a pergunta anterior do professor)) & & & \\
\hline 66 & A15 & Que palavra que ele falou? & & & \\
\hline 67 & $\mathrm{P}$ & Células. & Retomar & Retoma informações & \\
\hline 68 & A15 & É. & & & \\
\hline 69 & $\mathrm{P}$ & Já ouviram falar aqui na escola? & Retomar & Retoma informações & \\
\hline 70 & A15 & Não! & & & \\
\hline 71 & $\mathrm{P}$ & Então aonde foi? & Retomar & Retoma informações & \\
\hline 72 & A15 & Acho que foi na sala de aula. & & & \\
\hline 73 & A16 & Já ouvi! & & & \\
\hline
\end{tabular}




\begin{tabular}{|c|c|c|c|c|c|}
\hline 74 & $\mathrm{P}$ & Já ouviu essa palavra? & Retomar & Retoma informações & \\
\hline 75 & A14 & Já! & & & \\
\hline 76 & $\mathrm{P}$ & E o que você acha que seja célula? & Explorar & Explora ponto de vista & \\
\hline 77 & A13 & Professor, eu acho que são umas criaturas... & & & Garantia \\
\hline 78 & $\mathrm{P}$ & Tirando a água daí, você acha que tem ser vivo ou não? & Problematizar & Propõe um problema & \\
\hline 79 & A14 & Eu acho que tem. & & & Conclusão \\
\hline 80 & $\mathrm{P}$ & Por que você acha que tem? & Explorar & Explora ponto de vista & \\
\hline 81 & A13 & Eu acho que não... & & & Conclusão \\
\hline 82 & A14 & Eles estavam nadando... & & & Garantia \\
\hline 83 & A13 & [Inaudível] & & & \\
\hline 84 & $\mathrm{P}$ & $\begin{array}{l}\text { Mas eles se movimentam por causa que a água tá se movimentando. Pra ser um ser } \\
\text { vivo, precisa se movimentar? }\end{array}$ & $\begin{array}{l}\text { Qualificar } \\
\text { Explorar }\end{array}$ & $\begin{array}{l}\text { Qualifica explicações } \\
\text { ou pontos de vista } \\
\text { Explora condições de } \\
\text { investigação }\end{array}$ & \\
\hline 85 & A15 & É semente? & & & \\
\hline 86 & $\mathrm{P}$ & Planta não é ser vivo? & Retomar & Retoma informações & \\
\hline 87 & An & É. & & & Refutação \\
\hline 88 & $\mathrm{P}$ & Ela se movimenta? & Retomar & Retoma informações & \\
\hline 89 & A15 & Não! & & & Refutação \\
\hline 90 & $\mathrm{P}$ & Ela não se movimenta. & Qualificar & $\begin{array}{l}\text { Qualifica explicações } \\
\text { ou pontos de vista }\end{array}$ & \\
\hline 91 & A14 & Quando passa o vento sobre as folhas... & & & \\
\hline 92 & $\mathrm{P}$ & $\begin{array}{l}\text { Não, quando passa o vento... ((professor P gesticula cabeça no sentido de contrariar } \\
\text { com a resposta do aluno A14)) Até uma cadeira pode cair com a força do vento. Um } \\
\text { papel no vento pode voar. }\end{array}$ & Qualificar & $\begin{array}{c}\text { Qualifica explicações } \\
\text { ou pontos de vista }\end{array}$ & \\
\hline 93 & $\mathrm{P}$ & $\begin{array}{l}\text { Olha só! [bate palmas] Ei! (...) Qual que é a pergunta que fiz no começo? Que a } \\
\text { cientista precisava saber? (...) Se nesse pote tem seres vivos ou não! Quem acha que } \\
\text { tem, levanta a mão? }\end{array}$ & Problematizar & Propõe um problema & \\
\hline 94 & An & Eu! & & & \\
\hline 95 & $\mathrm{P}$ & $\begin{array}{l}\text { Então quem levantou a mão vai ter que me dizer o porquê que acha que tem ser vivo } \\
\text { ali. }\end{array}$ & Explorar & Explora ponto de vista & \\
\hline 96 & A5 & [Inaudível] & & & \\
\hline 97 & A3 & Eu vi eles se mexendo ((aluno A3 move as mãos em sentidos contrários)) & & & Dado \\
\hline 98 & $\mathrm{P}$ & Cê viu eles se mexendo... & Explorar & $\begin{array}{l}\text { Explora condições de } \\
\text { investigação }\end{array}$ & \\
\hline
\end{tabular}




\begin{tabular}{|c|c|c|c|c|c|}
\hline 99 & A4 & Tio! Tio::: & & & \\
\hline 100 & $\mathrm{~A} 3$ & Assim, não tem nada se... & & & \\
\hline 101 & A15 & Oh tio, será que tem bactérias ali no pote? & & & \\
\hline 102 & $\mathrm{P}$ & Cê acha que tem bactéria ali? & Explorar & Explora ponto de vista & \\
\hline 103 & An & $(($ levanta a mão $))$ & & & \\
\hline 104 & $\mathrm{P}$ & Perai! Aonde que estavam as bactérias? & Retomar & Retoma dados & \\
\hline 105 & A3 & Da água. & & & \\
\hline 106 & $\mathrm{P}$ & As bolinhas... [Inaudível] & Retomar & Retoma dados & \\
\hline 107 & A13 & As bolinhas saíram... do liquido ali. As pedrinhas... & & & Dado \\
\hline 108 & $\mathrm{P}$ & Ele acha que ali são pedrinhas. & Retomar & Retoma dados & \\
\hline 109 & A13 & [Inaudível] & & & \\
\hline 110 & $\mathrm{P}$ & $\begin{array}{l}\text { Então, ali tem ser vivo? Você acha que não tem ser vivo. (...) Cê acha que tem? } \\
\text { ((apontando para aluno A3)). }\end{array}$ & Problematizar & Propõe um problema & \\
\hline 111 & A3 & O quê? & & & \\
\hline 112 & $\mathrm{P}$ & Ser vivo? Bactéria? & & & \\
\hline 113 & A6 & Eu não! & & & \\
\hline 114 & $\mathrm{P}$ & Não?! & & & \\
\hline 115 & A16 & $\begin{array}{l}\text { Não tem ser vivo! Porque eles não se mexem. Quantas vezes ele ia... ((aluno gesticula } \\
\text { com as mãos como se algo estivesse flutuando)). }\end{array}$ & & & $\begin{array}{c}\text { Conclusão } \\
\text { Garantia }\end{array}$ \\
\hline 116 & $\mathrm{P}$ & $\begin{array}{l}\text { Então tá! Olha só! Vamos pegar uma coisa aí que é se mexer. Psiu! Meninos. Tem } \\
\text { gente que tá confuso por quê? Porque acha que se mexer ou que não se mexer... Então } \\
\text { a primeira pergunta é assim: pra ser um ser vivo, tem que se movimentar? }\end{array}$ & Explorar & Explora ponto de vista & \\
\hline 117 & An & Não! & & & Refutação \\
\hline 118 & $\mathrm{P}$ & Qual o exemplo de um ser vivo que não se mexe? & Retomar & Retoma informações & \\
\hline 119 & A16 & ((Levanta a mão)) árvore. & & & Refutação \\
\hline 120 & $\mathrm{P}$ & Árvore! & Qualificar & $\begin{array}{l}\text { Qualifica variáveis, } \\
\text { objetos ou fenômenos }\end{array}$ & \\
\hline 121 & A17 & O cogumelo. & & & Refutação \\
\hline 122 & $\mathrm{P}$ & Muitas plantas. O cogumelo. & Qualificar & $\begin{array}{l}\text { Qualifica variáveis, } \\
\text { objetos ou fenômenos }\end{array}$ & \\
\hline 123 & A16 & Oh tio ((aponta para o P que está gravando a aula)) viu o que eu falei? & & & \\
\hline 124 & $\mathrm{P}$ & Então não é porque está se movimentando ou tá parado... & Qualificar & $\begin{array}{l}\text { Qualifica explicações } \\
\text { ou pontos de vista }\end{array}$ & \\
\hline 125 & A16 & Eu sei que tem aquele negócio da doença... [Inaudível] & & & \\
\hline 126 & A6 & Oh tio, é que antes... & & & \\
\hline
\end{tabular}




\begin{tabular}{|c|c|c|c|c|c|}
\hline 127 & A17 & [Inaudível] & & & \\
\hline 128 & $\mathrm{P}$ & $\begin{array}{l}\text { Então, peraí. Então, não é porque uma coisa tá se movendo que é ser vivo. Não é isso! } \\
\text { Tem coisas que não são vivas e se movem. O carro se move. Uma folha no vento se } \\
\text { move. Não são vivos. }\end{array}$ & $\begin{array}{l}\text { Qualificar } \\
\text { Sintetizar }\end{array}$ & $\begin{array}{l}\text { Qualifica explicações } \\
\text { ou pontos de vista } \\
\text { Sintetiza informações }\end{array}$ & \\
\hline 129 & A16 & Deveria... [Inaudível] & & & \\
\hline 130 & $\mathrm{P}$ & Tem coisas que se não se movem e são seres vivos. & Qualificar & $\begin{array}{l}\text { Qualifica explicações } \\
\text { ou pontos de vista }\end{array}$ & \\
\hline 131 & A16 & É a árvore. & & & Refutação \\
\hline 132 & $\mathrm{P}$ & Por exemplo, as plantas. Os cogumelos. Árvores são plantas. & $\begin{array}{l}\text { Retomar } \\
\text { Qualificar }\end{array}$ & $\begin{array}{l}\text { Retoma informações } \\
\text { Qualifica variáveis, } \\
\text { objetos ou fenômenos }\end{array}$ & \\
\hline 133 & A16 & ((aluno A16 aponta para área onde tem plantas $))$ & & & \\
\hline 134 & $\mathrm{P}$ & $\begin{array}{l}\text { Elas não saem andando por aí. Então, isso daí não é suficiente. Por que vocês viram } \\
\text { as coisas se mexendo? Porque a água não tinha secado... }\end{array}$ & Qualificar & $\begin{array}{l}\text { Qualifica explicações } \\
\text { ou pontos de vista } \\
\text { Qualifica contexto de } \\
\text { investigação }\end{array}$ & \\
\hline 135 & A16 & Eu sei, porque a água tava debaixo do espelho... & & & \\
\hline 136 & $\mathrm{P}$ & $\begin{array}{l}\text { Ficou a água mexendo ((professor move as duas mãos juntas para a direita e para a } \\
\text { esquerda)) a lamínula, ficando indo pra um lado e pro outro e assim se deu o } \\
\text { movimento. }\end{array}$ & Qualificar & $\begin{array}{l}\text { Qualifica contexto de } \\
\text { investigação }\end{array}$ & \\
\hline 137 & A16 & Mas quando a gente foi ver... & & & \\
\hline 138 & $\mathrm{P}$ & Se eu deixar secar, se eu deixar secar completamente, não vai ter movimento. Tá? & Qualificar & $\begin{array}{l}\text { Qualifica contexto de } \\
\text { investigação }\end{array}$ & \\
\hline 139 & A4 & ((levanta a mão)) & & & \\
\hline 140 & $\mathrm{P}$ & Mas e aí (...) Como é que é seu nome? ((apontando para A14)) & & & \\
\hline 141 & A4 & Eu? & & & \\
\hline 142 & $\mathrm{P}$ & O de trás ((gesticula o indicador em movimento circular)). & & & \\
\hline 143 & A14 & A14 & & & \\
\hline 144 & $\mathrm{P}$ & $\begin{array}{l}\text { A14, A14. A14 falou uma coisa interessante ali. Ele acha que aquelas bolinhas são o } \\
\text { quê? }\end{array}$ & Retomar & Retoma informações & \\
\hline 145 & A14 & Bactéria? & & & Garantia \\
\hline 146 & $\mathrm{P}$ & O nome...que você já ouviu em algum lugar... & Retomar & Retoma informações & \\
\hline 147 & A14 & Células. & & & Garantia \\
\hline 148 & $\mathrm{P}$ & Células. & Qualificar & $\begin{array}{l}\text { Qualifica variáveis, } \\
\text { objetos ou fenômenos }\end{array}$ & \\
\hline
\end{tabular}




\begin{tabular}{|c|c|c|c|c|c|}
\hline 149 & $\mathrm{~A} 6$ & Quê é isso? & & & \\
\hline 150 & $\mathrm{P}$ & Eu já vou falar. & & & \\
\hline 151 & A3 & Eu sei o que é. & & & \\
\hline 152 & A4 & ((levanta a mão)) & & & \\
\hline 153 & A3 & A gente já estudou isso na sala. & & & \\
\hline 154 & $\mathrm{P}$ & Cês já estudaram isso? & Retomar & Retoma informações & \\
\hline 155 & A6 & Será? & & & \\
\hline 156 & $\mathrm{P}$ & O que é uma célula? & Retomar & Retoma conceito & \\
\hline 157 & A16 & É um negócio que tem na planta. & & & Garantia \\
\hline 158 & $\mathrm{P}$ & $\begin{array}{l}\text { É um negócio que tem na planta. (...) Energia da planta? Quem se lembra de mais } \\
\text { alguma coisa? }\end{array}$ & $\begin{array}{l}\text { Retomar } \\
\text { Explorar }\end{array}$ & $\begin{array}{l}\text { Retoma conceito } \\
\text { Explora ponto de vista }\end{array}$ & \\
\hline 159 & A15 & É um negócio bem pequeno. & & & Garantia \\
\hline 160 & $\mathrm{P}$ & Tem no corpo da gente também? & Explorar & Explora ponto de vista & \\
\hline 161 & An & Tem! & & & Garantia \\
\hline 162 & A3 & Tem célula no nosso corpo. & & & Garantia \\
\hline 163 & A16 & É. & & & \\
\hline 164 & A17 & [Inaudível] & & & \\
\hline 165 & $\mathrm{P}$ & Como que é o formato de uma célula? & Explorar & Explora ponto de vista & \\
\hline 166 & A15 & Circular. & & & Dado \\
\hline 167 & An & ((levanta a mão)) & & & \\
\hline 168 & $\mathrm{P}$ & Se você fosse capaz de desenhar uma célula pra mim... & & & \\
\hline 169 & A16 & Oh tio...oh tio... & & & \\
\hline 170 & $\mathrm{P}$ & Pera um pouquinho! & & & \\
\hline 171 & A16 & Oh tio! & & & \\
\hline 172 & $\mathrm{P}$ & Peeera! & & & \\
\hline 173 & A17 & [Inaudível] & & & \\
\hline 174 & $\mathrm{P}$ & Tem que ter! & & & \\
\hline 175 & A16 & Tio... & & & \\
\hline 176 & $\mathrm{P}$ & Se fossem desenhar uma célula pra mim, como seria o formato dela? & Explorar & Explora ponto de vista & \\
\hline 177 & A17 & ((levanta a mão)) eu sei tio, eu sei. Meio assim... & & & \\
\hline 178 & A3 & Redonda! & & & Dado \\
\hline 179 & $\mathrm{P}$ & Redonda! & Qualificar & $\begin{array}{l}\text { Qualifica variáveis, } \\
\text { objetos ou fenômenos }\end{array}$ & \\
\hline 180 & A7 & Quadrada! & & & Dado \\
\hline 181 & $\mathrm{P}$ & Quadrada! & Qualificar & Qualifica variáveis, & \\
\hline
\end{tabular}




\begin{tabular}{|c|c|c|c|c|c|}
\hline & & & & objetos ou fenômenos & \\
\hline 182 & A17 & $(($ mostra um desenho para $\mathrm{P}))$ & & & \\
\hline 183 & $\mathrm{P}$ & $\begin{array}{l}\text { Isso é o DNA que tá dentro da célula. Então, como é que você desenharia uma célula } \\
\text { pra mim? }\end{array}$ & $\begin{array}{l}\text { Qualificar } \\
\text { Explorar }\end{array}$ & $\begin{array}{l}\text { Qualifica variáveis, } \\
\text { objetos ou fenômenos } \\
\text { Explora ponto de vista }\end{array}$ & \\
\hline 184 & A3 & Redonda! & & & Dado \\
\hline 185 & A16 & Tio... ((levanta a mão)) & & & \\
\hline 186 & $\mathrm{P}$ & Redonda? Ou quadrada? & Explorar & Explora ponto de vista & \\
\hline 187 & A16 & [Inaudível] & & & \\
\hline 188 & $\mathrm{P}$ & Triangular? Então, é o quê? & Explorar & Explora ponto de vista & \\
\hline 189 & A16 & Quando a gente tira do sangue... & & & \\
\hline 190 & $\mathrm{P}$ & $\begin{array}{l}\text { Se a gente tirar nosso sangue e colocar aqui vai ver células. Se a gente esfregar o } \\
\text { cotonete na bochecha e colocar ali vai haver células. Porque todos os lugares (...) em } \\
\text { todos os lugares de nosso corpo (...). Oh! ((professor P bate palmas)) Psiu! Em todos } \\
\text { os lugares de nosso corpo tem células. Plantas têm células... }\end{array}$ & $\begin{array}{l}\text { Qualificar } \\
\text { Sintetizar }\end{array}$ & $\begin{array}{l}\text { Qualifica variáveis, } \\
\text { objetos ou fenômenos } \\
\text { Sintetiza informações }\end{array}$ & \\
\hline 191 & An & Tem. & & & Garantia \\
\hline 192 & $\mathrm{P}$ & $\begin{array}{l}\text { Em todos os lugares da planta tem células. Todos os seres vivos têm células. Então, } \\
\text { uma casa não é construída de vários tijolos? }\end{array}$ & $\begin{array}{l}\text { Qualificar } \\
\text { Sintetizar }\end{array}$ & $\begin{array}{l}\text { Qualifica variáveis, } \\
\text { objetos ou fenômenos } \\
\text { Sintetiza informações }\end{array}$ & \\
\hline 193 & An & Sim! & & & Garantia \\
\hline 194 & $\mathrm{P}$ & $\begin{array}{l}\text { Se você monta um brinquedo em peça de lego, então não tem várias peças menores } \\
\text { que cabem em uma peça maior? }\end{array}$ & $\begin{array}{l}\text { Qualificar } \\
\text { Explorar }\end{array}$ & $\begin{array}{l}\text { Qualifica variáveis, } \\
\text { objetos ou fenômenos } \\
\text { Explora ponto de vista }\end{array}$ & \\
\hline 195 & A3 & É. & & & \\
\hline 196 & A15 & Sim. & & & \\
\hline 197 & $\mathrm{P}$ & $\begin{array}{l}\text { Quais que são as menores unidades que, quando elas se juntam, elas formam seres } \\
\text { vivos? Células. Então, a unidade, a unidade fundamental, a unidade que, se eu dividir, } \\
\text { dividir, dividir o ser vivo, separar o ser vivo, separar, separar, separar... Vai sobrar o } \\
\text { quê? Um monte de células. }\end{array}$ & $\begin{array}{l}\text { Qualificar } \\
\text { Sintetizar }\end{array}$ & $\begin{array}{l}\text { Qualifica variáveis, } \\
\text { objetos ou fenômenos } \\
\text { Sintetiza explicações }\end{array}$ & \\
\hline 198 & A4 & Ah::: então se eu fizer isso, ficará menor! & & & \\
\hline 199 & $\mathrm{P}$ & Se eu pegar as células e irem se juntando... & Qualificar & $\begin{array}{l}\text { Qualifica variáveis, } \\
\text { objetos ou fenômenos }\end{array}$ & \\
\hline 200 & A16 & E se elas forem se juntando vão ficando maiores... & & & \\
\hline 201 & $\mathrm{P}$ & $\begin{array}{l}\text { Vão formando outras coisas que vão formando as outras partes dos seres vivos. Só } \\
\text { que tem ser vivo, tem ser vivo que é formado de uma única ((levanta o dedo } \\
\text { indicador)) célula. Nós temos milhões. Porque nós somos grandes e cheios de órgãos. }\end{array}$ & $\begin{array}{l}\text { Qualificar } \\
\text { Sintetizar }\end{array}$ & $\begin{array}{l}\text { Qualifica variáveis, } \\
\text { objetos ou fenômenos } \\
\text { Sintetiza explicações }\end{array}$ & \\
\hline
\end{tabular}




\begin{tabular}{|c|c|c|c|c|}
\hline & & $\begin{array}{l}\text { Tem o sistema respiratório, tem o sistema circulatório, digestório, então tem milhares } \\
\text { de células, cada uma com sua função, cada uma com um formato. Então tem célula } \\
\text { redonda? Tem célula redonda. Nosso amigo ((vem em direção ao aluno A17)) disse } \\
\text { se tem célula quadrada? Tem célula quadrada. E de todos os formatos. Dependendo... }\end{array}$ & Retomar & Retoma informações \\
\hline 202 & A13 & [Inaudível] & & \\
\hline 203 & $\mathrm{P}$ & $\begin{array}{l}\text { Talvez. Dependendo da função que ela tenha ela vai ganhando forma geométrica. Tá? } \\
\text { Só que tem ser vivo ((levanta o dedo indicador)) que tem uma única célula. Quem } \\
\text { que imagina que tenha uma única célula? }\end{array}$ & $\begin{array}{l}\text { Qualificar } \\
\text { Sintetizar } \\
\text { Explorar }\end{array}$ & $\begin{array}{l}\text { Qualifica variáveis, } \\
\text { objetos ou fenômenos } \\
\text { Sintetiza explicações } \\
\text { Explora ponto de vista }\end{array}$ \\
\hline 204 & A16 & ((levanta o dedo)) eu. & & \\
\hline 205 & A4 & O plâncton. & & \\
\hline 206 & A16 & O cachorro. & & \\
\hline 207 & $\mathrm{P}$ & Cachorro tem milhões de células. & Qualificar & $\begin{array}{l}\text { Qualifica variáveis, } \\
\text { objetos ou fenômenos }\end{array}$ \\
\hline 208 & A16 & ((levanta o dedo)) Ah, passarinho! & & \\
\hline 209 & $\mathrm{P}$ & $\begin{array}{l}\text { Tem que ser muito menor que passarinho. Uma única célula... Eu consigo ver uma } \\
\text { única célula só com os meus olhos? }\end{array}$ & $\begin{array}{l}\text { Qualificar } \\
\text { Explorar }\end{array}$ & $\begin{array}{l}\text { Qualifica variáveis, } \\
\text { objetos ou fenômenos } \\
\text { Explora ponto de vista }\end{array}$ \\
\hline 210 & An & Não! & & \\
\hline 211 & $\mathrm{P}$ & $\begin{array}{l}\text { Então o ser vivo tem que ser muito pequeno. O carrapato eu consigo ver com o meu } \\
\text { olho? }\end{array}$ & $\begin{array}{l}\text { Qualificar } \\
\text { Explorar }\end{array}$ & $\begin{array}{l}\text { Qualifica variáveis, } \\
\text { objetos ou fenômenos } \\
\text { Explora condições de } \\
\quad \text { investigação }\end{array}$ \\
\hline 212 & $\mathrm{~A} 4, \mathrm{~A} 15$ & Sim! & & \\
\hline 213 & $\mathrm{P}$ & $\begin{array}{l}\text { Então tem várias células. E qual o ser vivo que eu não consigo ver com os meus } \\
\text { olhos? }\end{array}$ & $\begin{array}{l}\text { Qualificar } \\
\text { Explorar }\end{array}$ & $\begin{array}{l}\text { Qualifica variáveis, } \\
\text { objetos ou fenômenos } \\
\text { Explora condições de } \\
\text { investigação }\end{array}$ \\
\hline 214 & A18 & Formiga. & & \\
\hline 215 & $\mathrm{P}$ & Eu não consigo ver formiga somente com meus olhos? & $\begin{array}{l}\text { Qualificar } \\
\text { Explorar }\end{array}$ & $\begin{array}{l}\text { Qualifica variáveis, } \\
\text { objetos ou fenômenos } \\
\text { Explora condições de } \\
\text { investigação }\end{array}$ \\
\hline 216 & A3 & Ah lógico que dá pra ver. & & \\
\hline 217 & A16 & ((levanta a mão)) eu sei, eu sei... Aquele negócio pequenininho... & & \\
\hline
\end{tabular}




\begin{tabular}{|c|c|c|c|c|c|}
\hline 218 & $\mathrm{P}$ & Micróbio. O que é que é um micróbio? & $\begin{array}{l}\text { Qualificar } \\
\text { Explorar }\end{array}$ & $\begin{array}{l}\text { Qualifica variáveis, } \\
\text { objetos ou fenômenos } \\
\text { Explora ponto de vista }\end{array}$ & \\
\hline 219 & A15 & Germe! & & & \\
\hline 220 & A16 & Germes. & & & \\
\hline 221 & $\mathrm{P}$ & Germes. Bactéria. & $\begin{array}{l}\text { Qualificar } \\
\text { Retomar }\end{array}$ & $\begin{array}{c}\text { Qualifica variáveis } \\
\text { objetos ou fenômenos } \\
\text { Retoma conceito }\end{array}$ & \\
\hline 222 & A4 & É. E o que mais? & & & \\
\hline 223 & $\mathrm{P}$ & Tem alguns seres vivos, oh, psiu:: ((bate palmas)). & & & \\
\hline 224 & A16 & Esquilo. & & & \\
\hline 225 & $\mathrm{P}$ & $\begin{array}{l}\text { Esquilo tem várias. Pra ter uma única célula, você sabe que cada bolinha que vocês } \\
\text { viram no microscópio? Cada bolinha... }\end{array}$ & $\begin{array}{l}\text { Qualificar } \\
\text { Retomar }\end{array}$ & $\begin{array}{l}\text { Qualifica variáveis, } \\
\text { objetos ou fenômenos } \\
\text { Retoma dados }\end{array}$ & \\
\hline 226 & A16 & É célula! & & & Garantia \\
\hline 227 & $\mathrm{P}$ & Um acha que é pedra, outro acha que é bactéria... & Retomar & Retoma informações & \\
\hline 228 & A16 & É célula. & & & Garantia \\
\hline 229 & $\mathrm{P}$ & Cada bolinha dessa, cada uma, é uma célula. & Sintetizar & Sintetiza informações & \\
\hline 230 & A3 & Que tá na água? & & & \\
\hline 231 & $\mathrm{P}$ & Que tá na água que eu tinha colocado no pote. As células estão nadando na água. & Sintetizar & Sintetiza informações & \\
\hline 232 & A13 & Concordo! & & & \\
\hline 233 & $\mathrm{P}$ & Cada bolinha... & & & \\
\hline 234 & A16 & Contém água com gelo... & & & \\
\hline 235 & $\mathrm{P}$ & Não. Contém água dentro da célula. Eu peguei o material da pesquisadora... & Retomar & Retoma informações & \\
\hline 236 & A3 & E o produto que tem a célula... & & & \\
\hline 237 & $\mathrm{P}$ & $\begin{array}{l}\text { Eu peguei esse material na água e misturei. Nesse material aqui ó, tem ser vivo. } \\
\text { Porque eu vi um monte de células. Se eu pegar esse e pingar na lâmina vai ter só } \\
\text { água. Pode até ter ser vivo ali, mas muito menos do que cês viram ali. (...) Se eu } \\
\text { pegar o material daqui, pinguei aqui e vi muitas células, cada célula aqui é um } \\
\text { microrganismo. Eu não sei ainda se é bactéria. Pode ser um fungo. A gente vai ter que } \\
\text { fazer outros experimentos para descobrir. Mas é um ser vivo cada vez que eu ver uma } \\
\text { bolinha, que é uma célula. E essa célula é um ser vivo. Nós somos seres vivos com } \\
\text { muitas células. }\end{array}$ & $\begin{array}{l}\text { Retomar } \\
\text { Qualificar }\end{array}$ & $\begin{array}{c}\text { Retoma dado } \\
\text { Retoma informações } \\
\text { Qualifica contexto de } \\
\text { investigação } \\
\text { Qualifica explicações } \\
\text { ou pontos de vista } \\
\text { Sintetiza explicações }\end{array}$ & \\
\hline 238 & A16 & Eu sei por quê. & & & \\
\hline 239 & $\mathrm{P}$ & Mas esses vistos na lâmina são seres vivos que são formados por uma célula. Então & Qualificar & Qualifica variáveis, & \\
\hline
\end{tabular}




\begin{tabular}{|c|c|c|c|c|}
\hline & & vocês viram o quanto de bolinhas que tinha ali? Aquilo ali é um monte de células. & $\begin{array}{l}\text { Retomar } \\
\text { Sintetizar }\end{array}$ & $\begin{array}{l}\text { objetos ou fenômenos } \\
\text { Retoma dado } \\
\text { Sintetiza explicações }\end{array}$ \\
\hline 240 & A15 & Oh tio... [Inaudível] sabe aonde tem muito micróbio? No asilo. & & \\
\hline 241 & A4 & [Inaudível] & & \\
\hline 242 & $\mathrm{P}$ & $\begin{array}{l}\text { Nosso colega fez uma pergunta legal. Quando você vê um vídeo na televisão, de } \\
\text { alguém olhando no microscópio, ou uma foto em um livro, a foto de um microscópio, } \\
\text { uma imagem de um microscópio, normalmente as coisas são muito coloridas. Quando } \\
\text { você olha uma célula em um livro, o desenho de uma célula, ela é toda colorida. } \\
\text { Então, o contorno dela tá de uma cor, o miolo dela tem outro, aí tem um monte de } \\
\text { estruturas que fazem essa célula... ((movimenta os dedos indicadores em círculos)) } \\
\text { porque a célula precisa se alimentar. }\end{array}$ & Retomar & Retoma informações \\
\hline 243 & A16 & O que é que tem lá dentro? & & \\
\hline 244 & $\mathrm{P}$ & $\begin{array}{l}\text { Lá tem um monte de coisas dentro da célula. Meio que as mesmas coisas que a gente. } \\
\text { Mas a gente tem que comer o alimento de um tamanho grande, digerir e absorver as } \\
\text { coisas que são pequenas. Uma célula vai conseguir se alimentar daquilo que já é } \\
\text { muito pequeno. Os nutrientes são muito pequenos. }\end{array}$ & Qualificar & $\begin{array}{c}\text { Qualifica explicações } \\
\text { ou pontos de vista }\end{array}$ \\
\hline 245 & A16 & Formiga? & & \\
\hline 246 & $\mathrm{P}$ & Não! Formiga é muito grande! & Qualificar & $\begin{array}{l}\text { Qualifica variáveis, } \\
\text { objetos ou fenômenos }\end{array}$ \\
\hline 247 & A16 & Pra ela? & & \\
\hline 248 & $\mathrm{P}$ & $\begin{array}{l}\text { Pra ela. Cês viram?! Eu tive que aumentar minha visão quarenta vezes. Pra ver uma } \\
\text { bolinha do tamanho de um pontinho. Eu aumentei quarenta vezes. A formiga, eu não } \\
\text { preciso aumentar nada. E eu já vejo ela deste tamanho ((apresenta tamanho com os } \\
\text { dedos polegar e indicador)). Aqui ((aponta para o frasco com a amostra)) eu vejo } \\
\text { aumentado quarenta vezes. Então isso aqui é quarenta vezes menor do que o pontinho } \\
\text { que eu faço no caderno. }\end{array}$ & Qualificar & $\begin{array}{l}\text { Qualifica variáveis, } \\
\text { objetos ou fenômenos }\end{array}$ \\
\hline 249 & A14 & Interessante. & & \\
\hline 250 & A17 & Vê menor? & & \\
\hline 251 & $\mathrm{P}$ & Menor. & Qualificar & $\begin{array}{l}\text { Qualifica variáveis, } \\
\text { objetos ou fenômenos }\end{array}$ \\
\hline 252 & A15 & $\begin{array}{l}\text { Ficaria menor que isso? ((aluno A15 mostra caderno para professor com imagem de } \\
\text { um ponto)). }\end{array}$ & & \\
\hline 253 & $\mathrm{P}$ & $\begin{array}{l}\text { Muito menor. Muito menor. Isso aqui eu consigo ver com meu olho. Eu vejo com } \\
\text { meu olho. }\end{array}$ & Qualificar & $\begin{array}{l}\text { Qualifica variáveis, } \\
\text { objetos ou fenômenos }\end{array}$ \\
\hline 254 & A16 & Se você tá vendo, é porque você enxerga. & & \\
\hline
\end{tabular}




\begin{tabular}{|c|c|c|c|c|}
\hline 255 & $P$ & $\begin{array}{l}\text { É porque você enxerga. Você consegue ver célula aqui? ((professor P mostra o frasco } \\
\text { contendo amostra para aluno A15)). }\end{array}$ & Explorar & Explora pontos de vista \\
\hline 256 & A16 & Não! & & \\
\hline 257 & $\mathrm{P}$ & Não! Aquelas bolinhas que você viu ali... & Retomar & Retoma dados \\
\hline 258 & A15 & Que bolinha é essa aqui? & & \\
\hline 259 & $\mathrm{P}$ & Essa bolinha é a bolinha da massa. & Qualificar & $\begin{array}{l}\text { Qualifica variáveis, } \\
\text { objetos ou fenômenos }\end{array}$ \\
\hline 260 & An & [Inaudível] ((conversa paralela)) & & \\
\hline 261 & $\mathrm{P}$ & $\begin{array}{l}\text { Isso é a massinha. Se eu pegar um potinho desse que você fez em seu caderno, aqui, } \\
\text { essa bolinha, amassar na lâmina, e aumentar quarenta vezes, eu vou ver centenas de } \\
\text { bolinhas. (...) Então, esse potinho tem seres vivos. Semana que vem a gente fala mais } \\
\text { deles. }\end{array}$ & $\begin{array}{l}\text { Qualificar } \\
\text { Sintetizar }\end{array}$ & $\begin{array}{l}\text { Qualifica variáveis, } \\
\text { objetos ou fenômenos } \\
\text { Sintetiza informações }\end{array}$ \\
\hline
\end{tabular}

